S T A T E OF I L L I N O I S

William G. Stratton, Governor

DEPARTMENT OF REGISTRATION AND EDUCATION

VERA M. BINks, Director

NATURAL H ISTORY SURVEY DIVISION

Harlow B. Mills, Chief

\title{
Natural Availability of Oak Wilt Inocula
}

\author{
E. A. C URL
}


STATEOF I L LINOIS

William G. Stratton, Goternor

DEPARTMENT OF REGISTRATION AND EDUCATION

VERA M. BINKS, Director

BOARD OF NATURAL RESOURCES AND CONSERVATION

VERA M. BiNks, Chairman

A. E. EMersox, Ph.D., Biology

L. H. THzaci, Ph.D., Forestry

ROBERT H. ANDERSON, B.S.C.E., Engineering

Waltek H. Newhouse, Ph.D., Geology Llovd Morey, B.A. B.Mus. C.P.A. LL.D. D.Sc. President of the Unirersily of Illinois

DELYTE IV. MokRIS. Ph.D., President of Southern Illinois Unitersity

\section{NATURAL, IIISTORY SURVEY DIVISION Urbana, Illinois}

SCIENTIFIC AND TECHNICAL, STAFF

HARLOW B. MILLS. Ph.D., Chief

Bessie B. EAst, M.S., Assistant to the Chief

Section of Econonic Entomology

GEORGE C. DECKER, Ph.D., Intomologist and llead

J. II. BiGGER, M.S., Entomologist

L. L. ENGLish, Ph.D., Entomologist

S. C. Cilander, B.S., A ssociale Entomologist

Willis N. BruCE, Ph.D., Associale Entomologist

Jorman C. Gaxion, Ph.D., Associale Enlomologist

JoHN M. WriGHT, Ph.D., Associate Entomologis

Paul Surasyt, Ph.D., Assistant Entomologist

W. H. LuCKMANN, M.S. Assis!ant Entomologist

Rovalp H. MEvEk, B.S., Assistant Entomologist

JohN W. MAtTEsoN, B.A.. Field A ssistant

Romert Snetsinger, M.S., Field A ssistant

Su'E E. Watklis, Technical Assistant

II. B. PETTY, Ph.D., Extension Specialist in Entomolog $y^{*}$

STEYexiox MOORE, III, Ph.D., Extension Specialist in Entomology*

JOHN ARTHUR LOWE, B.S., Research Assistant*

Mollax RaO, M.S., Research A ssistanl*

Clarexce E. WHite, B.S., Research Assistant*

Loulse ZiNGroxe, B.S., Research Assistant*

Section of Faunistic Surveys and Insect identification

H. H. Ross, Ph.D., Systematic Entcmologist and llead

Milton W. Sanderson, Ph.D., Associale Taxonomist

Lewis J. Staxward, Jk., Ph.D., Assistant Taxonomist

Pullip W. SMitil, Ph.D., Assistant Taxonomist

LEONORA K. GLOYD, M.S. Labara'ory A ssistant

THomas E. MOORE, M.S., Technical A ssistant

Baribara Gutowsky, M.A., Technical Assistant

\section{Section of Aquatic Biology}

George W. Bennetr, Ph.D., Aqualic Biologis! and llead

Wirliam C. Starkett, Ph.D., Associale Aqualic Biologist

R. WT. LarimorE. Ph.D., Associale Aqualic Biologist

Donald F. Hansen, Ph.D., Assistant Aqualic Biologist

ROBERT D. CROMPTON, Field Assistant

l.EONARD DURHA.M. M.S.. Research Assistant*

Willias F. Curbers, B.S., Technical Assistanl*
Section of Applied Botany and Plant Patholosy

J. Cedric Carter, Ph.D., Plant Palhologist and II ead

J. L. Forsberg, Ph.D., Associale Plant Pa. thologist

G. H. Boewe, M.S., Assistant Plant Pathologist R. J. Campana, Ph.D., Assislant Plant Palhologist

I. R. Schnember, Ph.D., Assistant Plant Pathologist

E. B. Himelick, M.S., Assistant Plant Pathologist ROBERT A. EVERs, Ph.D., Assistant Bolanist Rovenia F. Fitz-Gerald, B.A., Technical Assistant

HARRY J. KRUEGER, B.S., Research Assistant

James D. Bilbruck, M.S., Research Assistant*

\section{Section of Game Research and Management}

T. G. Scotr, Ph.D., Game Specialist and Head RalPH E. YeatTer, Ph.D., Game Specialist

F. C. Bellrose, B.S., Associate Game Specialis! H. C. Hanson, M.S., A ssistant Game Specialist J. S. JORDAN, Ph.D." Assistant Game Technician RosS J. MILLER, M.S., Field Ecologist

Frances D. RoBbins, B.A., Technical Assislan!

VIrginia A. Whipple, Technical Assistant

JoHn M. Schilling, Field Assistont

William B. ROBERTSON, JR., Ph.D., Research Assistant*

JAMES OPSAHL, M.S., Field Assistant*

Robert H. Brough, B.S., Field Assistant*

\section{Section of Publications and Public Relations}

JAMES S. AYARS, B.S., Technical Editor and Ilead BLANCIIE P. Young, B.A., Assistant Technical Editor

William E. Clark, Assistant Technical Pholographer

Milan Dobrovic, B.A., Technical Assistant

\section{Technical Library}

RUTH R. WARRICK, B.S., B.S.L.S., Technical Librarian

Oi.gA E. Griminger, B.A., Assistant Technical Librarian

Consultants: IIErietology, Hobart M. Smitu, Ph. D., A ssociale Professor of Zoology, Universily of Illinois; Parasitology, Norman D. Levine, Ph.D., Professor of lelerinary Parasilology and of Velerinary Research, Universily of Illinois.

* Employed on co-operative projects with one of several agencies: 1llinois Agricultural Extension Service, Illinois Department of Conservation, United States Army Surgeon General's Office, United States Department of Agriculture. United States Fish and Wildlife Service, United States Public Health Service, and others.

This puper is a contribution from the Section of Applied Botany and Plant Pathology.

$$
(13164-4 \mathrm{M}-3-55)
$$

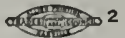




\section{CONTENTS}

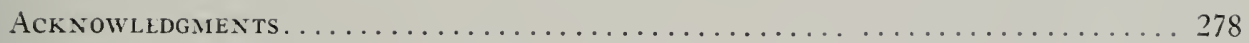

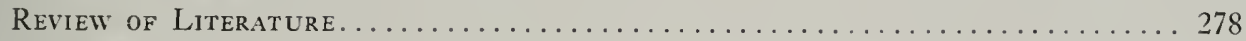

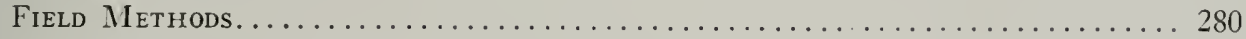

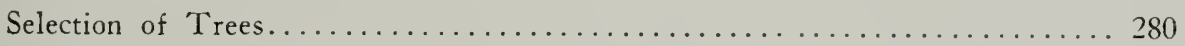

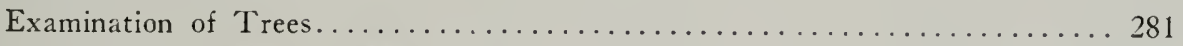

Classification of Mycelial Mats........................... 281

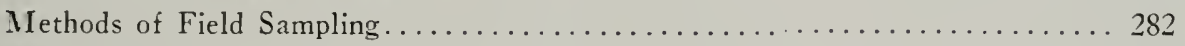

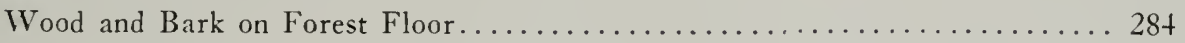

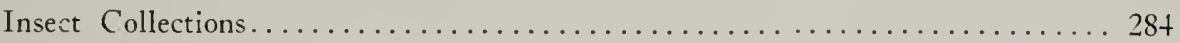

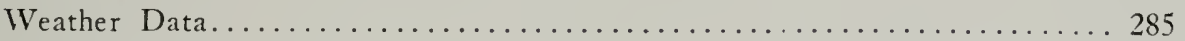

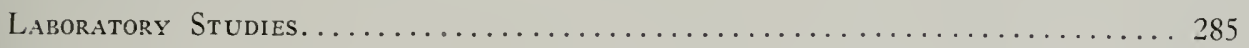

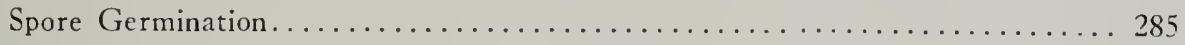

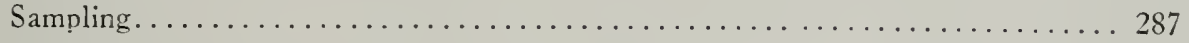

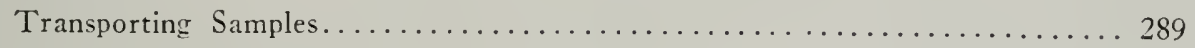

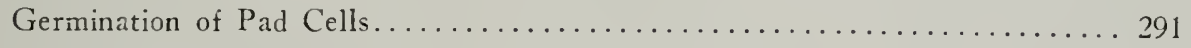

Production of Perithecia............................... 292

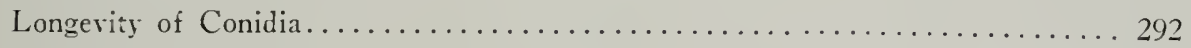

Treatment of Samples From Nature....................... 296

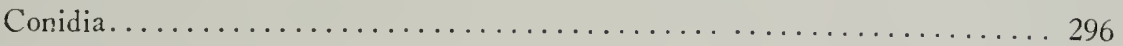

Perithecia and Ascospores............................ 296

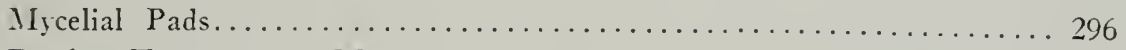

Further Treatment of Mats........................ 296

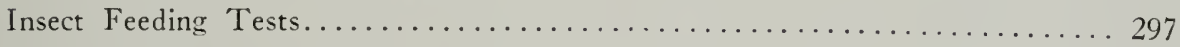

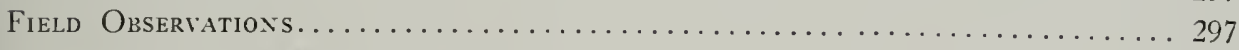

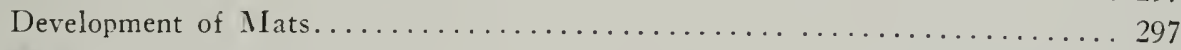

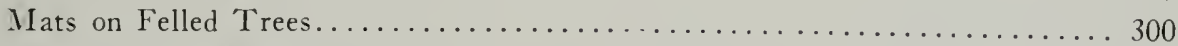

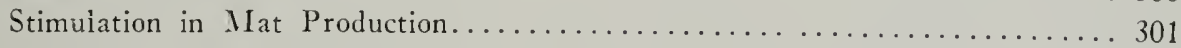

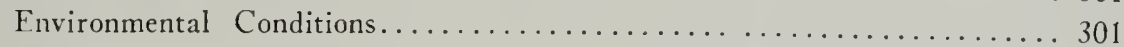

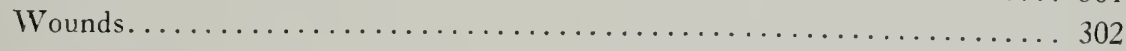

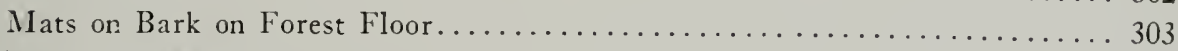

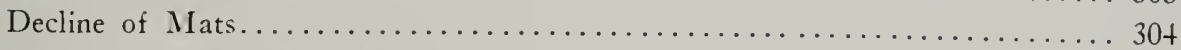

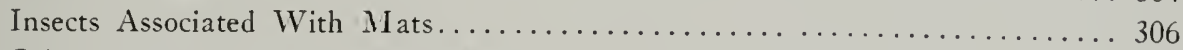

Other Agents Associated With Mats..................... 310

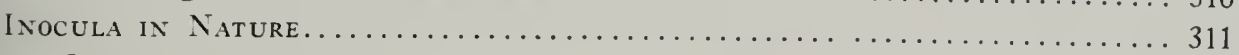

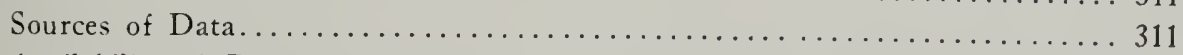

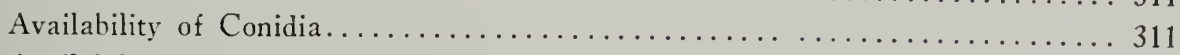

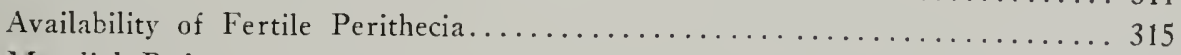

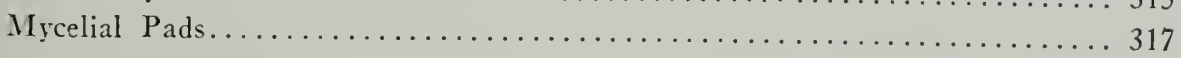

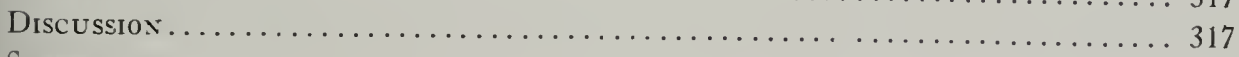

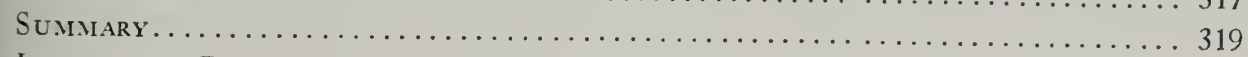

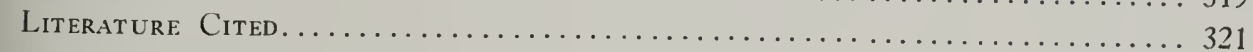




\section{Natural Availability of}

\section{Oak Wilt Inocula}

\section{E. A. C URL*}

I $\mathrm{N}$ the past 10 years, oak wilt, caused by Endoconidiophora fagacearum Bretz, has become increasingly important as a destroyer of oak trees in the eastern half of the United States. It was first described about 13 years ago as a fungus disease in Wisconsin (Anonymous 1942), but earlier reports of dying oaks indicate that it probably has been present there for the past 20 years.

The American oaks, which number about 300 species, are the most important group of hardwoods in North America, furnishing more native timber than any other related group of broadleaved trees (Finlay 1950). In 1948 the net volume of saw timber in Illinois totaled 10.3 billion board feet (King \& Winters 1952). The oak species total was 56 per cent of the net board-foot volume. White oak accounted for 21 per cent of the total, and black oak and northern red oak each made up about 10 per cent. The esthetic as well as the commercial value of oaks must be considered in evaluating the economic importance of oak wilt. Oaks are prized highly as both shade and ornamental trees.

No species of oak yet tested has shown immunity to oak wilt (Kuntz \& Riker $1950 \mathrm{~b})$. Other susceptible species of the family Fagaceae are Castanea mollissima Bl., Chinese chestnut; $C$. dentata Borkh., American chestnut; $C$. sativa Mill., European chestnut; Lithocarpus densiflorus Rehd., tanbark oak; and Castanopsis semperiirens Dudley, bush chinquapin (Bretz \& Long 1950, Bretz 1952a, Ernst \& Bretz

* Dr. E. A. Curl, now Assistant Plant Pathologist, Alabama Polytechnic Institute, Auburn, Alabama, was a Special Research Assistant with the Illinois Natural History Survey at the time he made the study reported here. The study was made possible through assistance provided by the Forest Preserve District of Cook County, River Forest, Illinois. This article is based upon a thesis submitted by the writer to the Graduate College. University of Illinois, Urbana, in partial fulfillment of the requirements for the degree of Doctor of Philosophy in Plant Pathology.
1953). Once infected, trees in the red oak group die rapidly, most of them within 6 weeks. Trees in the white oak group may die slowly over a period of 1 to 3 years.

Since 1942 oak wilt has been reported from 18 states. The results of aerial surveys (Fowler 1951, 1952, 1953) conducted by the United States Department of Agriculture, Division of Forest Pathology, since 1951 and various individual reports (Bretz 1949, Carter 1950b, 1952, Cummins 1949, Elmer et al. 1953, Fergus \& Morris 1950, French \& Christensen 1950, Strong 1951, Wysong 1949, Young \& Bart 1951) indicate a considerable increase in wilt in most of these states.

In Illinois the disease was first noticed in 1942 (Carter 1950a). By the end of 1952 it had been found in $5+$ of the 102 counties in the state. Most of the counties that are still free of the disease are located in areas where oak timber is not abundant.

The threat of oak wilt was recognized early in Wisconsin (Anonymous 1942. Henry et al. 194t) and in Iowa (Dietz \& Barrett 1946, Dietz \& Young 1948), where some of the first research on the disease was conducted between 1942 and 1948. In 1950 the National Oak Wilt Research Committee (Anonymous 1950) was organized at Memphis, Tennessee, for the purpose of supporting research programs in co-ordination with several universities and with the United States Department of Agriculture, Division of Forest Pathology. Such programs have now been developed in most of the states in which oak wilt is found.

The studies reported herein are intended mainly to supply information concerning the availability of oak wilt inocula and the relative importance of Illinois environmental conditions at different times of the year on the longevity of the causal 
fungus in nature. It seems that such informa:ion would be applicable in funding the means of spread of the disease beyond root graft distances and in selecting and developing effective control measures.

\section{ACKNOWLEDGMENTS}

'The author gratefully acknowledges the advice and guidance given him during the course of this study by the late Dr. Leo R. Tehon. While the study was being made, Dr. Tehon was Botanist and Head of the Section of Applied Botany and Plant Pathology, Illinois Natural History Survey, and Professor of P!ant Pathology, University of I!linois. 'The author wishes to express sincere appreciation to Dr. J. C. Carter, Plant Pathologist and present Head of the Section of Applied Botany and Plant Pathology of the Illinois Natural History Survey, for many helpful sugge:tions.

Others to whom the author wishes to give special recognition for contributions to the progress of the research and the preparation of the data are Mr. Noel B. ITysong, Chief Forester of the Forest Preserie District of Cook County; Mr. H. IV. Fox, Forester of the Sinnissippi Forest, Oregon, lllinois; Mr. R. F. Owens, Director of Parks, Peoria, Illinois; Mr. Ray R. Hamm, University of Illinois Photographic Laboratory; Dr. M. IV. Sanderson, Mr. James S. Ayars, Mr. IV. E. Clark, Mr. J. IV. Curfman, and Mrs. Rovenia M. Fitz-Gerald, all at the time of the study members of the Illinois Natura! History Survey staff.

\section{REVIEW OF LITERATURE}

A short time after the cause of oak wilt was established as a fungus (Anonymous 19+2), the conidial stage was named Chalara quercina by Henry (19+4). Later Bretz (1951, 1952b) succeeded in producing perithecia of the fungus in laboratory cultures and named this stage Endocontdiophora fagacearum. Symptoms of the disease have been adequately described by various workers (Henry \& Moses 19+3, Henry et al. 19+t, Henry \& Riker 19+7, Riker 1948, Young 1949).

In $19+9$ Kuntz \& Riker (1950a) demonstrated local spread of the disease from diseased to healthy trees through natural root grafts. The means by which the pathogen is transmitted beyond root graft distances has not been determined. While transmission through root grafts is highly important in parts of the Midwest where the disease has become well established, it does not appear to be the primary method of spread in states such as Pennsylvania (Fergus 1953) and Ohio (Young et al. 1953). There many isolated single-tree infections occur, indicating long-distance transmission by a spore-carrying vector.

For a decade following the identification of the causal fungus, the form of its fructification in nature was not known. In the summer and fall of 1951 Curl et al. (1952) discovered mycelial mats of $E_{n}$ doconidiophora fagacearum under the loose bark of diseased oak trees in Illinois. Endoconidia were present in large numbers on these mats. A little later Stessel \& Zuckerman (1953) discovered the ascigerous stage on mats in nature. Reports of endoconidium- and perithecium-bearing mats in other states (Barnett et al. 1952. Campbell \& French 1953, Morris \& Fergus 1952, Staley \& 'True 1952) indicate that this type of growth is common on wilt-killed oak trees. The implication of the possible importance of mats in serving as reservoirs of inoculum from which the unknown vector or vectors might spread the disease is readily understood. ( url et $a^{7}$. (1953) described the thick, sclerotiumlike pad that usually occupies the center of the mycelial mat, and they succeeded in producing a similar structure in laboratory cultures. Zuckerman \& Curl (1953) presented proof that the pad is a growth form of E. fagacearum and showed that single cells from laboratory-grown pad; were capable of continuing growth.

There are many physiological agents that affect the ability of fungus spores to germinate (Gottlieb 1950, Hawker 1950, Lilly \& Barnett 1951, Wolf \& IVolf 1947). Temperature and moisture have received more attention than other factors since they influence both the germinability of spores and the infection of the host. Many workers (Anderson et al. 1948, Heald \& Gardner 1914, Hea'd \& Studhalter 1915, Ling 1945, McCrea 1931, Rosen \& Weetman 1940) have shown that spores of various fungi usually remain 
viable longer under comparatively dry conditions than when kept moist, and the resistance of the spores to extremes of temperature is greater under dry conditions. Heat may affect reproduction by hastening the fungus to maturity (Lilly \& Barnett 1951).

Weather conditions are known to influence the incidence and relative prevalence of some plant diseases by influencing the availability of inoculum in the field. Ling (19+5), working with stripe rust of wheat in China, found that the amount and distribution of rainfall in late winter and spring are most important in determining rust epidemics. On the other hand, Anderson \& Rankin (1914) found that winter conditions have little effect on the viability of pycnospores of Endothia parasitica.

Wilkins (1938) stated that the age of the spore is probably the most important single factor influencing germination of ascospores of Ustulina zulgaris. By making collections of ascospores and conidia of $U$. $\tau$ 'ulgaris at intervals during the autumn and winter, he showed that the spores soon lose the power to germinate.

Henry (19+t) found that the oak wilt fungus grew best within a range of $2+$ to 28 degrees C. Young (19+9) found the optimum range to be 22 to 26 degrees $\mathrm{C}$. The optimum pH range for growth was found by Barnett \& Lilly (1952) and Young (1949) to lie between pH 5 and $\mathrm{pH} 7$, and to have limits at $\mathrm{pH} 3$ and $\mathrm{pH}$ 9. Young obtained maximum germination of conidia on agar of low dextrose content at 25 to 30 degrees C. Henry obtained best germination of conidia in 1.25 per cent malt solution at $2+$ degrees $C$. Little previous work has been reported dealing with germination requirements of ascospores of the fungus. Bretz (1952b) found that the ascospores germinated rapidly in 2 per cent dextrose solution at 25 degrees C. Stessel \& Zuckerman (1953), using ascospores taken in October from naturally occurring perithecia, obtained 30 per cent germination in 2 per cent dextrose solution at 25 degrees C.

The availability of oak wilt i-ocula under natural conditions and the effects of environmental conditions on longevity of the fungus have received some attention. McLaughlin \& True (1952) reported sur- rival of conidia of the oak wilt fungus for 173 dars on a glass surface when kept at 10 degrees C. in controlled low relative humidities. The survival period was much shorter at temperatures above 25 degrees C. Jewell (1953) found that low temperatures and low relative humidity farored the longevity of ascospores of the oak wilt fungus in ritro. Curl (1953) reported that the greatest concentration of viable, naturally occurring conidia and ascospores of the oak wilt fungus in Illinois was found during March, April, and May. Young (1949) demonstrated in Iowa that the fungus lives over winter in trees that become infected late in the summer. Young \& Spilker (1952) in Ohio failed to obtain the fungus from lumber that had been cut from wilt-killed oaks and piled during the summer, but isolated the fungus from large twigs, slabs, and stump wedges for a period of 3 weeks. Bretz \& Morison (1953) found that the survival of the oak wilt fungus in smalldiameter infected twig samples is relatively: short at temperatures of 20 to 25 degrees C. and above. Fergus (1953) reported the presence of mycelial mats of the fungus in nature in Pennsylvania from March through November, except in April and July: Morris \& Fergus (1952) noted the appearance of mats in early March and found them to be viable a month later. They also observed that two mats collected in May continued to produce new perithecia and ascospores for approximately 2 months when kept at $S$ degrees $C$. in a moist chamber. Campbell \& French (1953) found mycelial mats of the fungus in Minnesota in November after $21 \%$ months of drought.

The possible significance of mycelial mats of Endoconidiophora fagacearum in relation to transmission of the disease has been discussed by various workers. Curl et al. (1953) noted the presence of insects, which belonged to three families, beneath the bark of all mat-bearing trees examined in Illinois. Some larvae and adu'ts were seen in direct contact with the fungus. 'True et al. (1952) pointed out that mycelial mats might serve as natural reservoirs of oak wilt incculum. Craighead \& Morris (1952) observed more than 20 species of beetles, flies, and mites on mats of the oak wilt fungus. Morris \& Fergus 
(1952) in Pennsylvania found evidence of insect and rodent feeding on mycelial mats and pads. Himelick et al. (1953) in Illinois and Camphell \& French (1953) in Minnesota also reported considerable damage to the fungus pads by rodents. Birds and air currents have received little attention as possible agents of transmission.

'The only known practical controls for the oak wilt disease at the present time consist of interrupting root graft systems (Kuntz \& Riker 1950a) between healthy and infected trees and the practicing of sanitation and eradication (Dietz \& Barrett 1946, McNew \& Young 1948, Young et al. 1953) in oak wilt areas. Hoffman (1952), after investigating oak wilt chemotherapy, reported that several chemicals showed promise in their effectiveness against the pathogen under experimental conditions.

\section{FIELD METHODS}

\section{Selection of Trees}

IVilt-infected oak trees used in these studies were selected in late September, 1952. They consisted of 19 red oaks, Quercus borealis Michx. f., 9 black oaks, $Q$. velutina Lam., 1 bur oak, $Q$. macrocarpa Michx., and 1 white oak, $Q$. alba L., in five major oak wilt areas in the northern half of Illinois where oaks had been dying for several years. These areas were in the Forest Preserve District of Cook County near Chicago; a privately owned 100-acre tract in Ogle County $S$ miles south of Rockford; Sinnissippi Forest near Oregon; Detweiller Park at Peoria; and a privately owned 50 -acre tract, in Mason County, 10 miles east of Havana. For convenience the study areas will be referred to as the Chicago, Rockford, Sinnissippi Forest, Peoria, and Havana areas.

The total of 30 trees marked for study is a relatively small number compared with the number of wilted trees in all study areas. However, because of the thorough examination given each tree selected and the intensive study made of each mat collected or sampled, a larger number of trees could not be considered. Mycelial mats were collected from a few trees other than those marked for study. These were designated as miscellaneous mats, and they were added to the total number studied. Table 1 shows the kinds and diameters at breast height of trees that were selected for study in each area. The diameters ranged from 8 to 40 inches.

All trees selected for study had been naturally infected and had wilted in 1952 between June 12 and August 25. The initial examination of these trees showed that, in all but three, the trunks were completely sound, the only lethal sign being a slight brown characteristic streaking in the sap wood; the bark was very tight and appeared no different from that of healthy trees. The three trees mentioned above, designated as C-2, R-8, and R-9, were more advanced in their decline than the other trees. On these the bark was very

Table 1.-Wilt-killed oak trees chosen for study in five areas of Illinois. Size of trees is given in inches d.b.h.

\begin{tabular}{|c|c|c|c|c|c|c|c|c|c|c|c|c|c|c|}
\hline \multicolumn{3}{|c|}{$\begin{array}{c}\text { Chicago } \\
\text { Area }\end{array}$} & \multicolumn{3}{|c|}{$\begin{array}{l}\text { SiNNISSIPPI } \\
\text { ForEST }\end{array}$} & \multicolumn{3}{|c|}{$\begin{array}{c}\text { RocKFoRd } \\
\text { AREA }\end{array}$} & \multicolumn{3}{|c|}{$\begin{array}{c}\text { Peoria } \\
\text { Area }\end{array}$} & \multicolumn{3}{|c|}{$\begin{array}{c}\text { Havana } \\
\text { ArEa }\end{array}$} \\
\hline$\stackrel{u}{\longleftarrow}$ & 竞 &  & 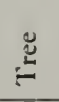 & 롤 & $\frac{\mathscr{U}}{\underline{E}}$ & ¿ & 足 & $\frac{\mathscr{d}}{\stackrel{\mathscr{E}}{E}}$ & Еّ & 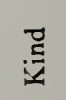 & $\underset{\Xi}{\stackrel{\mathscr{S}}{\varrho}}$ & Еँ & 记 & 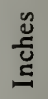 \\
\hline C-1 & Red & 36 & S-1 & Black & 12 & R-1 & Red & 20 & P-1 & Red & 10 & $\mathrm{H}-1$ & Black & 22 \\
\hline C-2 & Red & 22 & S-2 & Black & 16 & $\mathrm{R}-2$ & Red & 24 & P-2 & Red & 12 & $\mathrm{H}-2$ & Black & 20 \\
\hline C-3 & Red & 10 & S-3 & Black & 12 & R-3 & Red & 8 & P-3 & Red & 10 & $\mathrm{H}-3$ & Black & 24 \\
\hline C-4 & Red & 28 & S-4 & Black & 18 & $\mathrm{R}-4$ & Red & 14 & P-4 & Red & 15 & $\mathrm{H}-4$ & Black & 20 \\
\hline C- 5 & Bur & 12 & S-5 & Black & 14 & R-5 & Red & 12 & P-5 & Red & 24 & - & - & - \\
\hline C. 6 & White & 40 & - & - & - & R-6 & Red & 10 & P-6 & Red & 12 & - & - & - \\
\hline- & - & - & - & - & - & R-7 & Red & 10 & - & - & - & - & - & - \\
\hline - & - & - & - & - & - & R-8 & Red & 18 & - & - & - & - & - & - \\
\hline- & - & - & - & - & - & R-9 & Red & 22 & - & - & - & - & - & - \\
\hline
\end{tabular}




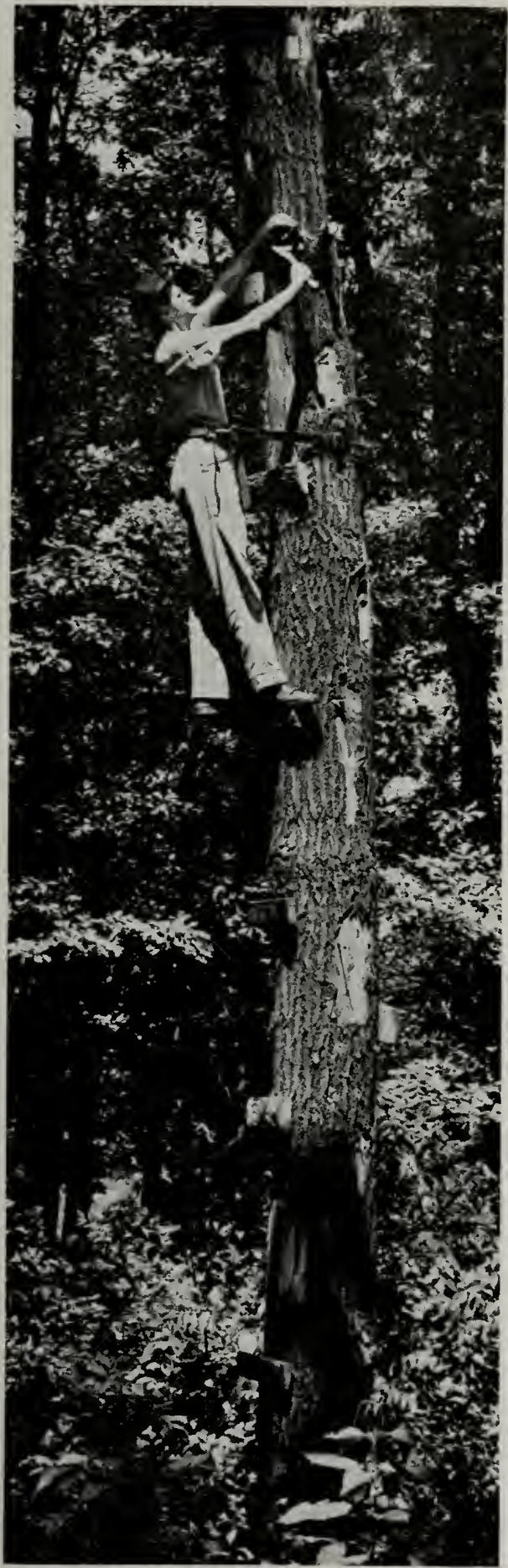

Fig. 1.-Examining a wilt-killed oak tree for mycelial mats. loose, and the condition of the wood appeared to be slightly beyond the optimum for mat development. These trees had wilted early in June.

\section{Examination of Trees}

Both standing and felled trees were studied. Five trees, four red oaks and one black oak, were felled to determine the ability of the fungus to fruit on felled timber. The remaining 25 trees were left standing so that a study might he made of their natural decline and the development and deterioration of mycelial mats under natural conditions.

Examination of the standing trees to heights of 20 to 55 feet was facilitated by ladders, fig. 1, constructed on the trunks with green oak slabs obtained from a sawmill. A lineman's safety belt, usually with a one-half-inch rope attached, was used as an added safety precaution. Climbing spurs were not used because of the treacherous nature of loose bark on dead trees. The ladders facilitated thorough examination of the entire main trunks of trees with relative ease and provided safe positions from which some of the lateral branches could be examined.

As excessive removal of bark might have caused infected trees to dry out before mats had a chance to form, these fruiting bodies of the fungus were located at first only by tapping the bark. This proved to be a surprisingly accurate method; in nearly every spot where the bark gave a dull, hollow sound when tapped, a mat was present. After trees have been dead for some time, of course, the entire trunk surface may produce a hollow sound. However, on trees that have reached this stage, few if any new mats will form. Many mats can be located merely by finding cracks in the bark, fig. 2, but these cracks are often so narrow that they are overlooked.

\section{Classification of Mycelial Mats}

The fruiting structure of the oak wilt fungus as it appears in nature consists of a light to dark grayish tan, sparse to dense mycelial felt, in the center of which lies a thick gelatinous pad. The mycelial felt with its central pad are referred to to- 


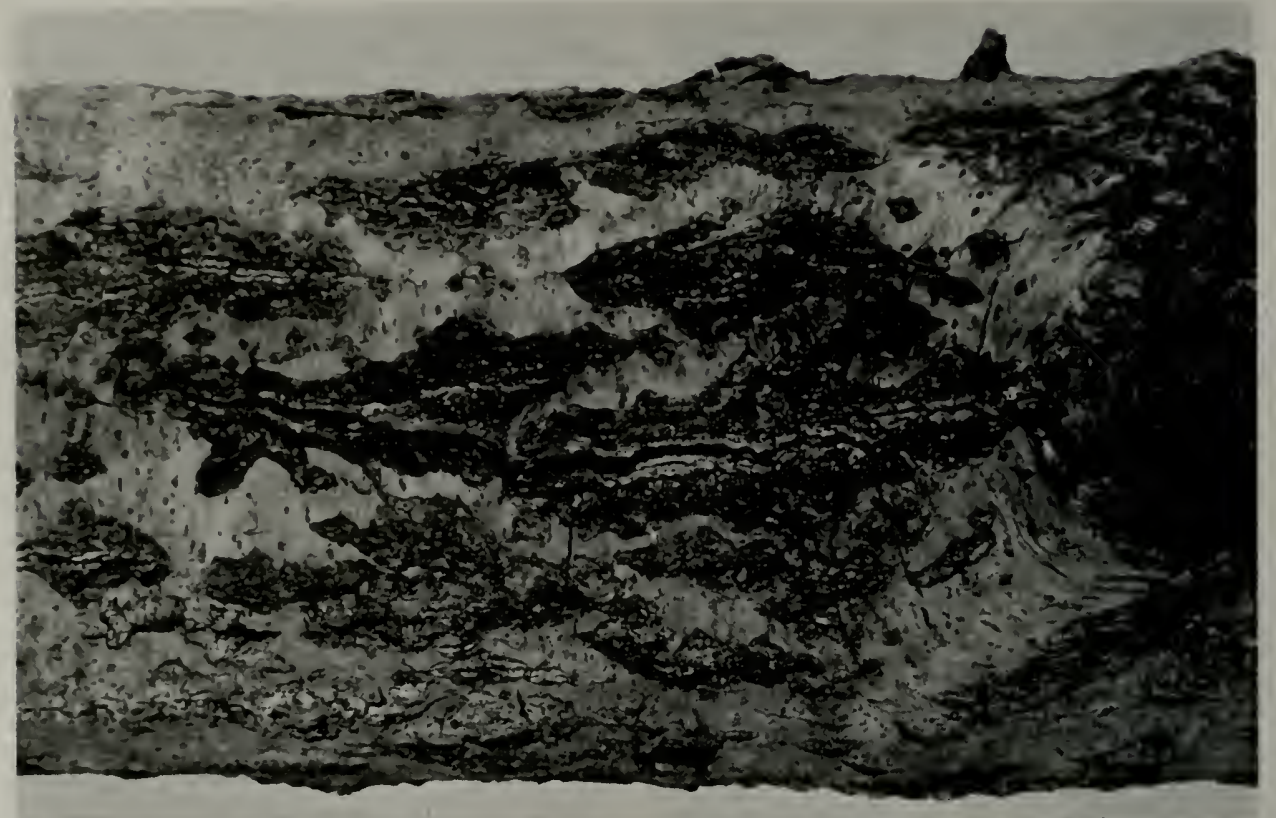

Fig. 2.-Typical crack in the bark of a wilt-killed oak trec. The crack resulted from growth of a fungus mat beneath the bark.

gether as a mycelial mat. The mat varies in size from 1 by $1 \mathrm{~cm}$. to 48 by $14 \mathrm{~cm}$. The central pad is elongated oval to elliptical, dull green to black in color, and has a daedaloid surface. It is pseudoparenchymatous in structure and is usually free of visible loose mycelium.

The following arbitrary classification, based on the stage of development or decline, was given to the mycelial mats examined in the study reported here. A mat of each class is shown in fig. 3 .

Class I. An immature or fresh mat, still in the rapid growth phase, with mycelium light tan or buff in color and having a firm, light- to dark-colored central pad which shows no sign of decline.

Class II. A mature mat, with mycelium and central pad beginning to darken slightly, the pad being firm and showing no definite signs of deterioration; vegetative growth appearing to have ceased or nearly ceased.

Class III. An aging mat, with mycelium and central pad becoming darker, the pad beginning to shrink or crack slightly from drying; showing other definite signs of aging but not deteriorating.
Class IV. A declining mat; mycelium and pad very dark or black, usually with only parts of the pad remaining intact; showing definite signs of rapid decline.

Class V. A deteriorating mat and pad, having lost nearly all consistency and having been reduced to a mass of dry, or wet, black soil-like material.

\section{Methods of Field Sampling}

Trees in the five study areas were thoroughly examined twice each month from October 1, 1952, to July 31, 1953. Some mats were examined and, after being sampled, were left on the trees. Others were removed from the trees and taken to the laboratory for study. Still others were tagged and left undisturbed for various periods of time. Metal picnic boxes equipped with ice containers were used for storing and transporting collected material from the field to the iaboratory. When the ice containers were kept filled with ice, the temperatures of the boxes were maintained below 16 degrees $C$., usually between 5 and 12 degrees, even during the hottest days of summer. The time 
that the material was kept in the iced picnic boxes between the point of collection and treatment in the laboratory never exceeded 5 days.

Mats were sampled on the trees in the following manner. After a mat had been located, a square or rectangular area extending slightly beyond the outer limit of the mat was marked off by driving a sharp chisel through the bark. The bark was then lifted easily and cleanly from the wood, and the mat beneath was exposed.
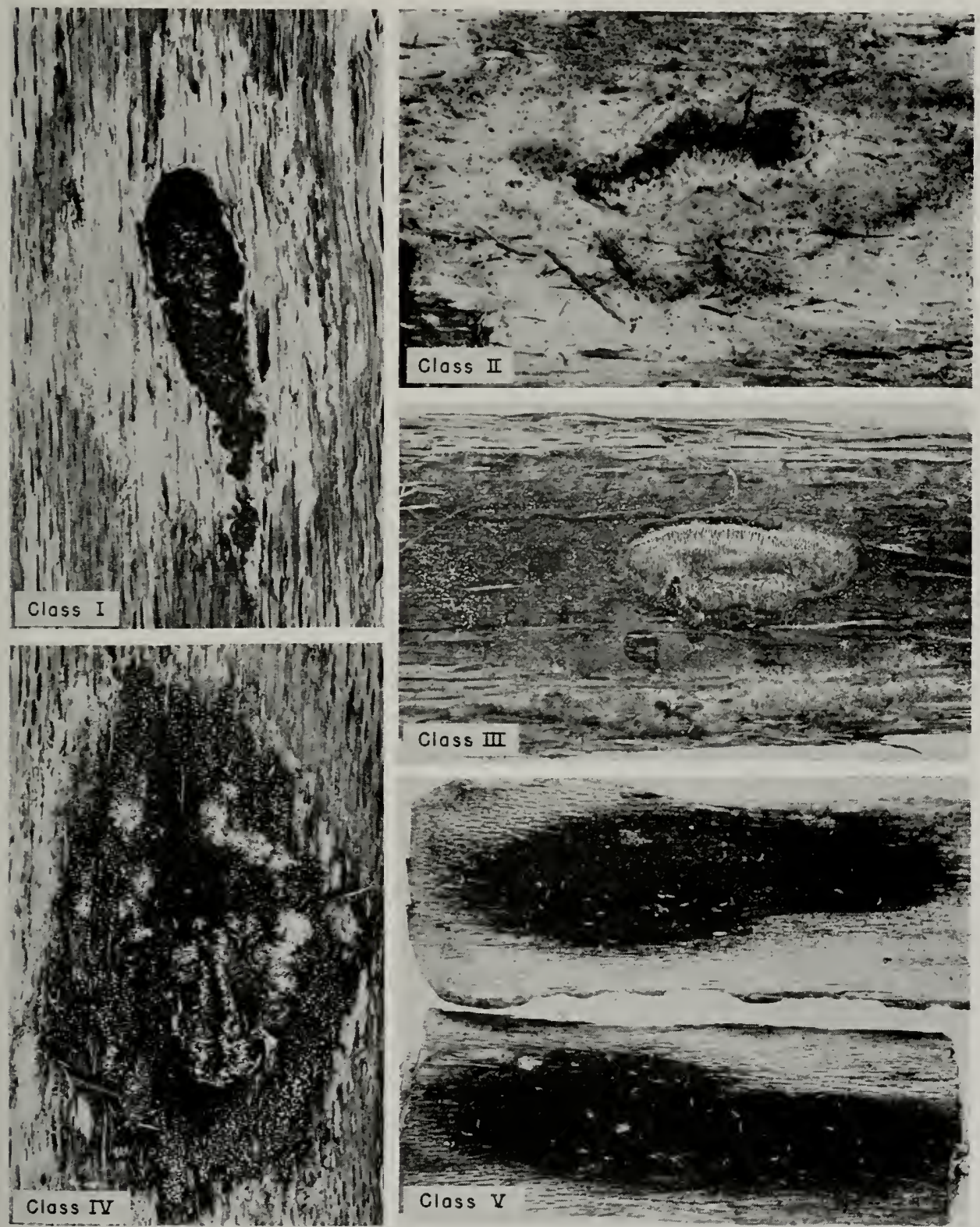

Fig. 3.-Mycelial mats of Endoconidiophora fagacearum representative of condition classes arbitrarily established on the basis of mat development and decline: class I, immature; class II, mature ; class III, aging; class IV, declining; class V, deteriorating. 
The size of the mat and its approximate distance from the ground were recorded. Three disks of mycelium, each $7 \mathrm{~mm}$. in diameter, were cut from the mat with a cork borer. One disk was taken from the periphery of the mat, one from the edge of the central pad, and a third from a point approximately halfway between the other two. When perithecia were present, four additional disks, each $7 \mathrm{~mm}$. in diameter, were taken with the cork borer from within the perithecium-producing "band" on four sides of the pad. Also, a small cross section of the central pad of each mat was taken with a knife. The cork borer and the knife blade were washed in alcohol and flamed before they were used in sampling a mat or pad.

The three mycelial disks were placed in a sterile, t-ounce glass bottle that contained moist filter paper. The perithecium samp!es taken from each mat were placed in the bottle with the mycelial disks from the same mat, but they were kept separated from the mycelium by folds in the filter paper. The pad samples from each mat were kept in a separate bottle for later determination of viability of inner cells. All bottles were stored in the iced picnic boxes for transportation to the laboratory. After samples had been taken from a mat, the bark was carefully returned to its original position and nailed down securely with small nails.

Whole mats were removed from trees with a chisel in such a manner that with each was a piece of the wood beneath, approximately one-half inch in thickness. The mats were placed separately in Lindlene plastic film bags, most of them twothirds quart size. These bags were then closed with small rubber bands, to hold in the moisture, and placed in an iced picnic box.

Not all mats were sampled or collected when found. As it was suspected that the lifting of bark over a mat might hasten deterioration or drying of the fungus, some mats were tagged and, for various periods of time, left undisturbed. At 2-week inspection intervals the bark was removed from these mats, several mats at each inspection, and the condition of each compared with the condition of mats of the same age which had been sampled and left on the trees. The lifting of bark from mats, and replacing it, did not noticeably hasten deterioration of the mats.

\section{Wood and Bark on Forest Floor}

It has been shown (Curl et al. 1952, 1953) that the thick mycelial mats of Endoconidiophora fagacearum develop on wood and bark pieces cut from wilt-killed oaks in the mat-producing stage and discarded or placed on the forest floor. Therefore, this type of growth must be considered as one of the possible sources of inoculum from which the disease could be spread.

The mat-producing stage of a wiltkilled tree may be described as the period of decline of the tree during which the bark is moderately loose and the wood beneath is light reddish-brown in color and has a strong amyl acetate or ripe fruit odor characteristic for the fungus. Preliminary tests showed that the ability of the fungus to grow out of the wood and form macroscopic growth is closely related to the presence of the ripe fruit odor.

As wilt-killed trees in the study areas reached the mat-producing stage, pieces of bark and wood measuring approximately 4 by 8 inches (the wood about an inch thick) were cut from the trunks where the ripe fruit odor was present. The bark and the wood were separated. The pieces of bark were placed, inner surfaces down, and the pieces of wood were placed, outer surfaces down, on the forest floor in shaded places. New pieces were cut and laid down about every 2 weeks from November 1, 1952, to July 1, 1953, until the trees had deteriorated to such an extent that they ceased to have the odor that indicated presence of the fungus. Mats that developed on these pieces were sampled in the same manner as those on trees.

\section{Insect Collections}

Insects found on mycelial mats were collected at the same time that the mats were sampled. Adults and larvae were placed in small vials and temporarily stored in the metal iced picnic boxes. Mats that were examined and left on the trees afforded a month-to-month opportunity to study insect populations occurring on mats of all ages. The influence of certain spe- 
cies of insects in hastening the decline of mats in nature was followed closely.

\section{Weather Data}

An attempt was made to relate average monthly temperatures and precipitation with conidial sporulation, perithecium formation, viability of spores, and general mat deterioration. Weather data were obtained from records of the United ner. A water suspension of conidia was prepared from a 7-day-old culture of $E n$ doconidiophora fagacearum and adjusted to approximately 300,000 spores per $\mathrm{ml}$. Circles were made with a wax pencil on the outside bottoms of Petri dishes containing 2 per cent water agar. One drop of suspension was placed on the surface of the agar within each circle, and each of the dishes was subjected to one of the

Table 2.-Germination of conidia of Endoconidiophora fagacearnm at various centigrade temperatures on 2 per cent water agar.

\begin{tabular}{|c|c|c|c|c|c|c|c|}
\hline \multirow{2}{*}{$\begin{array}{l}\text { Number } \\
\text { of Hours }\end{array}$} & \multicolumn{7}{|c|}{ Per Cent Germination at Designated Temperature } \\
\hline & $7^{\circ}$ & $16^{\circ}$ & $25^{\circ}$ & $28^{\circ}$ & $31^{\circ}$ & $34^{\circ}$ & $36^{\circ}$ \\
\hline $\begin{array}{l}12 \ldots \ldots \ldots \\
24 \ldots \ldots \ldots \\
36 \ldots \ldots \ldots \\
48 \ldots \ldots \ldots \ldots \\
60 \ldots \ldots \ldots \ldots\end{array}$ & $\begin{array}{l}0 \\
0 \\
0 \\
0 \\
0\end{array}$ & $\begin{array}{r}0 \\
2 \\
6 \\
11 \\
12\end{array}$ & $\begin{array}{r}3 \\
19 \\
48 \\
65 \\
74\end{array}$ & $\begin{array}{l}37 \\
83 \\
93 \\
94 \\
96\end{array}$ & $\begin{array}{r}9 \\
73 \\
86 \\
91 \\
92\end{array}$ & $\begin{array}{r}2 \\
16 \\
25 \\
29 \\
35\end{array}$ & $\begin{array}{l}0 \\
0 \\
0 \\
0 \\
0\end{array}$ \\
\hline
\end{tabular}

States Department of Commerce Weather Bureau for stations nearest the areas being studied. None of the study areas was more than 12 miles distant from the nearest weather station. It is realized that temperature and precipitation may vary to some extent within even this short distance, but it was not feasible to install expensive, unguarded weather-recording equipment in the wilt areas.

\section{LABORATORY STUDIES}

\section{Spore Germination}

The germination of conidia of Endoconidiophora fagacearum by other workers has already been reviewed. For these conidia, solid agar of a low dextrose content and malt solutions have been shown to be good germination media at 25 to 30 degrees $\mathrm{C} . *$ However, in the present studies, a medium and a temperature were desired that would insure a high percentage of germination, but that, at the same time, would tend to discourage growth of contaminating fungi and retard the production of secondary endoconidia.

The germinability of laboratory-grown conidia was tested in the following man-

* All temperatures given in this report, unless otherwise labeled, are degrees centigrade. following incubation temperatures: 7,16 , $25,28,31,34$, and 36 degrees at 12-hour intervals for 60 hours. Four hundred spores were counted for each test temperature, and a record was made of the number of spores germinated. Spores were considered germinated if the germ tubes were about the same length as the spores.

The highest germination rate was 96 per cent at 28 degrees; no germination occurred at 7 degrees nor at 36 degrees during the 60 -hour period, table 2. The upper limit of the germination range appeared to be 34 degrees, fig. 4 ; at that temperature, 35 per cent germination occurred, but the germ tubes did not continue to grow. Secondary sporulation appeared to be most abundant at 16 and at 25 degrees.

The germinability of conidia taken from naturally occurring mycelial mats was determined at 25 and at 28 degrees. Some of the spores were germinated on agar containing 2 per cent of dextrose and some on 2 per cent water agar. Most spore suspensions made from naturally occurring mats contained, in addition to conidia of Endoconidiophora fagacearum, spores and hyphal fragments of several other fungi, particularly species of Penicillium, Trichoderma, and Graphium. Drops of the suspension were placed on 


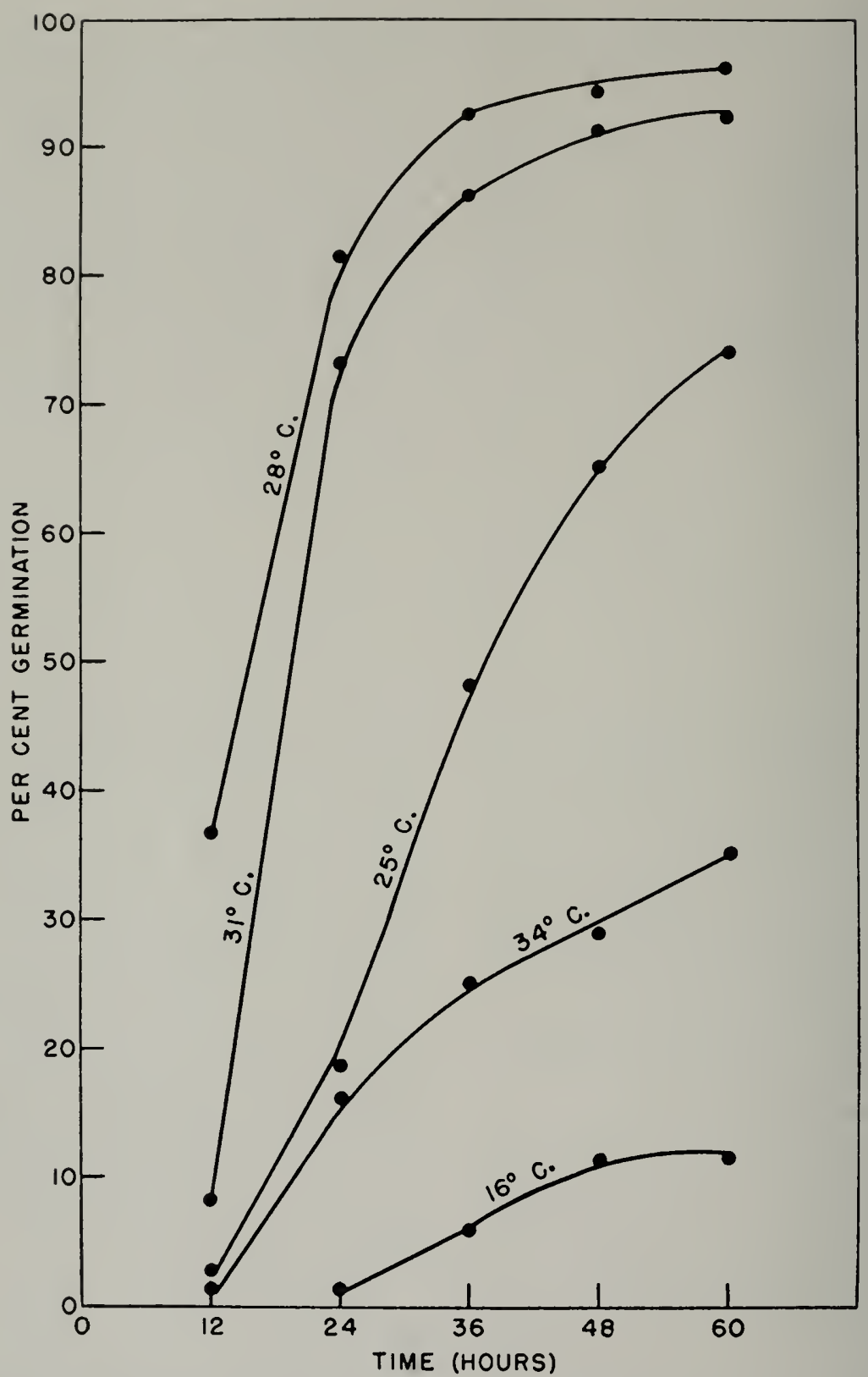

Fig. 4.-Germination of conidia of Endoconidiophora fagacearum on 2 per cent water agar at five temperatures.

the surfaces of the media as described for the 7-day-old culture above.

Germination of naturally occurring conidia was slightly higher on the dextrose agar at 28 degrees than on water agar at the same temperature. However, on dex- trose agar, the count was confused by the production of secondary conidia after 30 hours, and the contaminants made very rapid growth, further confusing the counting of germinated conidia.

Ascospores from laboratory cultures 
Table 3.-Germination of ascospores of Endoconidiophora fagacearum at various centigrade temperatures on 2 per cent water agar.

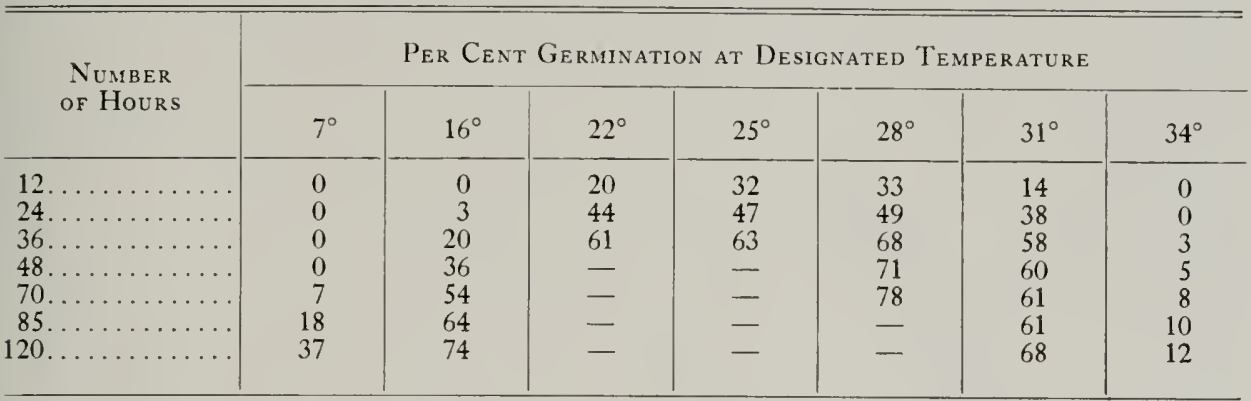

Table 4.-Germination of ascospores of Endoconidiophora fagacearum at various centigrade temperatures on 2 per cent dextrose agar.

\begin{tabular}{|c|c|c|c|c|c|c|c|}
\hline \multirow{2}{*}{$\begin{array}{l}\text { Number } \\
\text { of Hours }\end{array}$} & \multicolumn{7}{|c|}{ Per Cent Germination at Designated Temperature } \\
\hline & $7^{\circ}$ & $16^{\circ}$ & $22^{\circ}$ & $25^{\circ}$ & $28^{\circ}$ & $31^{\circ}$ & $34^{\circ}$ \\
\hline $\begin{array}{r}12 \ldots \ldots \ldots \\
24 \ldots \ldots \\
36 \ldots \ldots \\
48 \ldots \ldots \\
70 \ldots \ldots \\
85 \ldots \ldots \\
120 \ldots \ldots \\
\ldots \ldots \\
\ldots \ldots\end{array}$ & $\begin{array}{r}0 \\
0 \\
0 \\
0 \\
9 \\
12 \\
23\end{array}$ & $\begin{array}{r}0 \\
1 \\
14 \\
21 \\
53 \\
57 \\
70\end{array}$ & $\begin{array}{l}29 \\
58 \\
69 \\
- \\
- \\
-\end{array}$ & $\begin{array}{l}46 \\
75 \\
81 \\
- \\
- \\
-\end{array}$ & $\begin{array}{l}45 \\
69 \\
74 \\
79 \\
84 \\
- \\
-\end{array}$ & $\begin{array}{l}19 \\
49 \\
60 \\
73 \\
76 \\
78 \\
87\end{array}$ & $\begin{array}{l}0 \\
0 \\
2 \\
4 \\
5 \\
7 \\
8\end{array}$ \\
\hline
\end{tabular}

grown on chestnut agar ( $30 \mathrm{gm}$. chestnut meats and $20 \mathrm{gm}$. agar in 1 l. distilled water) were germinated in Petri dishes, some containing water agar and some 2 per cent dextrose agar; each dish was subjected to one of seven incubation temperatures: $7,16,22,25,28,31$, and 34 degrees. At most of the temperatures germination was slightly higher on dextrose agar than on water agar, tables 3 and 4 and figs. 5 and 6 , the highest germination for any single time interval occurring at 25 and 28 degrees. Secondary conidia started to form at about the same time for each temperature on both media. However, at an incubation temperature of 28 degrees, further production of conidia was retarded, so that at this temperature the counting of germinated ascospores was not confused by germinated conidia until after 70 hours. At incubation temperatures of 22 and 25 degrees, counts of ascospores became confused by germinated conidia after 36 hours. After 120 hours, ascospores incubated at 31 degrees had moderately long, unbranched germ tubes that did not sporu!ate, and spores incubated at $3+$ degrees had very short germ tubes that did not continue to grow.

After these tests, it was concluded that a 2 per cent water agar medium and an incubation temperature of 28 degrees for 36 hours would be best for determining germinability of both conidia and ascospores of Endoconiodiophora fagacearum.

\section{Sampling}

It is recognized that a larger number of samples than the three mycelial disks that were taken from each mat at each sampling might have been desirable in obtaining samples that were representative. However, as some mats were left on trees and sampled several times, the taking of a much larger number of samples would have destroyed the smaller mats.

A short test was run to find how great a difference might be expected between samples taken from different parts of a mat. Four immature (class I) mats were used in the test. Three disk samples (each $7 \mathrm{~mm}$. in diameter) were taken from each 


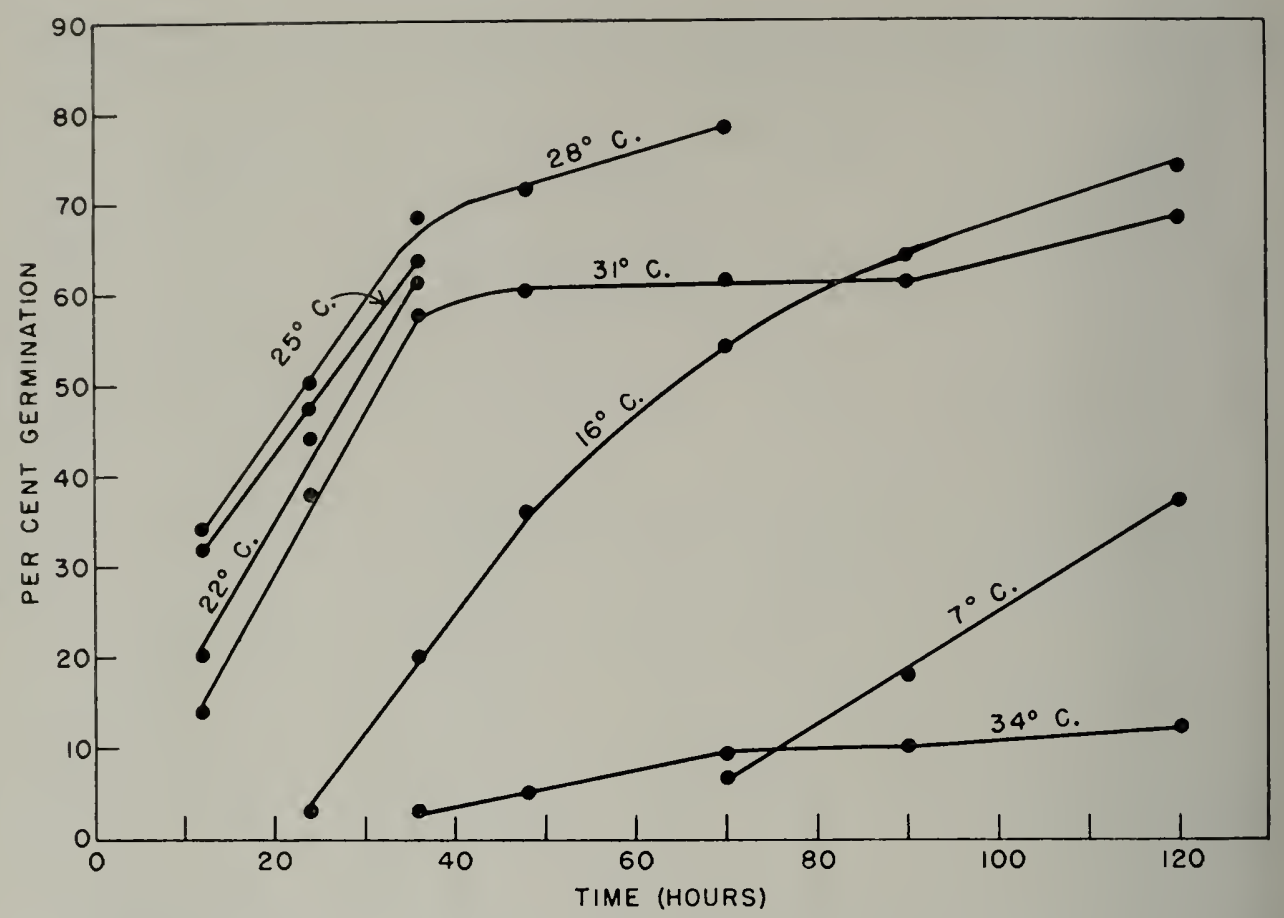

Fig. 5.-Germination of ascospores of Endoconidiophora fagacearum on 2 per cent water agar at seven temperatures.



Fig. 6.- Germination of ascospores of Endoconidiophora fagacearum on 2 per cent dextrose agar at seven temperatures. 
of three sides of each mat from the edge of the central pad to the periphery of mycelial growth. Each group of three disks was placed in a 10-nll. water blank and thoroughly crushed and shaken. The number of conidia in $1 \mathrm{ml}$. of suspension was then estimated, and the spores were germinated on water agar. The average number and per cent of germination of spores from each three-disk sampling were compared with the number and per cent of germination of conidia from other three-disk samplings on the same mat.

The approximate number of spores found on the four mats ranged on different mats from 280,000 to $1,300,000$ in
$1 \mathrm{ml}$. of suspension, and the germination rate ranged from 13 to 41 per cent. In no case was the difference in the average number of spores between any two samplings of the same mat greater than +0 ,000 , and the difference in germination rate did not exceed 5 per cent. It seems unlikely that such differences would be significant. Therefore, it is believed that representative samples were obtained by the method employed in these studies.

\section{Transporting Samples}

As it was necessary to store collected samples of the fungus at low tempera-
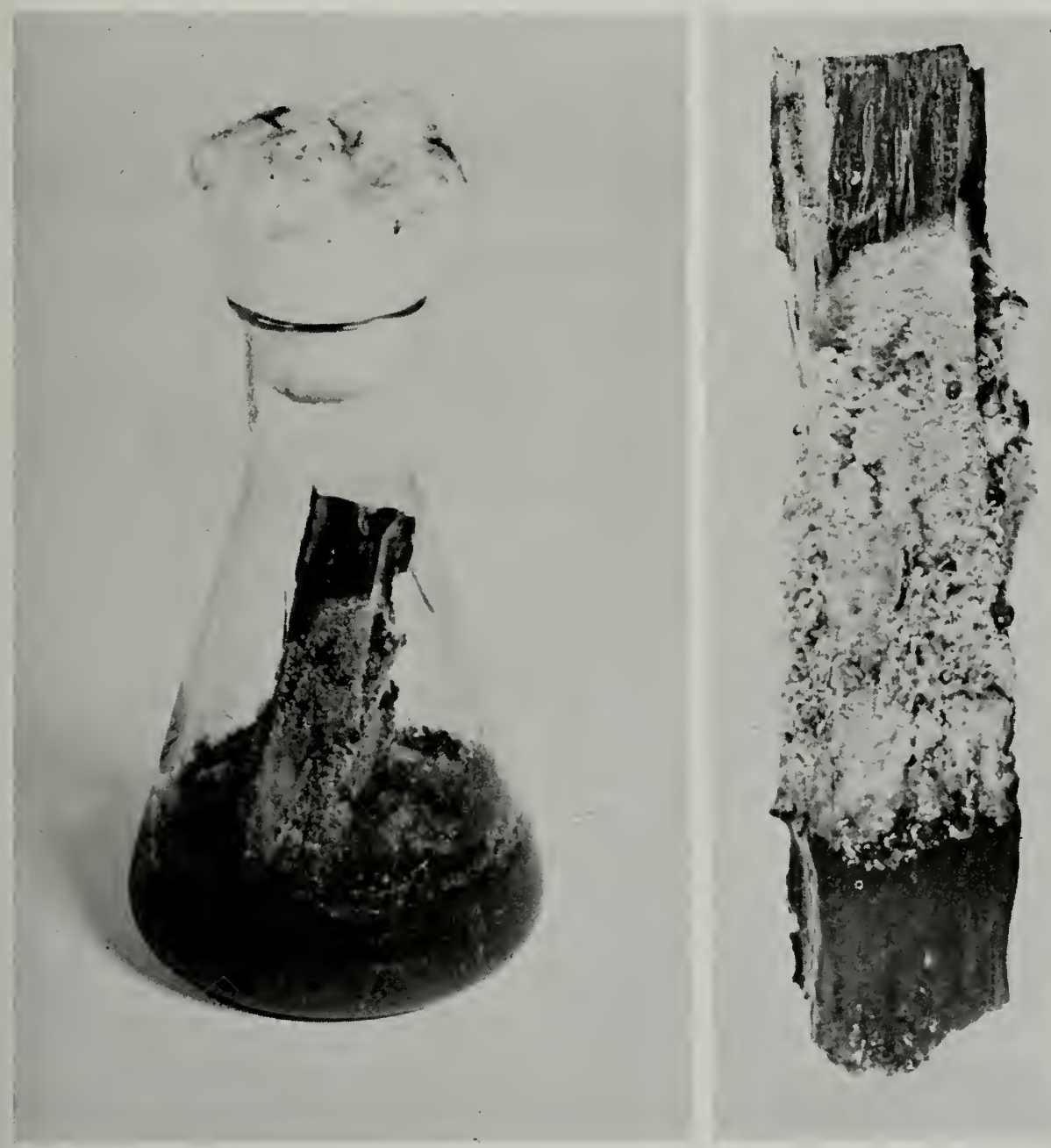

Fig. 7.-Mycelial mat of Endoconidiophora fagacearum grown on sterile oak wood in wheat bran broth. 
tures for several days in transferring them to the laboratory, the question arose concerning the possib!e effects of such temperatures on spore germination. Mycelial mats of Endoconidiophora fagacearum were grown in the laboratory in the following manner. Oak wood pieces meas- uring about 3 inches by 0.5 inch were placed on end in 250-ml. Erlenmeyer flasks which contained a wheat bran broth ( $8 \mathrm{gm}$. of wheat bran in $75 \mathrm{ml}$. of water). The bran broth was steam sterilized, and, when it was cool, a few drops of a spore suspension of the fungus were placed in
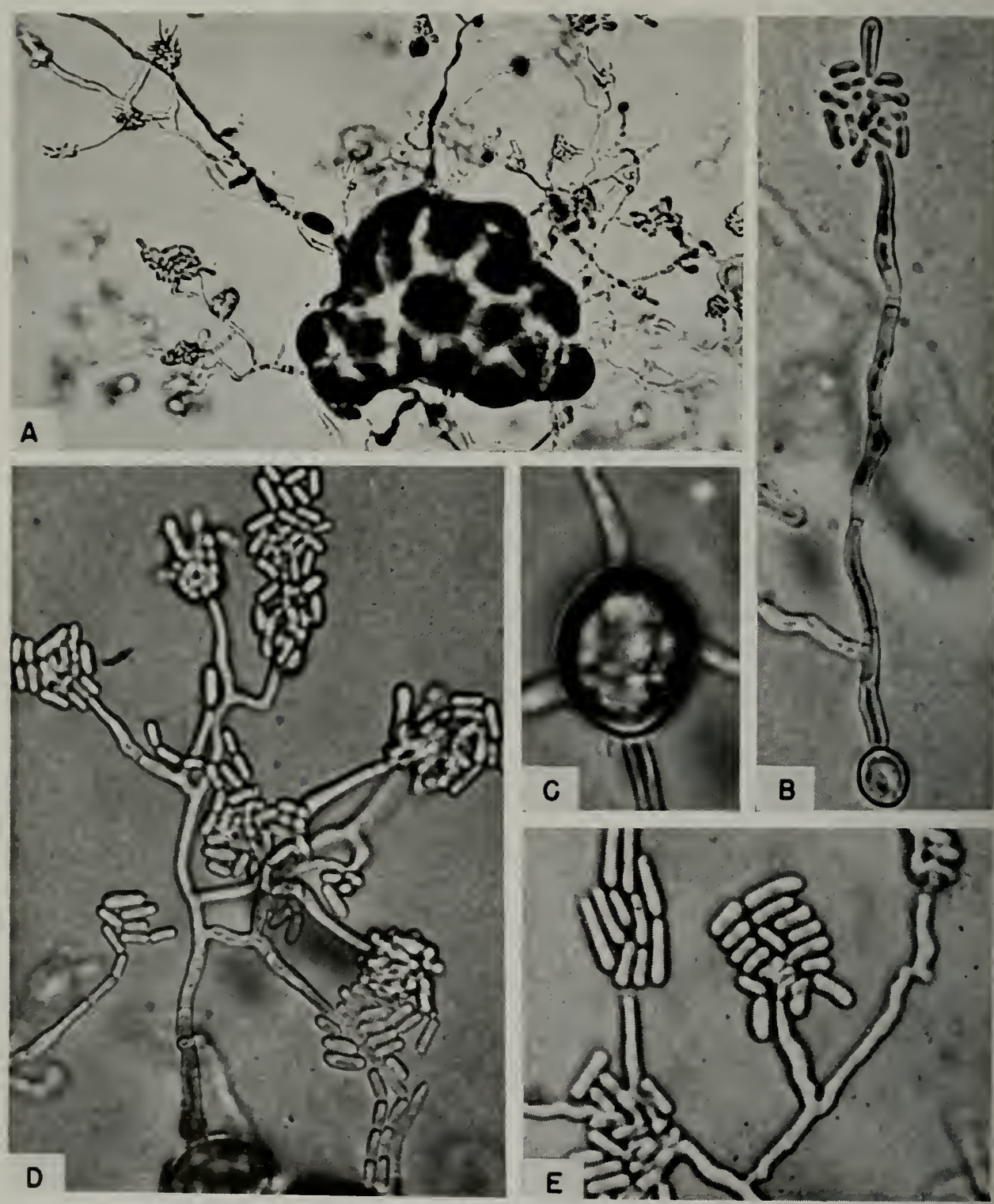

Fig. 8.-Germination of pad cells and conidia of Endoconidiophora fagacearum. A. Group of germinating pad cells producing abundant endoconidia, $\times 125$. B. Small germinating pad cell producing endoconidia after 12 hours at 22 degrees $C$., $\times 650$. $C$. Four germ tubes extending from a single pad cell, $\times 800$. $D$. Germinating pad cell with abundant sporulation after 48 hours at 28 degrees $C$., $\times 650$. $E$. Secondary sporulation by germinating conidia after 48 hours at 25 degrees C., $\times 800$. 
each flask. After 2 weeks at 25 degrees, one-half to three-fourths of each wood piece was found to be covered with a dense mat of mycelium free from the broth, fig. 7. In this laboratory test, methods of field sampling and storing were duplicated as nearly as possible. Disks of mycelium were taken from some pieces with a cork borer and transferred to moist filter paper in sterilized 4-ounce bottles. Whole pieces were placed in bags of plastic film and closed tightly with rubber bands. Some bottles and bags were then subjected to a temperature of 0 degree and some to a temperature of $16 \mathrm{de}-$ grees. For checks, germination counts were made of spores taken from some of the mats before treatment.

After 7 days, germination counts were made of spores in the test material. It was found that storage at 0 and at 16 degrees had no harmful effects on the spores. The germination rates were slightly higher for material stored at either of the two test temperatures than for the checks. Since the storage temperatures for field material were always within the range of 0 to 16 degrees for a period of time not exceeding 5 days, no serious fault could be seen in the storage methods used.

\section{Germination of Pad Cells}

Zuckerman \& Curl (1953) showed that single cells isolated from laboratorygrown mycelial pads of Endoconidiophora fagacearum are capable of producing typical cultures of the fungus on potato dextrose agar. Their finding suggested the possibility that pads on naturally occurring mats might constitute one of the sources of inoculum.

During the summer and autumn of 1953 , pad cells from mycelial mats that had been collected from wilt-killed oaks were used in making germination tests. The surface of each pad was cut away with a flamed scalpel, and a small portion of the interior was removed and crushed thoroughly in a sterile water blank to form a suspension of separated cells. Drops of the suspension were placed on the surface of 2 per cent water agar in plates and incubated at 25 degrees.

Good germination was always obtained with cells from the pads of immature (class I) mats in 30 hours. Commonly one or two germ tubes, and frequently four or five, were produced on a single cell, fig. $8 C$. The germ tubes branched prolifically, forming typical conidiophores which produced endoconidia abundantly, fig. $8 A, D$. Cells of all sizes, from 12 by 15 to 45 by 60 microns, germinated readily. The germination rate was in some cases as high as 87 per cent.

Germination of pad cells from mature (class II) mats was obtained only occasionally, and no germination of pad cells was obtained from mats in the more advanced stages of decline. The number of pad cells that appeared to be collapsed or plasmolyzed was greater in pads of advanced condition classes than in pads of classes I and II. Most deteriorating pads consisted of mycelial fragments, bacteria, and spores and hyphae of fungi other than Endoconidiophora fagacearum.

The temperature requirements for the germination of pad cells in vitro were determined and compared with similar requirements for germination of conidia and ascospores. A suspension of cells was prepared from the interior portion of a pad taken in September from an immature mat on a wilt-killed oak. Drops of the suspension were planted on the surface of 2 per cent water agar in Petri dishes and each dish subjected to one of five incubation temperatures: $8,15,22,28$, and 34 degrees. Counts of 200 cells for each temperature were made at intervals of 12 hours.

The highest germination rate of cells was 71 per cent at 22 degrees after 60 hours, table 5. Good germination occurred at 15 and 28 degrees, fig. 9. Among cells incubated at 8 degrees, germination did not begin for 36 hours. Among cells subjected to 34 degrees of temperature, germination did not take place during the 60 -hour period, nor later when the temperature was changed to 22 degrees. Production of conidia by the branches, or conidiophores, of the germ tubes occurred in 12 hours at 22 degrees, fig. $8 B$, and 28 degrees, and in 36 hours at 15 degrees. Sporulation seemed to be most abundant at 28 degrees, fig. $8 D$.

The results of the foregoing tests indicate that pad cells of Endoconidiophora fagacearum have a slightly lower opti- 
Table 5.-Germination of cells from pads of mycelial mats of Endoconidiophora fagacearum at various centigrade temperatures on 2 per cent water agar.

\begin{tabular}{|c|c|c|c|c|c|}
\hline \multirow{2}{*}{$\begin{array}{l}\text { Number } \\
\text { of Hours }\end{array}$} & \multicolumn{5}{|c|}{ Per Cent Germination at Designated Temperature } \\
\hline & $8^{\circ}$ & $15^{\circ}$ & $22^{\circ}$ & $28^{\circ}$ & $34^{\circ}$ \\
\hline $\begin{array}{l}12 . . \\
24 . . \\
36 . . \\
48 . \\
60 . .\end{array}$ & $\begin{array}{r}0 \\
0 \\
7 \\
17 \\
31\end{array}$ & $\begin{array}{r}6 \\
28 \\
57 \\
60 \\
60\end{array}$ & $\begin{array}{l}28 \\
63 \\
65 \\
70 \\
71\end{array}$ & $\begin{array}{l}30 \\
36 \\
41 \\
43 \\
50\end{array}$ & $\begin{array}{l}0 \\
0 \\
0 \\
0 \\
0\end{array}$ \\
\hline
\end{tabular}

mum temperature for germination than have conidia and ascospores. Also, the ability of germinated pad cells to sporulate abundantly on water agar seems to equal that of germinated conidia, fig. $8 E$, or ascospores.

\section{Production of Perithecia}

In conjunction with the study of perithecium formation under natural environmental conditions, a short experiment was conducted in vitro to determine what temperatures most favored the formation of perithecia. A wheat bran agar medium, consisting of $30 \mathrm{gm}$. of wheat bran and $20 \mathrm{gm}$. of agar in $1 \mathrm{l}$. of water, was used. Drops of a spore suspension from each of two compatible strains of Endoconidiophora fagacearum were placed approximately one-half inch apart on the surface of the medium near one edge of each plate. The plate was then slanted. forcing the drops to flow parallel with each other to the opposite side of the plate and, thus, distribute spores uniformly on the medium. All plates were incubated at 25 degrees for 7 days, and then placed in groups of six, each group for 16 more days at one of these temperatures: 7,12 , 16,25 , and 31 degrees. Perithecia were counted if the necks could be seen above the substrate with a binocular microscope.

An average of 51 perithecia per plate developed at 16 degrees, 47 at 25 degrees, and 11 at 12 degrees, table 6 . At the end of the 16-day incubation period, no perithecia had appeared in plates subjected to either 7 or 31 degrees. Similar results were obtained when the experiment was repeated.

\section{Longevity of Conidia}

The following experiment was conducted to determine the extremes of temperature and desiccation at which conidia of Endoconidiophora fagacearum may survive. Wooden tree labels, each 3.5 inches in length, were boiled in water for 1 hour. They were then placed on end in $250-\mathrm{ml}$. Erlenmeyer flasks, each containing $75 \mathrm{ml}$. of a wheat bran broth, and steam sterilized. The broth was seeded with drops of a conidial suspension and the flasks were incubated at 25 degrees for 2 weeks.

Table 6.-Production of perithecia by Endoconidiophora fagacearum at various centigrade temperatures on wheat bran agar.

\begin{tabular}{|c|c|c|c|c|c|}
\hline \multirow{2}{*}{ Replicate No. } & \multicolumn{5}{|c|}{ Number of Perithecia at Designated Temperature } \\
\hline & $7^{\circ}$ & $12^{\circ}$ & $16^{\circ}$ & $25^{\circ}$ & $31^{\circ}$ \\
\hline $\begin{array}{l}1 \ldots \\
2 \ldots \\
3 \ldots \\
4 \ldots \\
5 \ldots \\
6 \ldots\end{array}$ & $\begin{array}{l}0 \\
0 \\
0 \\
0 \\
0 \\
0\end{array}$ & $\begin{array}{r}8 \\
9 \\
5 \\
22 \\
7 \\
14\end{array}$ & $\begin{array}{l}38 \\
60 \\
32 \\
73 \\
37 \\
67\end{array}$ & $\begin{array}{c}91 \\
16 \\
51 \\
* \\
66 \\
10\end{array}$ & $\begin{array}{l}0 \\
0 \\
0 \\
0 \\
0 \\
0\end{array}$ \\
\hline Average. . & 0 & 11 & 51 & 47 & 0 \\
\hline
\end{tabular}

- No count possible; agar overrun by Graphium sp. 
At the end of this time the labels were fungus from one label of each flask, and found to be half covered with a uniform the spores were allowed to germinate on 2 mycelial growth. To serve as a check, a per cent water agar at 28 degrees for 36 spore suspension was prepared with the hours. Eighty-three per cent germination

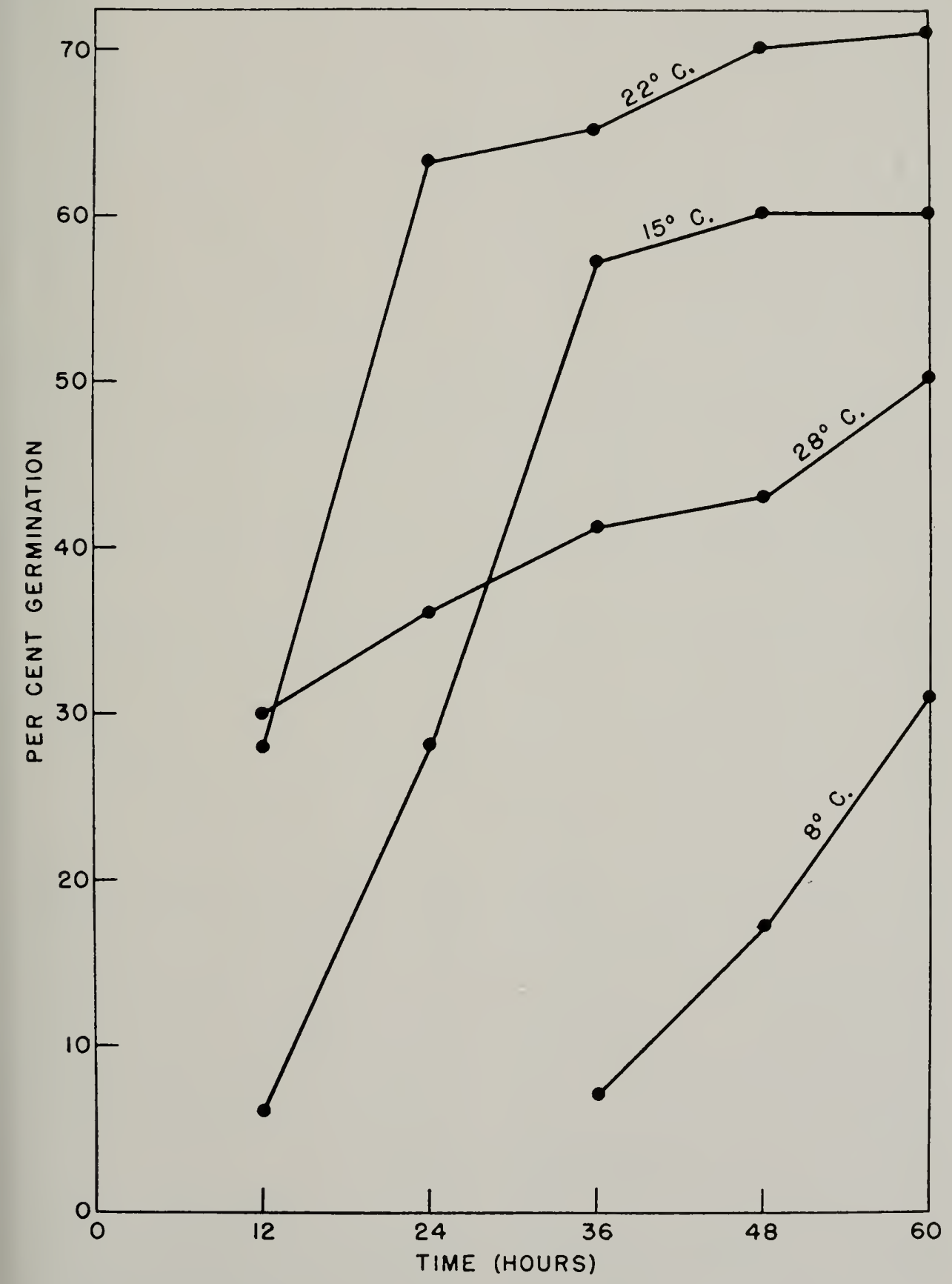

Fig. 9.-Germination of pad cells from naturally occurring mats of Endoconidiophora fagacearum on 2 per cent water agar at four temperatures. 
Table 7.-Longevity of conidia of Endoconidiophora fagacearum grown on sterile wood labels and stored in 100 per cent humidity at various centigrade temperatures.

\begin{tabular}{|c|c|c|c|c|c|c|}
\hline \multirow{2}{*}{$\begin{array}{l}\text { Number } \\
\text { of Dals }\end{array}$} & \multicolumn{6}{|c|}{ Per Cent Germination at Designated Temperature } \\
\hline & $0^{\circ}$ & $12^{\circ}$ & $16^{\circ}$ & $25^{\circ}$ & $31^{\circ}$ & $34^{\circ}$ \\
\hline $\begin{array}{r}0 \ldots \ldots \\
5 \ldots \ldots \\
10 \ldots \ldots \\
15 \ldots \ldots \\
25 \ldots \ldots \\
30 \ldots \ldots \\
35 \ldots \ldots \\
45 \ldots \\
55 \ldots \ldots \\
70 \ldots \\
85 \ldots \ldots \\
102 \ldots \ldots \\
162 \ldots \ldots \\
250 \ldots\end{array}$ & $\begin{array}{l}83 \\
80 \\
71 \\
70 \\
70 \\
55 \\
54 \\
49 \\
49 \\
45 \\
21 \\
10 \\
0 \\
0\end{array}$ & $\begin{array}{r}83 \\
70 \\
67 \\
66 \\
60 \\
33 \\
31 \\
17 \\
8 \\
7 \\
4 \\
2 \\
0 \\
0\end{array}$ & $\begin{array}{r}83 \\
75 \\
67 \\
57 \\
32 \\
7 \\
4 \\
1 \\
1 \\
0 \\
0 \\
0\end{array}$ & $\begin{array}{r}83 \\
39 \\
31 \\
26 \\
18 \\
0 \\
0 \\
0\end{array}$ & $\begin{array}{r}83 \\
40 \\
26 \\
3 \\
0 \\
0 \\
0\end{array}$ & $\begin{array}{r}83 \\
30 \\
6 \\
1 \\
0 \\
0 \\
0\end{array}$ \\
\hline
\end{tabular}

Table 8.- Longevity of conidia of Endoconidiophora fagacearum grown on sterile wood labels and stored in a dry atmosphere at various centigrade temperatures.

\begin{tabular}{|c|c|c|c|c|c|c|}
\hline \multirow{2}{*}{$\begin{array}{l}\text { Nimber } \\
\text { of Days }\end{array}$} & \multicolumn{6}{|c|}{ Per Cent Germination at Designated Temperature } \\
\hline & $0^{\circ}$ & $12^{\circ}$ & $16^{\circ}$ & $25^{\circ}$ & $31^{\circ}$ & $34^{\circ}$ \\
\hline $\begin{array}{r}0 \ldots \ldots \\
10 \ldots \ldots \\
20 \ldots \ldots \\
30 \ldots \\
35 \ldots \\
40 \ldots \\
50 \ldots \\
70 \ldots \\
85 \ldots \\
102 \ldots \\
162 \ldots \\
250 \ldots \\
\end{array}$ & $\begin{array}{l}83 \\
58 \\
48 \\
45 \\
41 \\
41 \\
40 \\
38 \\
33 \\
30 \\
31 \\
22\end{array}$ & $\begin{array}{l}83 \\
81 \\
76 \\
22 \\
20 \\
21 \\
14 \\
14 \\
13 \\
12 \\
10 \\
7\end{array}$ & $\begin{array}{r}83 \\
74 \\
74 \\
29 \\
25 \\
22 \\
20 \\
17 \\
14 \\
12 \\
8 \\
3\end{array}$ & $\begin{array}{r}83 \\
54 \\
10 \\
3 \\
3 \\
2 \\
1 \\
0 \\
0 \\
0\end{array}$ & $\begin{array}{r}83 \\
7 \\
2 \\
1 \\
0 \\
0 \\
0\end{array}$ & $\begin{array}{r}83 \\
2 \\
1 \\
0 \\
0 \\
0\end{array}$ \\
\hline
\end{tabular}

was recorded in a count of 300 spores. The remaining labels were transferred from the broth to sterile, dry beakers placed within 12 clean desiccators, 6 of which contained $200 \mathrm{ml}$. of sterile distilled water and the others $200 \mathrm{gr}$. of calcium chloride crystals. These desiccators were arranged in pairs (each pair having one desiccator with water and one with calcium chloride), and each pair was subjected to one of the following temperatures: $0,12,16,25,31$, and 34 degrees. Thus, the fungus was subjected to the extreme conditions of 100 per cent humidity and complete, or nearly complete, desiccation at temperatures ranging from freezing to high. At intervals, one label was taken from each desiccator, and a spore suspension was prepared from the fungus on the label. Each suspension was adjusted to 300,000 spores per ml., and drops of it were placed on the surface of water agar within circles marked on the outside of Petri dishes. These dishes were incubated at 28 degrees for 36 hours; then 300 spores were counted for each temperature and moisture condition tested and the per cent of germinated spores was determined.

Viable spores were taken from labels stored at 100 per cent humidity and 0 and 12 degrees temperature for 102 days, but no viable spores were found on labels stored at these temperatures for 162 days, 
table 7. Spores in the dry atmosphere at all temperatures, figs. 10 and 11. were still viable after 250 days at 0,12 , When the longevity and germinability of and 16 degrees, table 8 . The germinability of conidia from both the humid and the dry atmospheres decreased with time spores stored in a dry atmosphere were plotted (number of days on a logarithmic scale), the decrease in germinability of

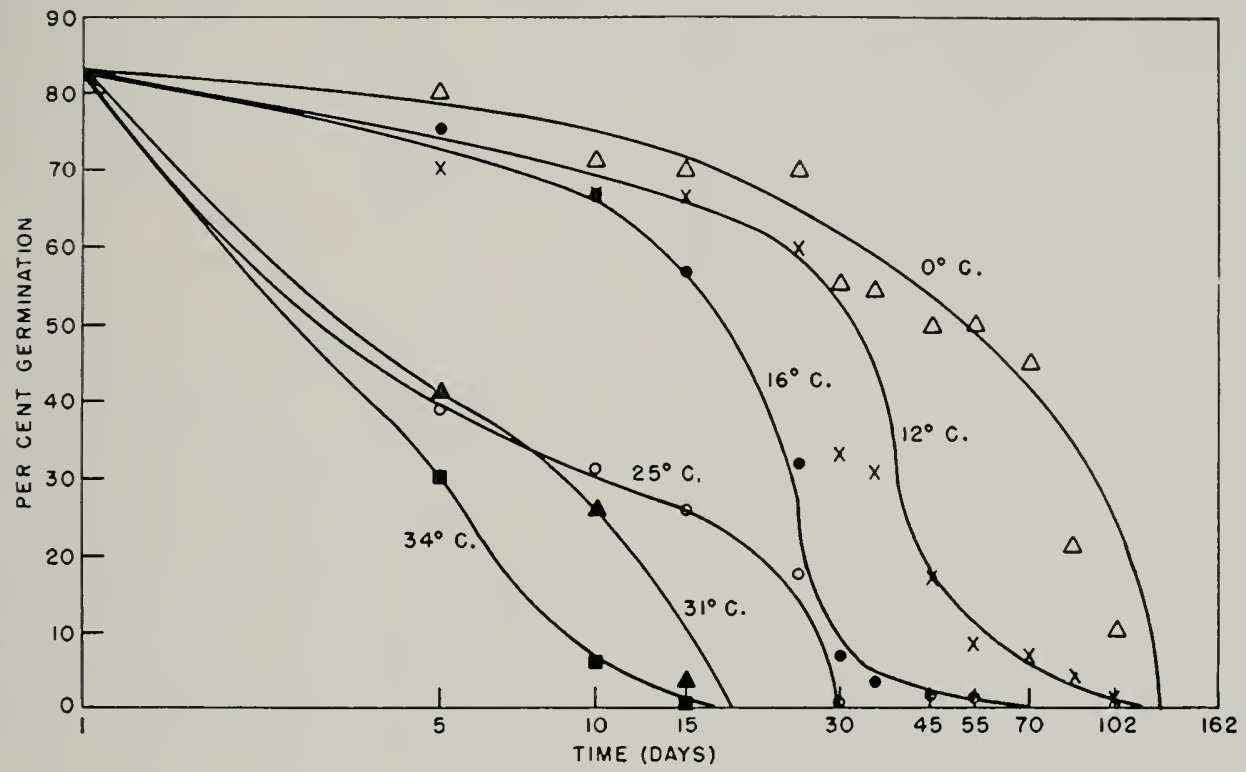

Fig. 10.-Germination of conidia of Endoconidiophora fagacearum stored at six temperatures in a water-saturated atmosphere. The curves illustrate the effect of temperature and humidity on longevity of the conidia.

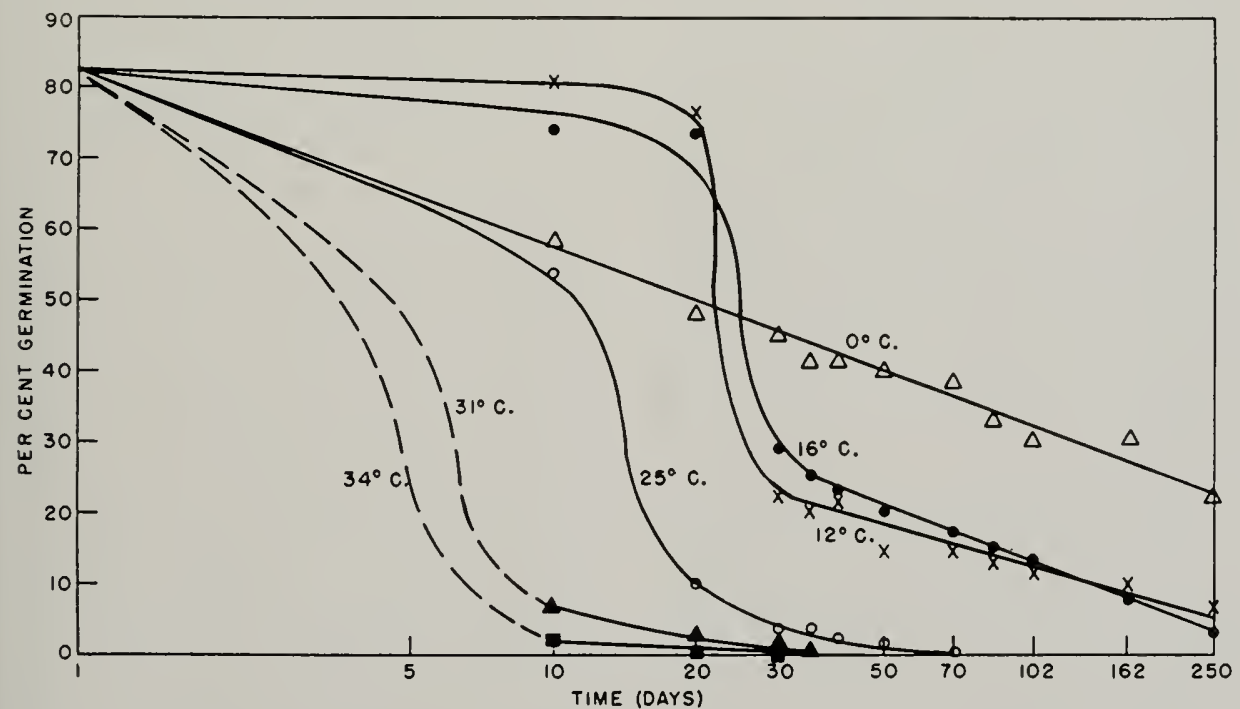

Fig. 11.-Germination of conidia of Endoconidiophora fagacearum stored at six temperatures in a dry atmosphere. The curves illustrate the effect of temperature and lack of humidity on longevity of the conidia. 
spores stored at 0 degrees was represented by a line that was nearly straight, while decreases in germinability of spores stored at other temperatures were represented by lines that showed abrupt decreases between time intervals.

Ten to 20 days after the last spore germination was observed, cultures of Endocoridiophora fagacearum were obtained, from mass transfers to potato dextrose agar, of fungus from the labels that were stored at 25,31 , and 34 degrees under both dry and humid conditions. Possibly these cultures resulted from a few still viable spores that could have been missed in the last germination test, or from some other part of the fungus that might have remained alive.

\section{Treatment of Samples From Nature}

Conidia.-Each set of three mycelial disk samples that had been taken from mats in the field was placed in a $10-\mathrm{ml}$. sterile water blank and thoroughly crushed and stirred with a glass rod to set the spores free in suspension. The approximate number of spores in $1 \mathrm{ml}$. of the suspension was determined with a Spencer Bright-Line counting chamber. This number divided by 3 gave the average number of spores in $1 \mathrm{ml}$. of water provided by a single disk sample $7 \mathrm{~mm}$. in diameter. The suspension was then adjusted to about 300,000 spores per $\mathrm{ml}$., and single drops were placed on the surface of water agar. The plates were incubated at 28 degrees for 36 hours and the per cent of germination determined from a count of 300 spores. The mycelial disks sometimes provided fewer than 300,000 spores per $\mathrm{ml}$. of suspension, in which cases the suspensions were plated in their original concentrations, and as many spores as could be found up to 300 were counted.

Mats that were collected whole in the field were sampled in the laboratory with a cork borer, as described on page 284 . Approximate numbers of conidia and their germinability were determined as described in the paragraph above.

Perithecia and Ascospores.-Perithecia were counted with the aid of a glass slide, one end of which was marked with black ink into several areas, each measuring $6 \mathrm{~mm}$. square. The slide was placed on the surface of a mycelial disk or whole mat and viewed through a binocular microscope. In the case of disk samples, counts were made of all perithecial necks seen within two to four of the square areas marked on the slide. In the case of whole mats, similar counts were made on each of four slides of the central pad. The average number of perithecia in a $6 \mathrm{~mm}$. square area of surface was determined for each whole mat and for each inat represented by disks.

From each perithecium-bearing mat, exuding masses of ascospores were picked at random from about 15 perithecial necks with a dissecting needle and stirred thoroughly in the well of a hanging-drop slide which contained sterile distilled water. Drops of the suspension were planted on water agar and incubated for spore germination as described for conidia. Data obtained are presented in the section titled "Availability of Fertile Perithecia," beginning on page 315 .

Mycelial Pads.-Interior parts of all pads and portions of pads that were collected in the field were transferred to potato dextrose agar to determine the viability of their cells. The plates were incubated at 25 degrees for 7 days. The results are given in table 22.

Further Treatment of Mats.-After the germinability of conidia and ascospores was determined, approximately 100 mats, involving all classes of condition shown in fig. 3, were placed in plastic film bags containing moist cotton; about half of them were stored at 12 and the rest at 16 degrees to determine their ability to renew vegetative growth. Renewed growth occurred only occasionally around the margins of immature mats and on parts of the wood pieces that had no growth previous to being stored. Most of the mats were overrun rapidly by contaminating fungi and bacteria.

Twenty-eight immature (class I) and mature (class II) mats were stored in the laboratory to determine the longevity of conidia and pad cells when mats are protected from natural environmental conditions. Some of these mats were placed in plastic bags with wet cotton and others were wrapped in dry paper toweling. They were then stored, some at 8 de- 
Table 9.-Longevity of conidia on mycelial mats of Endoconidiophora fagacearum placed in dry storage at two centigrade temperatures.

\begin{tabular}{|c|c|c|c|}
\hline $\begin{array}{l}\text { Mat } \\
\text { No. }\end{array}$ & $\begin{array}{c}\text { Storage } \\
\text { Temper- } \\
\text { ature }\end{array}$ & $\begin{array}{l}\text { DAYS IN } \\
\text { STORAGE }\end{array}$ & $\begin{array}{c}\text { Per Cent } \\
\text { Germina- } \\
\text { Tion of } \\
\text { Conidia }\end{array}$ \\
\hline $\begin{array}{l}\text { E-10. } \\
\text { E-17 } \ldots \\
\text { S-1 } \ldots \\
\text { E-15 } \ldots \\
\text { S- } 2 \ldots \ldots \\
S-3 \ldots \ldots\end{array}$ & $\begin{array}{l}8 \\
16 \\
16 \\
16 \\
16 \\
16\end{array}$ & $\begin{array}{r}30 \\
30 \\
150 \\
175 \\
205 \\
330\end{array}$ & $\begin{array}{r}75 \\
60 \\
24 \\
34 \\
13 \\
3\end{array}$ \\
\hline
\end{tabular}

grees and some at 16 degrees temperature, and tested at irregular intervals for viability of conidia and pad cells.

No viable conidia were found after 30 days on mats that were stored in moist bags. Most of these mats were badly deteriorated and overrun by contaminants. One mat, which was stored under dry conditions at 16 degrees, continued to yield viable spores for 330 days, table 9 . This mat, from which 3 per cent germination of conidia was obtained after 330 days, was very dry and brittle, and no reading could be registered from the wood with a Delmhorst Model RC-1 moisture detector (accurate to 25 per cent).

Pad cells did not germinate at any time during the storage period. In most instances the cells were colorless and appeared to be collapsed, or they had broken up into fragments.

\section{Insect Feeding Tests}

Insects that were found most frequently associated with Endoconidiophora fagacearum in the field were collected, identified to species when possible, ${ }^{*}$ and tested in the laboratory for their ability to destroy the fungus by feeding. $\mathrm{My}$ celial mats of $E$. fagacearum were grown on sterilized sticks of oak wood in flasks of wheat bran broth in the manner described on page 290. The sticks of oak wood bearing the fungus were taken from the broth and placed on moist filter paper in Petri dishes. Some of the insects that had been collected were allowed to feed

* Identification of all insects was made or arranged for by Dr. Milton W. Sanderson, Associate Taxonomist, Jllinois Natural History Survey. on this fungus and some on pad material alone; some of the pad material was obtained from naturally occurring mats and some from laboratory-grown pads. Pads were grown abundantly in the laboratory simply by planting the oak wilt fungus on wet wheat bran in Petri dishes and incubating it for approximately 3 weeks at temperatures that ranged between 16 and 25 degrees. $\dagger$

The only insects found to feed readily and with destructive effect on the mycelium and pads were species belonging to the family Nitidulidae. The species were Carpophilus niger, C. sayi, Carpophilus sp. (larvae), Colopterus truncatus, $C$. semitectus, Glischrochilus obtusus, $G$. sanguinolentus, and an unidentified species of Glischrochilus (larvae). Fig. 12 shows the feeding of Carpophilus larvae on the mycelium and pad material of $E_{n-}$ doconidiophora. The ambrosia beetles, Xyloterinus politus, Monarthrum mali, and $M$. fasciatum, and members of the order Collembola, or springtails, were observed feeding on mycelial mats, but their effects on the fungus were not macroscopically evident.

\section{FIELD OBSERVATIONS}

\section{Development of Mats}

During the course of this study, the decline of trees in each wilt area was followed closely over the 10-month study period, October, 1952, through July, 1953. The rate of decline of a wilt-infected oak and the length of time required for the tree to reach a condition favorable for the development of mycelial mats was found to be influenced by the place and time the wilt started. Wilt-infected trees in the more northern study areas, Chicago, Rockford, and Sinnissippi Forest, usually were producing mats 1 to 3 months earlier than trees that wilted at approximately the same time in the $\mathrm{Pe}$ oria and Havana areas, 125 to 150 miles southward. In the two southerly areas, the average monthly temperature for the 10 -month period was slightly higher and

† A method used for growing mycelial pads of Endoconidiophora fagacearum on artificial media was developed by E. B. Himelick, Assistant Plant Pathologist, Illinois Natural History Survey. 






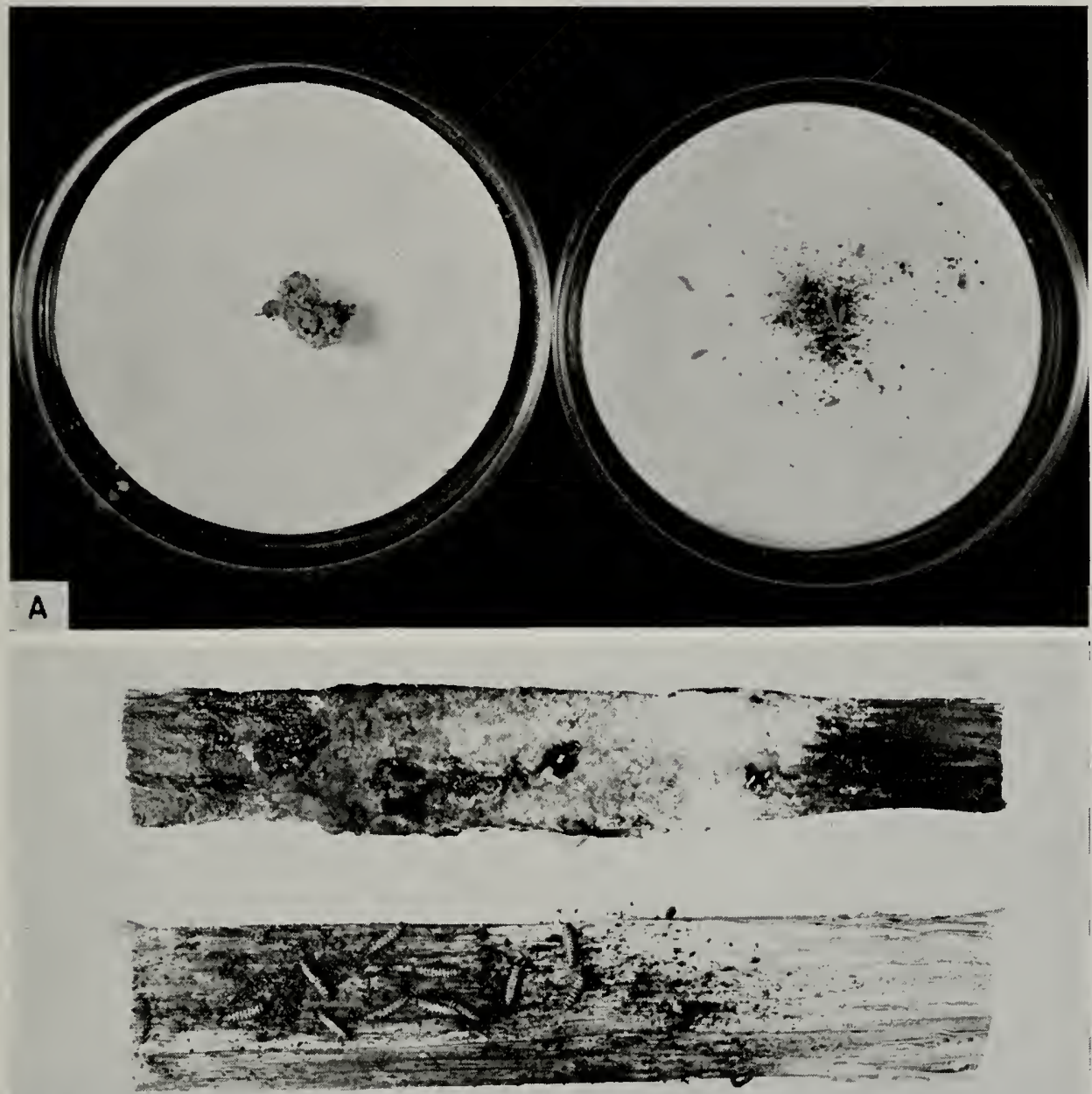

B

Fig. 12.-Carpophilus larvae feeding on Endoconidiophora fagacearum. A. Portions of laboratory-grown mycelial pad; left, without insects and, right, after exposure for 24 hours to larvae. $B$. Artificially grown mycelial mats; above, without insects and, below, after exposure for 24 hours to larvae.

the average monthly precipitation slightly lower than in the three northern areas. In most cases, trees that wilted in June, 1952 , produced their first mats in 4 to 11 months, those that wilted in July produced their first mats in 5 to 10 months, and those that wilted in August produced their first mats in 8 to 11 months and continued to produce new mats for periods of 1 to 4 months, table 10 . Most trees that wilted in June and July started producing mats in the fall or winter following and they continued to form new mats for 1 to 7 and 2 to 6 months, respectively, before the wood became too old or dry to support growth of the fungus.

Wilt-killed trees were found to undergo a gradual decline between the time of incipient wilt and the development of the first mats. The first evidence that a tree would soon be in the right condition for mat formation was the appearance of long, dark brown streaks in the sapwood, usually in a narrow strip along one side of the trunk. In some trees this strip started near the base of the trunk and be- 
came progressively narrower higher up, in others it appeared first at the top of the bole and progressed downward, and in still others it started at top and base at the same time. In some trees, the browning of the wood occurred in a spiral manner on the bole; with time the brown strip became gradual!y wider and was followed by loosening of the bark. Two to 5 weeks later the strong characteristic odor of the fungus could be detected. Usually at this stage, mycelial mats formed in a few days if weather conditions were favorable. Several days prior to mat formation, a uniform, very sparse, barely visible mycelial growth was seen on the surface of some of the odoriferous wood. When pieces of this wood were removed and kept moist at 12 degrees, pure cultures of $E_{n-}$ doconidiophora fagacearum appeared in 3 days. Frequently the first mats to form on a tree followed the decline of the tree so closely that the mats extended from the brown wood under loose bark to the adjacent green wood under tight bark.

In some trees, mats appeared first at the base of the trunk, but, in many trees, they appeared first at the top of the trunk or on some of the large branches. However, as the top part of the tree declined more rapidly than the lower part, and soon became dry, in most trees a larger number of mats formed on the lower half of the bole. The distances at which 355 mats were located above the ground on different trees in all areas were estimated. Of this number, 3 mats were found between 6 inches and 1 foot above the ground, 111 were located between 1 foot and 10 feet, 133 between 10 and 20 feet, $6+$ between 20 and 30 feet, 33 between 30 and 40 feet, and 11 at heights of 40 to 50 feet.

The areas of loose bark on a tree could be traced accurately by following the dull sound given off when the trunk was tapped lightly with a blunt instrument. Where mats were present the dull sound was pronounced, and close examination revealed small cracks in the crevices of the bark. However, not all cracks that appeared in the bark of wilt-killed oaks were the result of mycelial mat or pad growth. Occasionally very small cracks were found, beneath which the odor of the fungus was strong but where no mats or pads were visible. When the bark of these places was lifted, replaced immediately, and nailed down securely, abundant mycelial growth of Endoconidiophora fagacearum developed within 2 weeks. This experience indicated that cracks may precede mat formation. By the time the pressure created by mats growing beneath the bark is strong enough to crack the bark at crevices, the bark has been considerably weakened. During a period of rapid growth in the spring, many pads pushed the bark out so far that small pieces of the bark were dislodged, leaving portions of the pads exposed to the outside. The sizes of cracks in the bark seemed to vary according to the sizes of the mats beneath. In some instances, the combined effects of two mats, one below the other, caused very long cracks to form. The longest crack of this type found measured 3 feet.

The trunks of trees examined in the mat-producing stage did not always have the fungus odor distributed uniformly over the wood. In most trees in this stage, the odor occurred in small, scattered areas along the bole, the wood between these areas having none of the odor. When pieces of wood cut from areas with strong odor were placed in a moist chamber at 16 degrees, abundant mycelial growth of the oak wilt fungus appeared in 3 to 5 days. Wood that was taken from adjacent areas without odor did not produce any visible growth when treated in this manner.

Mats normally formed on the wood surface or on the surface of the inner bark of trees, but several mats were found which had developed entirely within the inner bark. These were typical mats with central pads, the largest measuring 18 by $6 \mathrm{~cm}$.

\section{Mats on Felled Trees}

Five wilt-killed trees selected for study of the development of mycelial mats on cut timber were felled at different times of the year. Tree H-4 (Havana area) was felled on September 23, 1952; tree P-6 (Peoria area) on October 21, 1952 ; tree R-8 (Rockford area) on November 3, 1952; tree R-7 on December 16, 1952 ; and tree R-6 on May 5, 1953. Trees H-4 and P-6 were felled in an early stage of 
decline, while the wood was still green and the bark very tight. The other trees had already started to produce mats before they were cut.

Tree $\mathrm{H}-4$ did not produce mats at any time. The bark loosened very slowly, and the fungus odor could never be detected in the wood. Tree P-6 did not produce mats until late in March, 1953, 5 months after it had been felled. Thirteen large mats were found on this tree up to May 5, after which no new mats were found. Twenty mats were found on tree R-8 at the time of cutting, and 14 additional mats appeared over a period of almost 5 months. The last mats to form on this tree were found on March 23, 1953. Tree R-7 had 10 mats when felled and produced only 1 more, which was found on April 21, 1953. Tree R-6 had 7 mats 2 weeks prior to being felled, 23 mats were present at the time of felling, and only 2 developed while the tree lay on the ground, these appearing in the early part of June, 1953.

After trees, whether felled or standing, ceased to produce new mats, the fungus sometimes could still be isolated from wood where the characteristic odor persisted. Where this odor could no longer be detected, the fungus could not be isolated.

\section{Stimulation in Mat Production}

Environmental Conditions.-From the time of the initial appearance of mats on a tree to the time when no further mat development occurred, the number of new mats varied from month to month. As each of the 30 trees used in these studies was examined every 2 weeks, all new mats that had formed since the previous examination were counted and tagged, fig. 13. It is believed that few, if any, mats with cracks* were missed; mats with cracks too small to be seen were located by the bark-tapping method.

The data in table 10 show the numbers of new mats found per month on individual trees, the total number of mats found on each tree during the 10 -month study period, and the total number found per

\footnotetext{
* Except where otherwise specified, all mats included in these studies were typical mycelial mats with central pads and associated with cracks in the bark of infected trees.
}

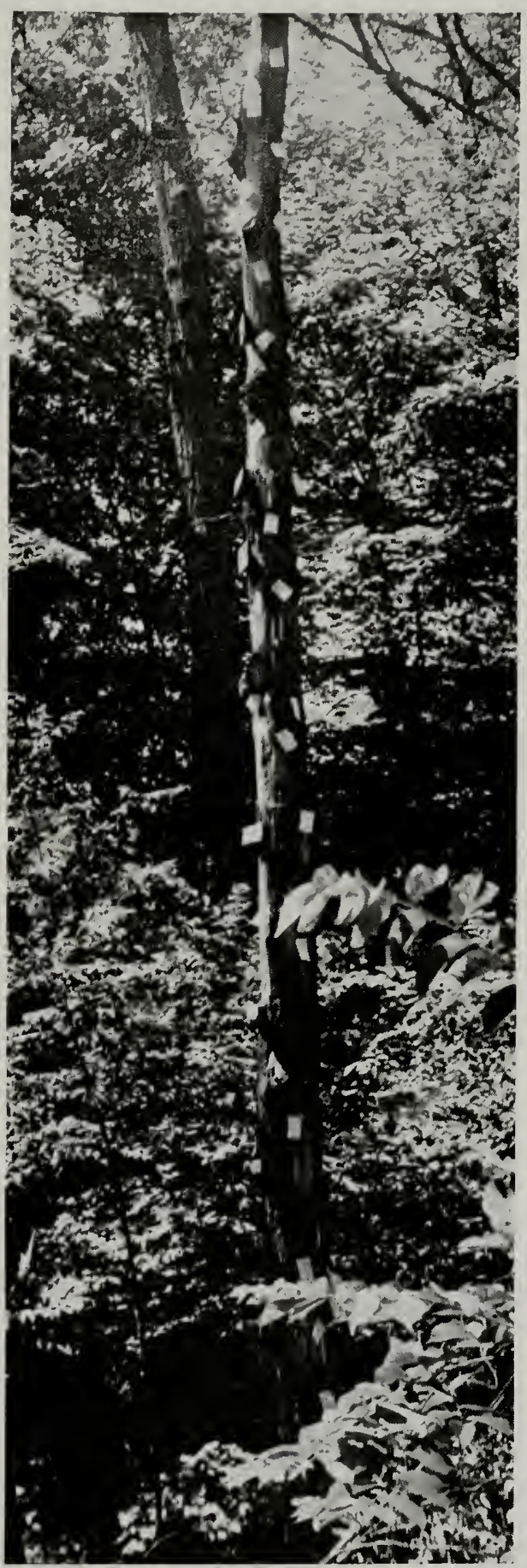

Fig. 13,-Wilt-killed oak tree, 10-inches d.b.h., marked with tags to show positions of mycelial mats. This tree was in a study area in northern Illinois. 


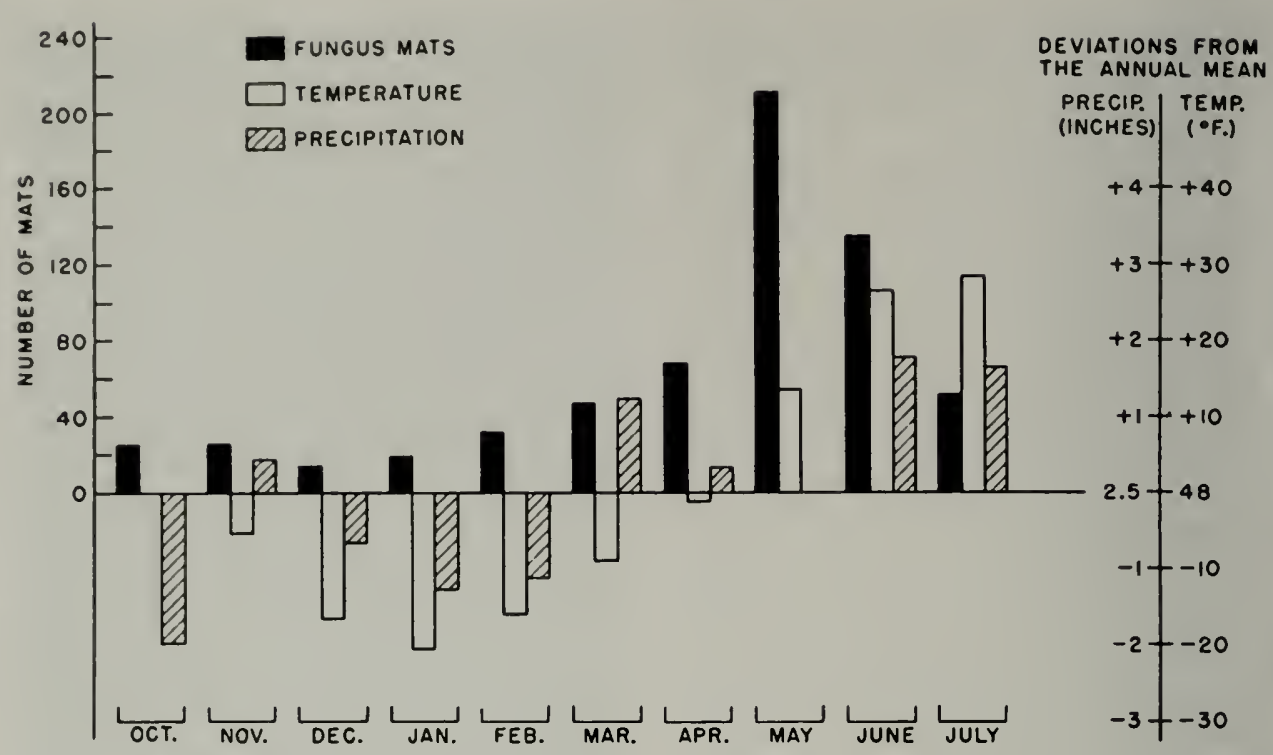

Fig. 14.- Monthly mean temperature and total precipitation, both shown as deviations from the annual means, and the numbers of mycelial mats of Endoconidiophora fagacearum found on wilt-killed oak trees in five Illinois study areas, October, 1952, through July, 1953. The bars illustrate the possible influence of monthly temperatures and precipitation on the numbers of mycelial mats of Endoconidiophora fagacearum produced on wilt-killed oaks. For lemperature in October and precipitation in May there were no deviations from the means.

month on all trees. It can be seen from these figures that mat development was greatly accelerated during April, May, and June. Some of the mats that were found in July were small and dry; many of them consisted only of pad material. They were found by removing bark from the trees. None of these undeveloped mats bore conidia of Endoconidiophora fagacearum.

Fig. 14 suggests the influences of monthly temperature and precipitation on mat formation. The average temperatures for May and June, respectively 16 and 22 degrees, approached the optimum temperature (about 25 degrees) for growth of the fungus. The maximum temperatures were 32 degrees in May and 40 degrees in June; each of these occurred on a day near the end of the respective month. Although the average temperature for July was only $2+$ degrees, a number of days during the month had maximum temperatures of 35 degrees. Thermometer readings showed that the temperature under the bark of wilt-killed oaks in unshaded areas was frequently as high as 40 degrees. During the winter months the highest average temperature for any month was 9 degrees, which is too low for rapid growth of the fungus. The total monthly precipitation for the five study areas during the winter months was generally below the annual mean, but during the spring and summer it was average or above.

The ripe fruit odor associated with $E_{n}$ doconidiophora fagacearum was most noticeable during May, probably because of the presence of a large number of mats on the trees. Only at this time of the year could the odor be detected clearly at a distance of 10 feet from the trunks of matbearing trees.

Wounds.-The development of macroscopic mycelial growth of the oak wilt fungus was sometimes stimulated by wounds made through the bark of trees that were in or nearing the mat-producing stage. This type of growth, noticeable only during March, April, and May in the study areas, was first seen late in March on tree R-7, which had been felled in December. Where small areas of bark had been cut from trees with an ax 2 weeks previously to check on the condition of the wood, dense masses of fresh mycelium had developed from the edges of the 
cuts to distances up to 2 feet back under the intact bark. Such patches of mycelium sometimes measured as much as 8 inches in width.

Wound-stimulated mycelial growth was most prevalent during April and May. On any tree that had the fungus odor beneath the bark, macroscopic growth could be induced to form merely by lifting a section of bark and immediately nailing it back in place. From the trunk of felled tree R-7, six pieces of bark, each measuring approximately 8 by 12 inches, were lifted. On two of the areas from which the bark had been lifted, the bare wood was covered with thin plastic, and the bark was replaced and nailed down securely. On two other areas, the inner bark surfaces were covered with plastic and nailed back over the wood. On two other areas the bark pieces were only lifted and immediately nailed back in place.

On the areas where the wood was covered with plastic, abundant growth of Endoconidiophora fagacearum appeared within 2 weeks on the under side of the bark only. Two weeks later this growth was old, but still no mycelium had formed on the plastic-covered wood beneath. On the areas which had the inner surface of the bark covered, growth appeared on both bark and wood, more abundantly on the covered surface of the bark than on the wood. On the areas where bark was simply lifted and replaced, good growth occurred on both bark and wood surfaces. Similar results were obtained on felled tree R-8 and on several standing trees.

Wounding not only stimulated free mycelial growth, but it also of ten hastened the development of typical mats with pads. For typical mats to appear adjacent to previously made cuts was common during April and May. In many cases the pads pushed the bark out at the edges of the cuts, exposing the mats to the outside. Also, mats appeared first on some trees at points where large nails had been driven through the bark in the process of building ladders on the trunks. These observations indicate that mat formation is stimulated by additional air from the outside.

\section{Mats on Bark on Forest Floor}

From November, 1952, through July, 1953, 213 bark pieces and 128 wood pieces were taken from wilt-killed oaks and placed on the forest floor in four

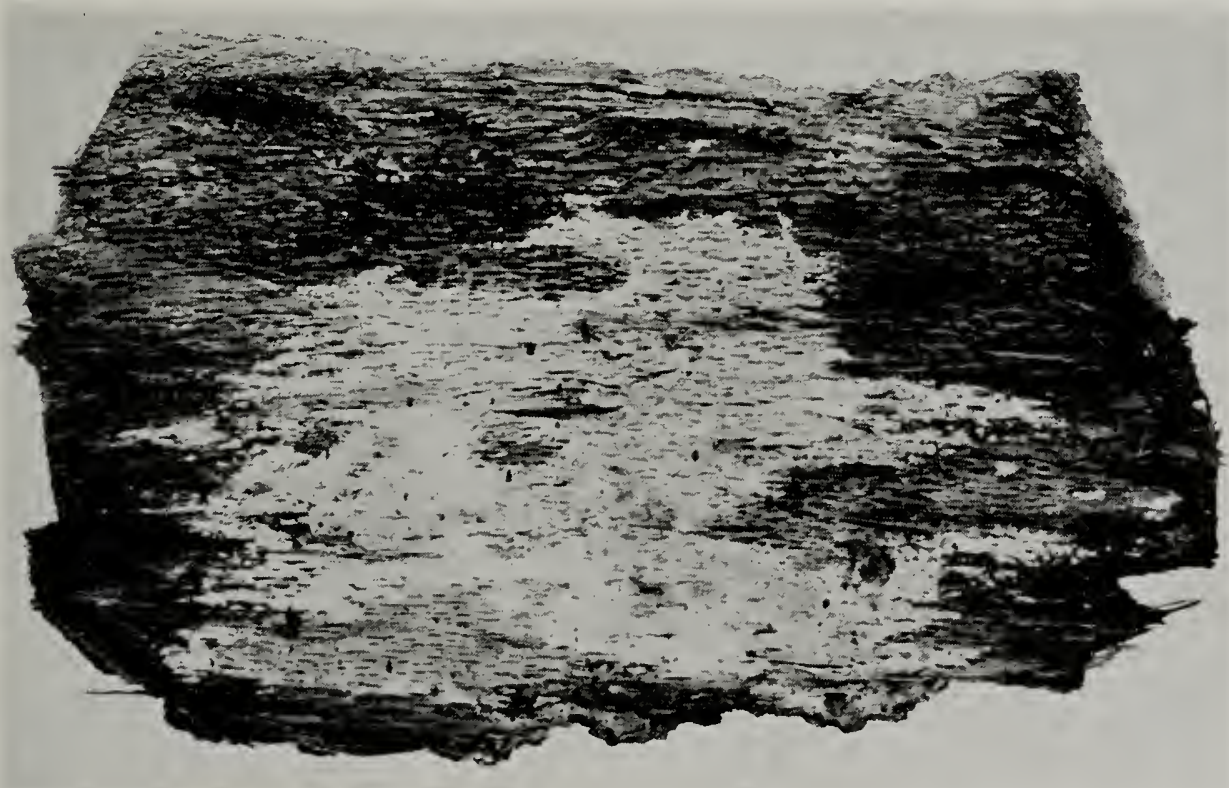

Fig. 15.-Mycelial mat of Endoconidiophora fagacearum formed on a piece of bark from a wilt-killed oak while the bark lay on the forest floor. 
study areas. Mycelial mats, fig. 15, appeared on only 17 of the bark pieces, table 11. The first such growth known to appear was found on March 24; the last in the early part of April. No visible mycelium of the oak wilt fungus tormed on the wood pieces at any time. This absence of growth on the wood is not explained, as it was shown earlier by Curl et al. (1953) in Illinois that mats of $E_{n}$ doconidiophora fagacearum developed on both bark and wood on the forest floor. All pieces of bark that produced a visible growth of fungus had been placed on the ground 2 weeks before the fungus appeared. Most pieces on which the fungus was not visible after 2 weeks were very dry or were overrun by other fungi. Wood and bark placed on the ground after April dried too rapidly to allow the fungus to develop, at least in visible amounts.

\section{Decline of Mats}

The rate of progress of mycelial mats from the immature stage to a deteriorated condition varied considerably according to the time of year when the mats appeared, table 12. Most immature mats found during November, December, and January required 70 to 84 days to reach a stage of deterioration. Mats that were found in the immature condition during February, March, and April became deteriorated in about 42 days, and mats that formed in May, June, and July declined very rapidly, sometimes requiring less than 14 days for complete deterioration.

Table 11.-The development of mycelial mats of Endoconidiophora fagacearum on bark and wood pieces that were taken from diseased oaks and placed on the forest. floor.

\begin{tabular}{|c|c|c|c|c|}
\hline \multirow{2}{*}{$\begin{array}{c}\text { MoNTh } \\
(1952-1953)\end{array}$} & \multicolumn{2}{|c|}{ BARK } & \multicolumn{2}{|c|}{ IVOOD } \\
\hline & $\begin{array}{c}\text { Number of } \\
\text { Pieces }\end{array}$ & $\begin{array}{c}\text { Number With } \\
\text { Mats }\end{array}$ & $\begin{array}{c}\text { Number of } \\
\text { Pieces }\end{array}$ & $\begin{array}{c}\text { Number With } \\
\text { Mats }\end{array}$ \\
\hline 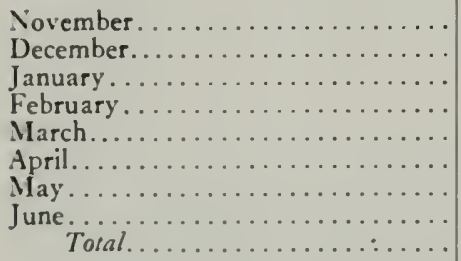 & $\begin{array}{r}22 \\
20 \\
22 \\
20 \\
40 \\
27 \\
21 \\
21 \\
213\end{array}$ & $\begin{array}{r}0 \\
0 \\
0 \\
0 \\
4 \\
13 \\
0 \\
0 \\
17\end{array}$ & $\begin{array}{r}20 \\
14 \\
14 \\
9 \\
22 \\
13 \\
14 \\
11 \\
128\end{array}$ & $\begin{array}{l}0 \\
0 \\
0 \\
0 \\
0 \\
0 \\
0 \\
0 \\
0\end{array}$ \\
\hline
\end{tabular}

Table 12.-The rates of development and decline of mycelial mats of Endoconidiophora fagacearum appearing on wilt-killed oaks; as indicated by the condition classes of the mats at 14. day intervals, the rate of development and decline of each mat was influenced by the month in which it first appeared.

\begin{tabular}{|c|c|c|c|c|c|c|c|}
\hline \multirow{2}{*}{$\begin{array}{l}\text { Month Mat } \\
\text { Appeared }\end{array}$} & \multicolumn{7}{|c|}{$\begin{array}{c}\text { Condition Class* of Mats on Designated Number of Days After First } \\
\text { Appearance }\end{array}$} \\
\hline & $\begin{array}{c}0 \\
\text { Days }\end{array}$ & $\begin{array}{l}14 \\
\text { Days }\end{array}$ & $\begin{array}{l}28 \\
\text { Days }\end{array}$ & $\begin{array}{l}42 \\
\text { Days }\end{array}$ & $\begin{array}{l}56 \\
\text { Days }\end{array}$ & $\begin{array}{l}70 \\
\text { Days }\end{array}$ & $\begin{array}{l}84 \\
\text { Days }\end{array}$ \\
\hline 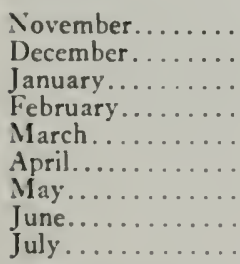 & $\begin{array}{l}\text { I } \\
1 \\
1 \\
1 \\
\text { I } \\
\text { I } \\
\text { I } \\
1 \\
1\end{array}$ & $\begin{array}{l}\text { II } \\
\text { II } \\
\text { II } \\
\text { III } \\
\text { II } \\
\text { II } \\
\text { II } \\
\text { V } \\
\text { V }\end{array}$ & $\begin{array}{l}\text { III } \\
\text { III } \\
\text { III } \\
\text { IV } \\
\text { III } \\
\text { IV } \\
\text { V }\end{array}$ & $\begin{array}{l}\text { IV } \\
\text { IV } \\
\text { IV } \\
\text { V } \\
\text { V } \\
\text { V }\end{array}$ & $\begin{array}{l}\text { IV } \\
\text { IV } \\
\text { IV }\end{array}$ & $\begin{array}{l}\text { IV } \\
\text { V } \\
\text { V }\end{array}$ & $\mathrm{V}$ \\
\hline
\end{tabular}

-Condition class I, immature; II, mature; III, aging; IV, declining: V, deteriorating. 


\section{Insects Associated With Mats}

The possibility that several insects which are often associated with the fruiting mats of Endoconidiophora fagacearum might spread oak wilt inoculum to wounds of healthy trees was pointed out by Nor- ris (1953) in Iowa and by Dorsey et al. (1953) in West Virginia. These workers obtained mechanical transmission of oak wilt under experimental conditions with several species of the Nitidulidae. Griswald \& Neiswander (1953) in Ohio suggested that the pomace fly, Drosophila

Table 14.-Numbers of mycelial mats of Endoconidiophora fagacearum in five condition classes* on which individual species of insects were found in the 10 -month period October, 1952, through July, 1953. Figures within parentheses indicate the numbers of mats examined.

\begin{tabular}{|c|c|c|c|c|c|c|c|}
\hline & Insect Group & & UMBE & $\begin{array}{l}\text { ER of } \\
\text { INS }\end{array}$ & $\begin{array}{l}\text { Mat } \\
\text { Ects }\end{array}$ & $\mathrm{rS} \mathrm{W}_{17}$ & \\
\hline Family & Genus and Species & 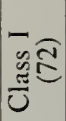 & $\begin{array}{l}= \\
\tilde{y} \\
\tilde{y}\end{array}$ & 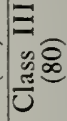 & 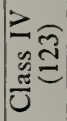 & $\begin{array}{l}>\mathbb{E} \\
\tilde{n} \tilde{N}= \\
\dot{0}\end{array}$ & 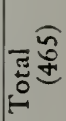 \\
\hline Anthocorida & Lyctocoris stalii. & 0 & 0 & 0 & 3 & 0 & 3 \\
\hline Blat & Parcoblatta sp... & 0 & 1 & 1 & 11 & 4 & 17 \\
\hline Bre & Eupsalis minuta. & 0 & 0 & 0 & 7 & 12 & 19 \\
\hline But & Agrilus bilinentus, larvae............. & 0 & 1 & 0 & 0 & 0 & 1 \\
\hline Cara & Pristodactyla impunctata................ & 0 & 0 & 3 & 3 & 5 & 11 \\
\hline Colydiidae & Aulonium parallelopipedum............. & 0 & 1 & 3 & 11 & 3 & 18 \\
\hline & Bothrideres geminatus................... & 0 & 0 & 0 & 1 & 2 & 3 \\
\hline & 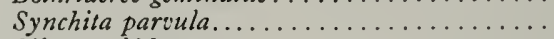 & 0 & 1 & 1 & 1 & 0 & 3 \\
\hline Cucujidae. & 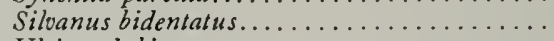 & 1 & 0 & 5 & 12 & 11 & 29 \\
\hline & 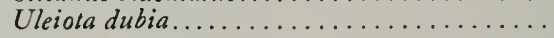 & 0 & 0 & 0 & 2 & 2 & 4 \\
\hline Collembola (order) & & 1 & 6 & 6 & 25 & 15 & 53 \\
\hline Curculioni & Pandeleteius hilaris. . & 0 & 0 & 0 & 2 & 0 & 2 \\
\hline Elateridae & Ampedus nigricans... & 0 & 0 & 0 & 1 & 0 & 1 \\
\hline & 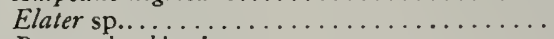 & 0 & 0 & 0 & 2 & 0 & \\
\hline Histeridae & 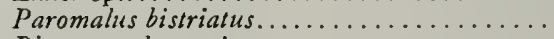 & 0 & 1 & 9 & 13 & 38 & 61 \\
\hline & 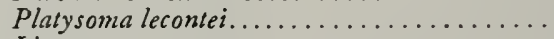 & 0 & 0 & 7 & 12 & 26 & 45 \\
\hline Mycetophagidae & 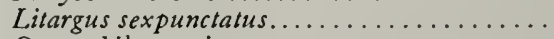 & 0 & 0 & 0 & 2 & 0 & 2 \\
\hline Nitidul & 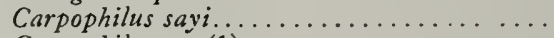 & 0 & 1 & 9 & 6 & 1 & 17 \\
\hline & Carpophilus sp. (1). & 0 & 0 & 0 & 1 & 0 & \\
\hline & 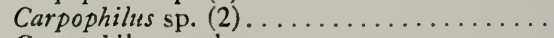 & 0 & 1 & 2 & 0 & 1 & \\
\hline & Carpophilus sp., larvae............... & 0 & 1 & 5 & 18 & 13 & 37 \\
\hline & 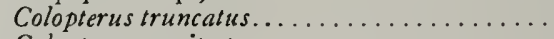 & 7 & 8 & 14 & 8 & 1 & 38 \\
\hline & Colopterus semitectus. . . . . . . . . . . . . & 0 & 5 & 14 & 13 & 2 & 34 \\
\hline & 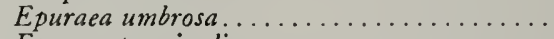 & 0 & 0 & 4 & 0 & 0 & \\
\hline & 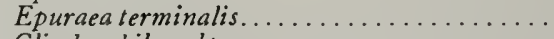 & 1 & 4 & 6 & 1 & 0 & 12 \\
\hline & Glischrochilus obtusus................. & 1 & 3 & 16 & 5 & 7 & 32 \\
\hline & Glischrochilus sanguinolentus............. & 0 & 0 & 3 & 1 & 0 & \\
\hline & Glischrochilus sp., larvae................. & 0 & 3 & 4 & 12 & 24 & 43 \\
\hline & er nitidulid larvae. . . . . . . . . . . . . & 0 & 1 & 8 & 18 & 15 & 42 \\
\hline Orthoperidae. & 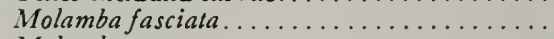 & 0 & 0 & 0 & 3 & 1 & \\
\hline & $\ldots \ldots \ldots \ldots \ldots \ldots$ & 0 & 0 & 0 & 2 & 0 & \\
\hline Ost & Tenebroides laticollis.. & 0 & 0 & 3 & 9 & 2 & 14 \\
\hline Rhi & Rhizophagus bipunctatus.. & 1 & 0 & 0 & 3 & 2 & \\
\hline Scolytidae & 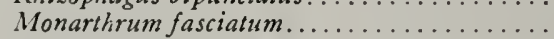 & 0 & 1 & 5 & 3 & 1 & 10 \\
\hline & 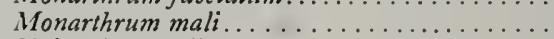 & 0 & 3 & 5 & 2 & 1 & 11 \\
\hline & Xyloterinus politus..................... & 1 & 0 & 13 & 9 & 0 & 23 \\
\hline Staphylinida & 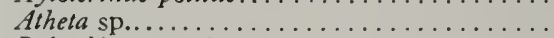 & 3 & 9 & 18 & 28 & 13 & 71 \\
\hline & Boletobius quaesitor...... & 0 & 0 & 5 & -5 & 2 & 12 \\
\hline & Coproporus ventriculus.................. & 0 & 0 & 0 & 3 & 2 & \\
\hline & 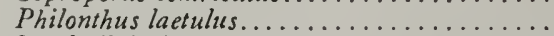 & 0 & 0 & 2 & 2 & 2 & 6 \\
\hline & 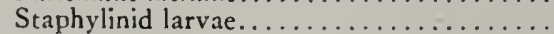 & 0 & 0 & 1 & 0 & 11 & 12 \\
\hline & Tachinus sp.. & 0 & 0 & 0 & 2 & 1 & \\
\hline Tenebrionidae. & Cynaeus angustus......... & 0 & 3 & 1 & 0 & 0 & \\
\hline & Platydema ruficorne........ & 0 & 0 & 2 & 1 & 0 & \\
\hline Trichoceridae & Trichocera sp., larvae........ & 0 & 0 & 2 & 2 & 7 & 11 \\
\hline
\end{tabular}

- Condition class I, immature; II, mature; III, aging; IV, declining; V, deteriorating. 
melanogaster, which, like the Nitidulidae, is attracted to mycelial mats of the oak wilt fungus and to bleeding wounds on healthy oak trees, might be a vector of oak wilt. In the study reported here, many other insects were found to be associated with naturally occurring fungus mats. From October, 1952, through July,
1953, at least to species of insects belonging to at least 33 genera of 19 families (exclusive of Collembola) were collected from mycelial mats on wilt-killed oak trees in Illinois, tables 13 and 14 .

Insects associated with mats are not only potential vectors of oak wilt, but they play other roles that affect the life
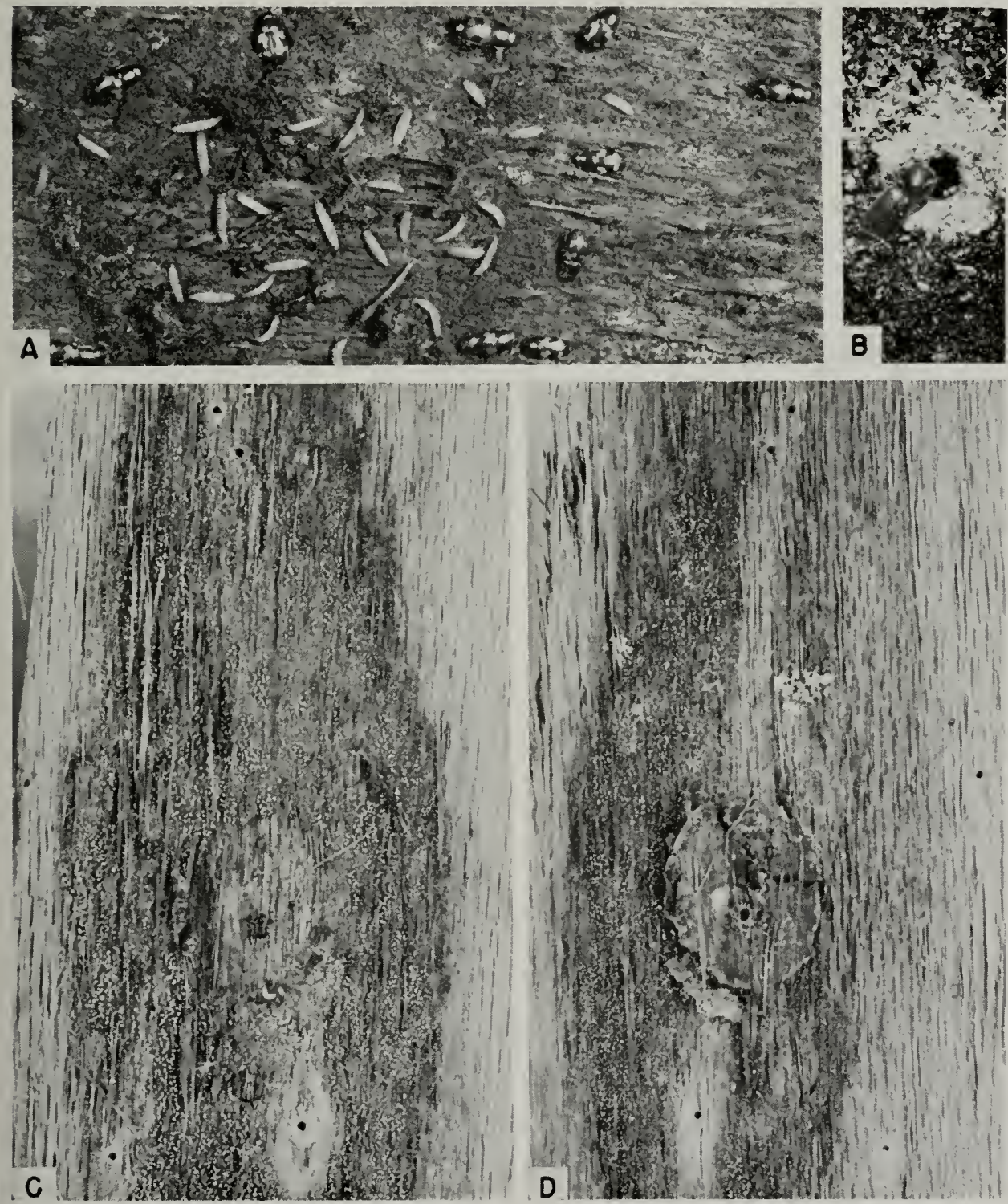

Fig. 16.-Insect activity on naturally occurring mycelial mats. A. Adults of Glischrochilus obtusus and larvae of Carpophilus sp. have completely destroyed this mat. B. Bark beetle (Scolytidae) and freshly made hole in fungus mat. $C$. and $D$. Holes made through peritheciumbearing mat and pad on wood and bark by adults of the Scolytidae. 


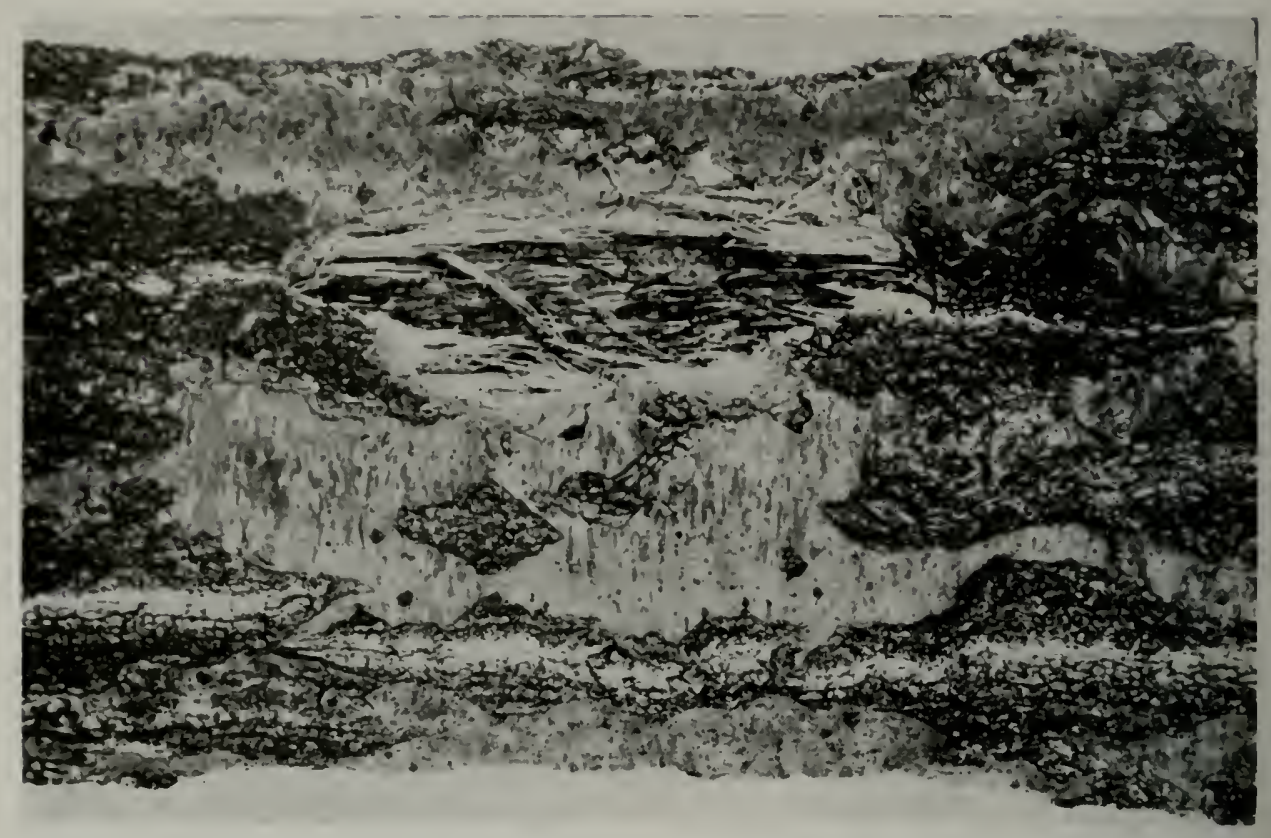

Fig. 17.-Damage inflicted by squirrel or squirrels to the bark of an oak tree and the underlying mycelial pad of Endoconidiophora fagacearum.

cycle of the fungus. The destructive feeding habits of some of these insects, particularly the Nitidulidae, on laboratory cultures of Endoconidiophora fagacearum were mentioned earlier, page 297. Also, the role of some insects in the destruction of mats in the field was observed, fig. $16 \mathrm{~A}$.

During the spring three immature mats, which had no insects on them when examined, were covered with clean plastic covers so that no insects could reach the fungus; then the bark, which had been removed for the examination, was replaced over the mats and nailed securely to the trees. 'Three other immature mats, which had several individuals of both Glischrochilus obtusus and Colopterus truncatus present, were covered in the same manner.

The mats on which no insects had been seen remained in good condition for between 4 and 6 weeks, after which contamination by bacteria and fungi other than Endoconidiophora fagacearum was evident. The mats with insects present declined rapidly, reaching a stage of complete deterioration in 2 weeks. It was observed that, throughout the spring and summer, mats infested by large numbers of Nitidulidae deteriorated rapidly. During the winter months, when insect activity was low, mats lasted much longer.

Another role in which insects may be important is that of spermatizing mats with conidia of opposite compatibility groups, as shown experimentally by Leach et al. (1952) with two species of Nitidulidae and one of Orthropidae. Any of the species of insects listed in table 13, or even mites, might conceivably perform this role.

At least 3 of the 40 or more species of insects that were found on mats were present during each of the winter months as well as in the spring and summer, table 13. Several species were prevalent in October and November. During the cold months of January and February only 3 species were constantly associated with the mats; these were adults of the order Collembola and Glischrochilus obtusus and larvae of Carpophilus sp., which were usually present in large numbers throughout the 10-month period. Although Carpophilus larvae were often found embedded in ice on the mats, many of them survived and, on warm days, fed on the fun- 
gus. In winter months, Glischrochilus obtusus was present usually only in small numbers of 1 to 10 per mat.

In April, large numbers of adult Scolytidae were seen running over the bark surface or making holes through the bark of diseased oaks that were near the mat-pro- ducing stage. Later, in May and June, many holes made by these beetles were seen in the wood and bark of most of the mat-bearing trees. It was common to find several holes extending through mycelial mats beneath the bark, fig. $16 B, C$. Many of these holes had been made directly
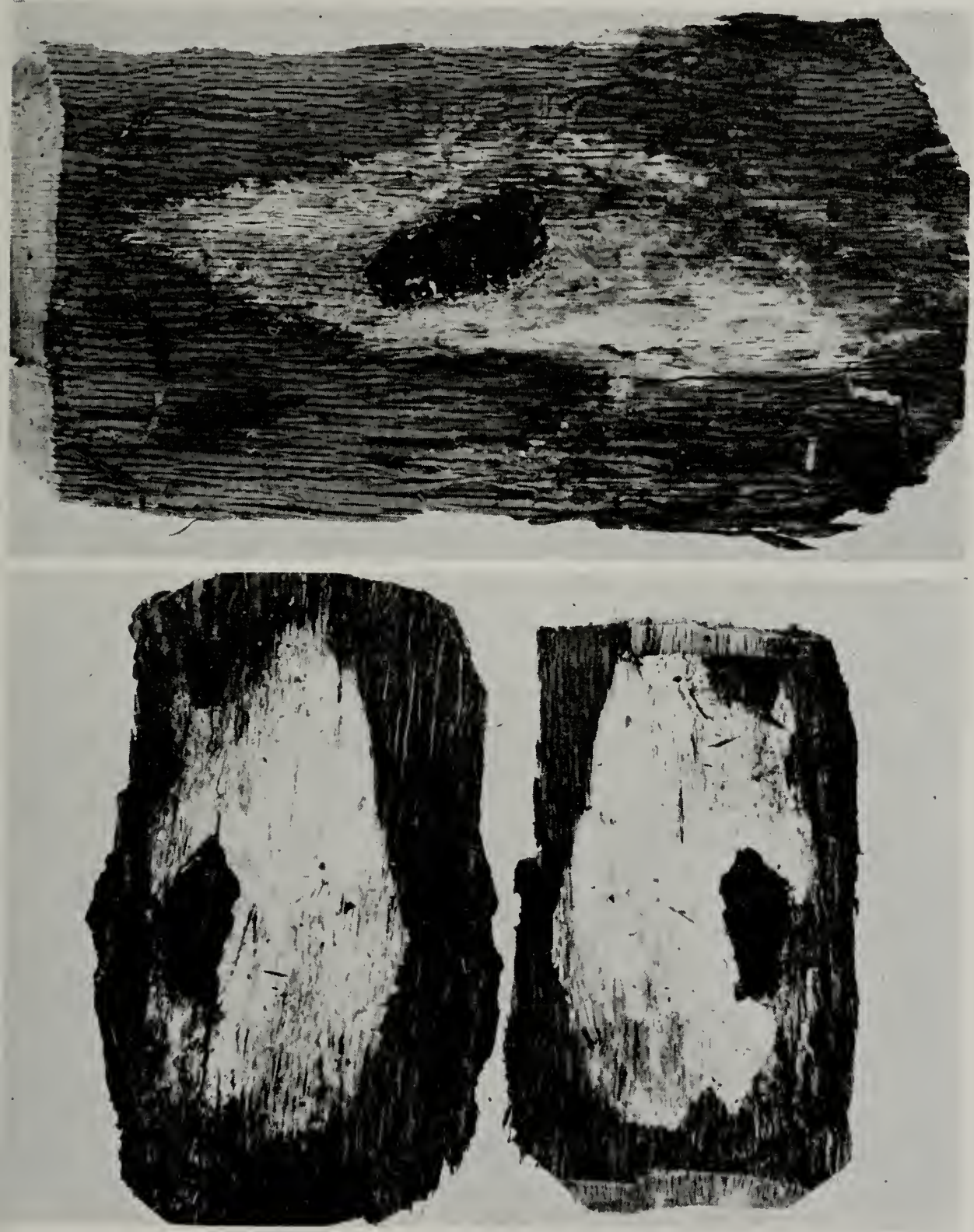

Fig. 18.-Mats of Endoconidiophora fagacearum on which unidentified fungi bave overrun all but the central pads. 
through the central pads, fig. $16 D$, and some beetles were found embedded there.

Insect activity on mats was greatest during April, May, and June, when more species were found than in any other months. Very few fresh mats were found in July, and insects were seldom found on them.

Few attempts were made to determine exact numbers of insects on mats. Members of the families Nitidulidae, Staphylinidae, and Histeridae, and of the order Collembola, obviously were inuch more abundant than any of the others. Approximately 75 to 100 adult Nitidulidae and as many larvae were commonly seen on a single mat. Members of the Staphyinidae and of the Collembola, which are much smaller than the Nitidulidae, were even more numerous. Adult insects were found most frequently on class III and class IV mats and larvae on class IV and class $V$ mats, table 14 . Insects were se!dom present on immature mats, as the cracks in the bark over such mats usually were very narrow, barely perceptible openings that could admit only the smallest insects. Small individuals of the Nitidulidae were often seen making unsuccessful attempts to squeeze through these openings. The fact that immature (class I) mats are not so strongly odoriferous as are mats of the mature and aging classes also may account for the presence of fewer insects on the younger mats.

\section{Other Agents Associated With Mats}

Agents other than insects may have been responsible for hastening the decline and deterioration of natural reservoirs of inoculum. Feeding by rodents on mycelial mats of Endoconidiophora fagacearum in Pennsylvania was reported by Morris \& Fergus (1952). Squirrels caused considerable damage to mycelial mats in Illinois (Himelick et al. 1953) during the winter of 1952-53, and new damage of this kind, fig. 17, was seen in May and June of 1953. The rodents seemed to have been interested in only the central pads of young mats, but, to reach the pads, they had torn large holes in the bark, exposing the fungus to other destructive elements, such as insects, wind, rain, and other fungi.
During the summer months, the matbearing trees were often exposed to the direct rays of the sun, and temperatures became very high under the bark. The temperatures for one tree at 3:00 p.m. on July 23, 1953, were 32.5 degrees outside and 41.0 degrees under the bark on the sunny side of the trunk, as determined by actual thermometer readings. On the shaded side, the temperatures were 29.5 degrees outside and 30.5 degrees beneath the bark. No further mat production occurred on this tree, and the fungus could not be isolated from the wood. During the winter months, mats were subjected to alternate freezing and thawing. At this time the mats often were continuously wet for several days and finally became slimy with bacteria and other microscopic forms of life.

Many mycelial mats were found to be overrun by wood-rotting fungi, fig. 18 , except for the central pad of each, which seemed to repel invasion of these fungi. However, the pads were readily attacked by other fungi. Graphium, in particular, throve well in aging pads, where it entangled the pad cells in a thick mass of hyphal strands and produced abundant coremia and slimy masses of spores.

Other agents that were commonly associated with the mats of the oak wilt fungus but that were less destructive were mites, nematodes, and crustacea. Mites were usually abundant during all months on mats in all stages of decline. Nematodes of the genus Diplogaster* were very abundant on old perithecium-bearing mats. They infested the masses of exuded ascospores of Endoconidiophora fagacearum, in some cases hundreds in a single mass. These nematodes had oral openings that measured about 5.6 microns, large enough to admit conidia or ascospores of the oak wilt fungus. However, attempts to entice the nematodes to feed upon the spores of the fungus on the surface of agar were unsuccessful. Crustaceans of the species Porcellio rathkei were sometimes found on mycelial mats that had developed on bark pieces on the forest floor, but they were not observed feeding on the fungus of the oak wilt disease.

* Nematodes were identified by Dr. M. B. Linford, Department of Horticulture, University of Illinois. 


\section{INOCULA IN NATURE}

\section{Sources of Data}

A total of 629 mycelial mats of Endoconidiophora fagacearum were found beneath the bark of 27 of the 30 wilt-killed oaks that were thoroughly studied over a 10 -month period, table 10 . The remaining 3 trees, 1 standing white oak, 1 standing bur oak, and 1 felled black oak, did not produce mats. Twenty additional mats were taken from 4 red oaks that were examined only once and that were not included among the thoroughly studied trees. These 20 mats brought the total number of mats found on 31 mat-bearing trees to 649 . The figure for mats includes only typical mats with central pads accompanied by cracks in the bark.

The detailed data presented on the following pages were obtained from 365 , or 56 per cent, of the total number of mats found. Forty-three of these mats were left on the trees, where each was resampled at 2-week intervals until it reached a deteriorated condition. The total number of additional samplings* that were made of the 43 mats on the trees was 100. Thus, the data came from 465 samplings of 365 mats, table 15. As each additional sampling of a mat was made at a later

* A samplirig involved taking three mycelial disks each $7 \mathrm{~mm}$. in diameter from a mat, as described on page 284 . time than the one preceding and when the mat was more advanced in its development or decline, the data obtained from this sampling were treated as if taken from a separate mat. The figures in table 15 represent mats sampled in all five study areas. More samples were taken during the spring and summer than at other periods of the year, because more mats were produced at that time. Also, more mats of classes IV and $V$ than of other classes were sampled, as they were found more often than mats of the other classes.

\section{Availability of Conidia}

The data regarding numbers and germinability of conidia obtained from samples of naturally occurring mycelial mats of the oak wilt fungus in their different stages of development and decline during 10 months are presented in table 16 . The method of counting and germinating conidia is described in another section, "Treatment of Samples From Nature," page 296.

The average number of conidia per mat, as determined from mats of all classes, increased from October to December, 1952, at which time the highest concentration of the 10 -month period was reached, fig. 19. The concentration of conidia then decreased steadily during a period of low winter and spring tempera-

Table 15.-Numbers of samplings and average sizes (cm.) of mycelial mats of Endoconidiophora fagacearum in five condition classes* sampled in the 10 -month period October, 1952 , through July, 1953.

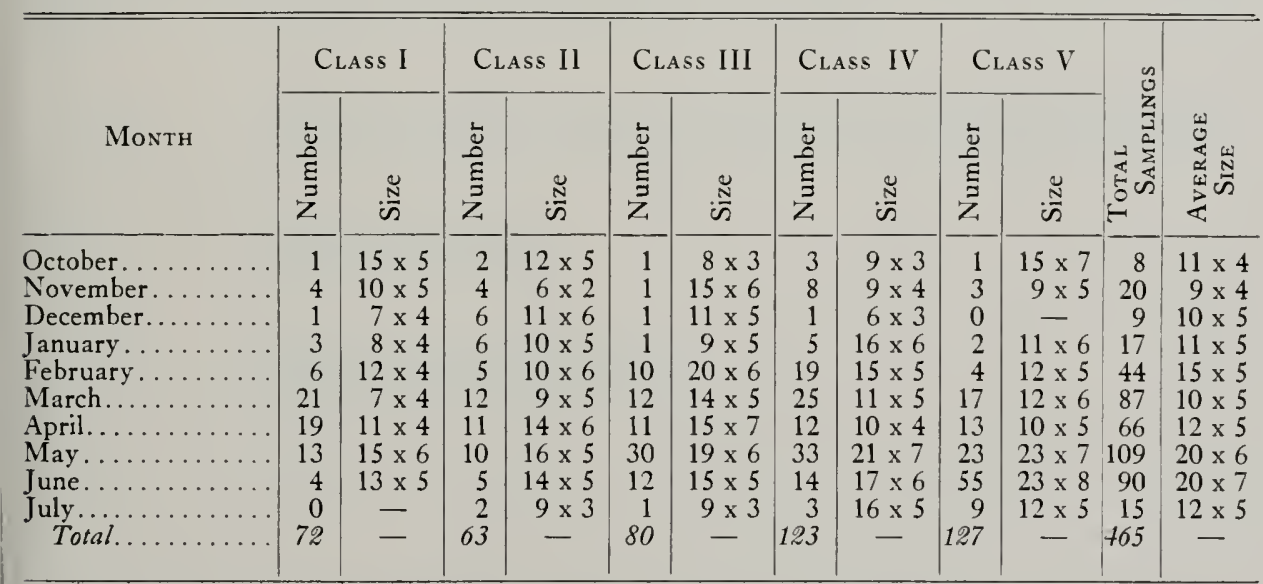

*Condition class I, immature; II, mature; III, aging; IV, declining; V, deteriorating. 
tures until April, 1953, when a sharp rise occurred with a rise in monthly mean temperature. After April, the number of conidia decreased again, as the monthly mean temperatures increased, and no conidia were found on mats that were sampled in July. It is interesting to note in fig. 19 that the peak in conidium concentration in December and a rise in April were preceded by months in which precipitation was above the annual mean.

The time of the highest average per

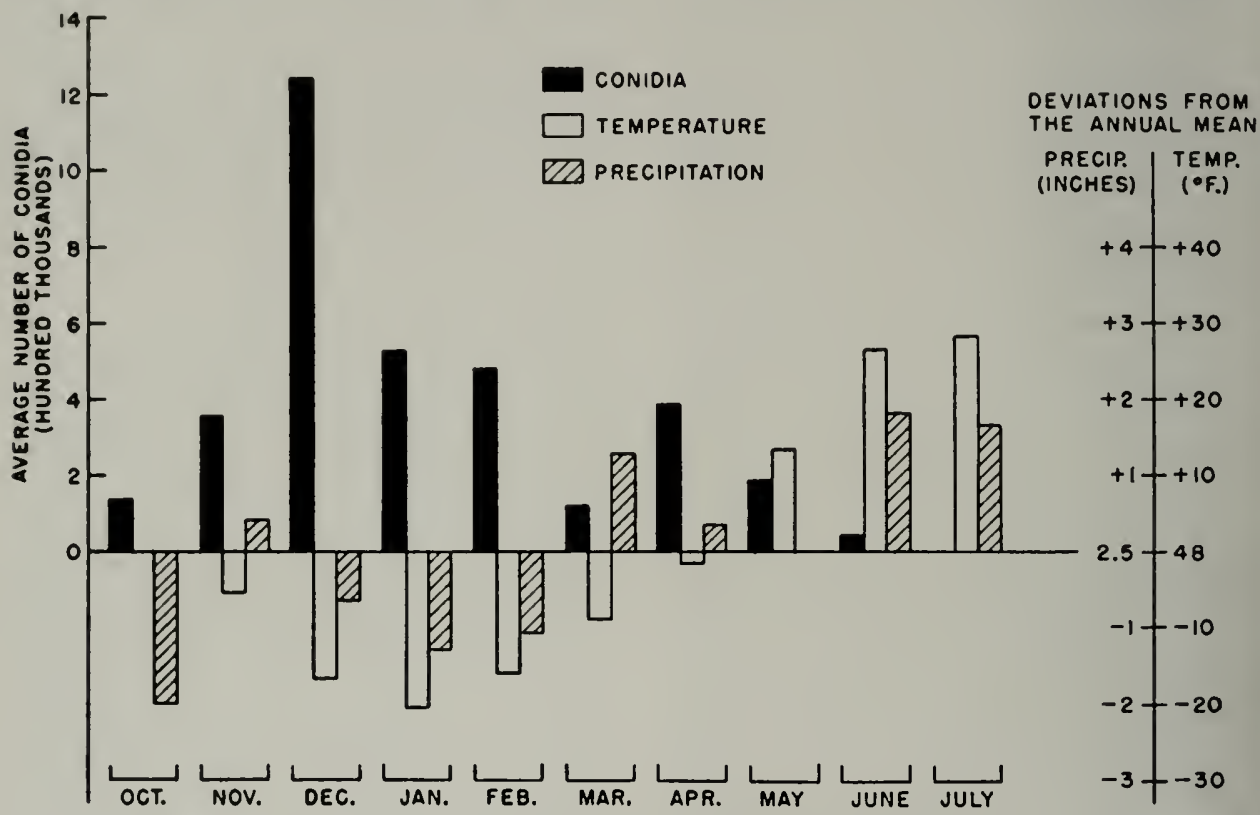

Fig. 19.-Monthly mean temperature and total precipitation, both shown as deviations from the annual means, and average numbers of conidia (per $\mathrm{ml}$. of spore suspension prepared from three-disk sampling of each mat) obtained from samples of mycelial mats of Endoconidiophora fagacearum, October, 1952, through July, 1953. For temperature in October and for precipitation in May there were no deviations from the means.

Table 16.-Average number per mat sample* and per cent germination of conidia taken from naturally occurring mats of Endoconidiophora fagacearum in five condition classest in the 10-month period October, 1952, through July, 1953.

\begin{tabular}{|c|c|c|c|c|c|c|c|c|c|c|}
\hline \multirow[b]{2}{*}{ MoNTH } & \multicolumn{2}{|c|}{ Class I } & \multicolumn{2}{|c|}{ Class II } & \multicolumn{2}{|c|}{ Class III } & \multicolumn{2}{|c|}{ Class IV } & \multicolumn{2}{|c|}{ Class $V$} \\
\hline & 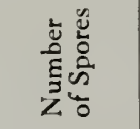 & 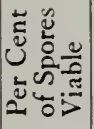 & z⿺辶ّ & 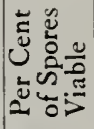 & 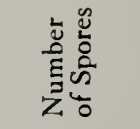 & 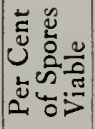 & 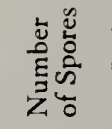 & 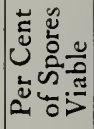 & 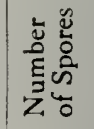 & 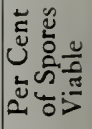 \\
\hline ctol & 84,800 & 58 & 511,150 & 15 & 0 & - & 0 & - & 0 & - \\
\hline & $1,079,675$ & 67 & 608,125 & 23 & 106,600 & 10 & 29,875 & 5 & 0 & 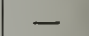 \\
\hline De & 122,600 & 2 & $1,646,333$ & 4 & $1,056,000$ & 1 & 133,000 & 0 & 0 & - \\
\hline & 533,000 & 12 & 550,433 & 26 & 320,000 & 0 & 741,120 & 11 & 0 & - \\
\hline & 19,442 & 0 & 60,740 & 10 & 585,410 & 4 & 76,453 & 0 & 21,250 & 0 \\
\hline & 413,786 & 56 & 70,875 & 13 & 25,688 & i & 12,822 & 1 & 3,724 & 0 \\
\hline & 197,708 & 61 & 404,464 & 34 & 813,455 & 40 & 135,583 & 6 & 0 & - \\
\hline & 488,385 & 39 & 407,400 & 6 & 266,527 & 9 & 58,606 & 1 & 0 & - \\
\hline & 152,000 & 67 & 78,000 & 15 & 52,000 & $y$ & 40,914 & 5 & 436 & 15 \\
\hline & & - & & - & & - & & - & 0 & - \\
\hline
\end{tabular}

- Figures are calculated averages. Numbers of mat samplings are shown in table 15.

$\uparrow$ Condition class I, immature; II, mature; III, aging; IV, declining; V, deteriorating. 
Table 17.-Average number per mat sample* and per cent germination of conidia taken from mycelial mats of Endoconidiophora fagacearum in five condition classest in five study areas in the 10-month period October, 1952, through July, 1953.

\begin{tabular}{|c|c|c|c|c|c|c|c|c|c|c|c|c|c|c|c|}
\hline \multirow[b]{2}{*}{$\begin{array}{c}\text { Study } \\
\text { AREA }\end{array}$} & \multicolumn{3}{|c|}{ CLASS I } & \multicolumn{3}{|c|}{ Class II } & \multicolumn{3}{|c|}{ Class III } & \multicolumn{3}{|c|}{ Class IV } & \multicolumn{3}{|c|}{ ClasS $_{\text {L }}$} \\
\hline & 点 &  & 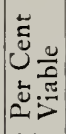 & 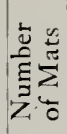 & 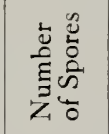 & 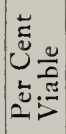 & 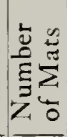 & 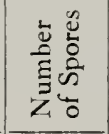 & 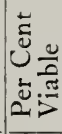 & 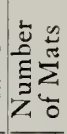 & 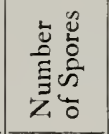 & 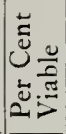 & 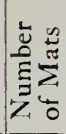 & 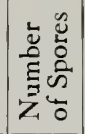 & 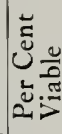 \\
\hline $\begin{array}{l}\text { Chicago... } \\
\text { Sinnissippi. } \\
\text { Rockford. } \\
\text { Peoria.... } \\
\text { Havana... }\end{array}$ & $\begin{array}{l}11 \\
12 \\
14 \\
20 \\
15\end{array}$ & $\begin{array}{l}144,782 \\
335,842 \\
500,011 \\
289,698 \\
481,860\end{array}$ & $\begin{array}{l}51 \\
49 \\
51 \\
51 \\
53\end{array}$ & $\begin{array}{r}16 \\
14 \\
17 \\
11 \\
5\end{array}$ & $\begin{array}{l}129,156 \\
326,421 \\
839,371 \\
371,009 \\
343,180\end{array}$ & $\begin{array}{l}19 \\
10 \\
10 \\
33 \\
18\end{array}$ & $\begin{array}{r}9 \\
17 \\
24 \\
19 \\
11\end{array}$ & $\begin{array}{r}67,956 \\
371,097 \\
281,083 \\
421,158 \\
322,227\end{array}$ & $\begin{array}{r}7 \\
12 \\
9 \\
20 \\
12\end{array}$ & $\begin{array}{l}14 \\
24 \\
48 \\
16 \\
21\end{array}$ & $\begin{array}{r}19,643 \\
74,288 \\
117,778 \\
56,438 \\
65,252\end{array}$ & $\begin{array}{l}1 \\
3 \\
3 \\
5 \\
2\end{array}$ & $\begin{array}{l}26 \\
12 \\
46 \\
28 \\
15\end{array}$ & $\begin{array}{r}923 \\
4,442 \\
2,065 \\
0 \\
0\end{array}$ & $\begin{array}{r}15 \\
0 \\
0 \\
- \\
-\end{array}$ \\
\hline
\end{tabular}

* Figures are calculated averages.

$\dagger$ Condition class I, immature; II, mature; IJI, aging; IV, declining; V, deteriorating.

OCTOBER

NOVEMBER


DECEMBER

JANUARY

\section{FEBRUARY}

\section{MARCH}

APRIL

MAY

JUNE
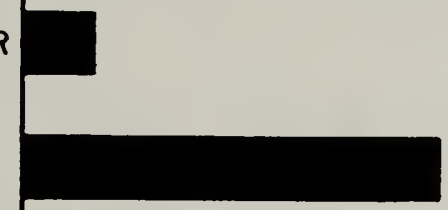

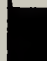

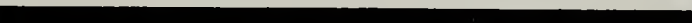


cent germinability of conidia taken from meclial nats during the 10 -month period did not coincide with the time of highest concentration of conidia. The best average germination rate (39 per cent) was obtained from conidia that were collected in April, fig. 20. The next best germination rate was obtained from conidia collected in November. A germination rate as high as 80 per cent was not uncommon.

'The number and germinability" of conidia that were taken from mats of the same condition class did not vary unexpectedly from one study area to another, table 17. All areas included in the study were in the northern half of the state, and the distance between any two areas was not greater than 165 miles.

Pronounced differences were found, in the number and germinability of conidia, between the mats belonging to different condition classes, fig. 21. The highest average numbers of conidia were obtained from mature, or class 11 , mats. The highest average per cent of germination oc- curred in conidia from inmature, or class I, mats. Both the number and germinability of spores changed as the condition of the mats advanced from class I toward class $V$ or deterioration.

The data dealing with number of conidia on a mat were based upon estimates of the average number of spores in $1 \mathrm{ml}$. of suspension prepared from a 3-disk sampling of the mat. A rough approximation of the number of conidia on an entire mat could be made by using figures obtained from the samples. The number of conidia in a mature mat which measured 12 by $5 \mathrm{~cm}$. with a central pad which measured 4 by $2 \mathrm{~cm}$. was estimated as follows. The average number of conidia from one disk of mat surface $7 \mathrm{~mm}$. in diameter (3S sq. mm.) contained in $1 \mathrm{ml}$. of a $10-\mathrm{ml}$. water blank was 350,000 spores or $3,500,000$ spores from the entire disk. The area of the mat, after the area of the central pad (which had few or no spores) had been deducted, was,+ 100 square $\mathrm{mm}$. The number of conidia on

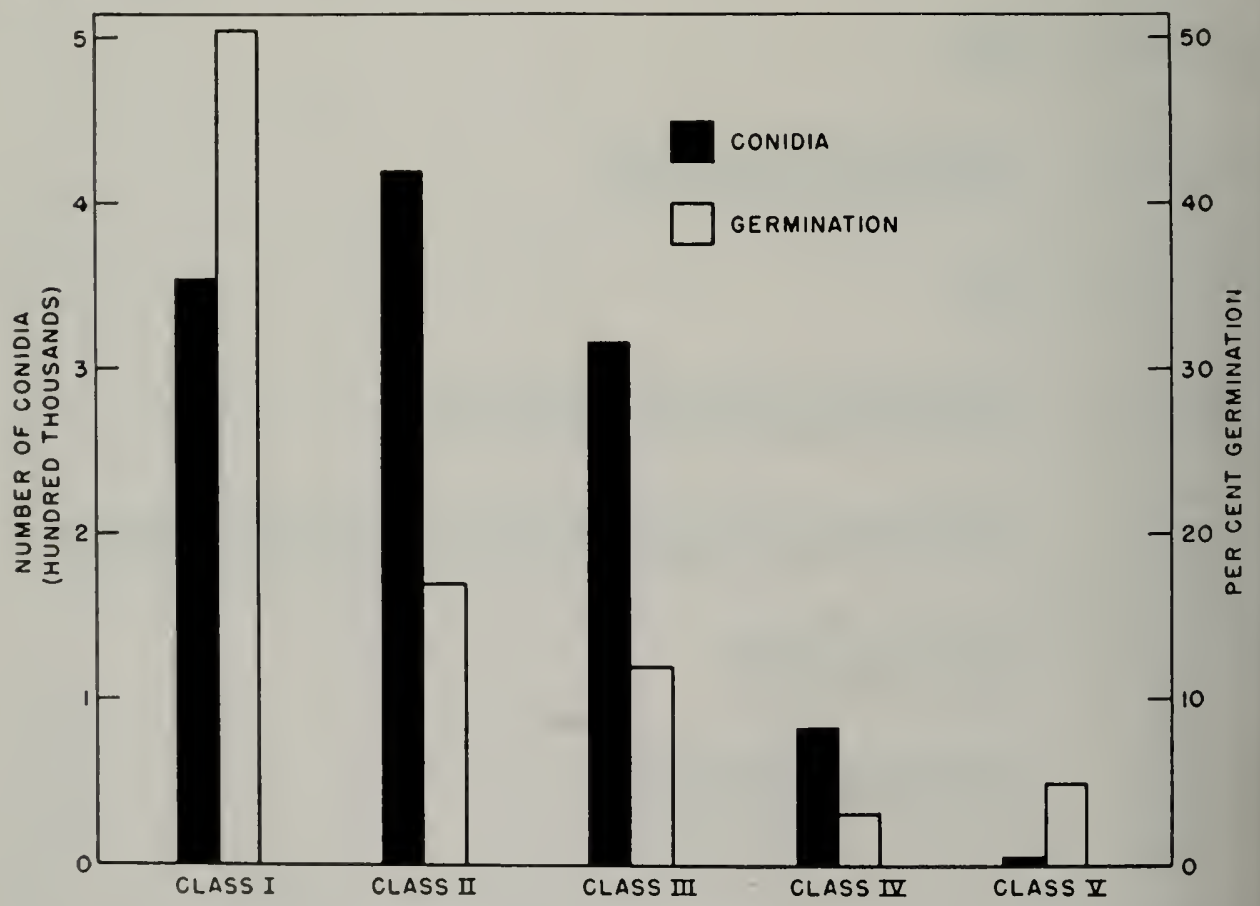

Fig. 21.-Average number and per cent germination of conidia of Endoconidiophora fagacearum taken from mycelial mats in five stages of development and decline over the 10 month period October, 1952, through July, 1953; class I, immature; class II, mature; class III, aging; class IV, declining; class $\mathrm{V}$, deteriorating. 
the entire mat was estimated as being approximately 378,000,000. Another mat which measured $2+$ by $10 \mathrm{~cm}$., the pad 6 by $2 \mathrm{~cm}$., and which had the same average number of spores on a disk sample as the mat above, was estimated to have 1,650,000,000 conidia, more than four times as many as the other mat.

From these figures one can appreciate the significance of mat size as well as numbers of mats in accounting for the concentration of conidia in an oak wilt area. It can be seen in table 15, which gives the average sizes of all mats sampled in each month, that the mats of May and June were considerably larger than those of other months. The sizes of the mats sampled in all months ranged from 1 by $1 \mathrm{~cm}$. to 48 by $14 \mathrm{~cm}$.

As pointed out earlier, other possible mycelial sources of oak wilt inoculum might be afforded by the padless mycelial mats that form on bark pieces on the forest floor and by wound-stimulated mycelial growth on standing and felled trees. The conidial sporulation on such mats and the ability of the spores to germinate appear to be equal to those of typical mats with pads, table 18 .

\section{Availability of Fertile Perithecia}

The total number of mats found with perithecia during the 10 -month study period was 90 , or 23 per cent of 393 mats studied in detail, table 19 . Perithecia were never present on class I mats. The month with the highest percentage of perithecium-bearing mats was December and the next highest May.

Table 18.-Average number and serminability of conidia of Endoconidiophora fagacearum obtained from wound-stimulated mycelial mats and from mats on bark pieces on the forest floor during 3 months of 1953.

\begin{tabular}{|c|c|c|c|c|c|c|}
\hline \multirow[b]{2}{*}{ Month } & \multicolumn{3}{|c|}{ Wound-Stimulated Mats } & \multicolumn{3}{|c|}{ Mats on Bark on Ground } \\
\hline & $\begin{array}{l}\text { Number } \\
\text { of Mats } \\
\text { Sampled }\end{array}$ & $\begin{array}{l}\text { Average } \\
\text { Number } \\
\text { of } \\
\text { Conidia }\end{array}$ & $\begin{array}{l}\text { Per Cent } \\
\text { of } \\
\text { Conidia } \\
\text { Viable }\end{array}$ & $\begin{array}{l}\text { Number } \\
\text { of Mats } \\
\text { Sampled }\end{array}$ & $\begin{array}{c}\text { Average } \\
\text { Number } \\
\text { of } \\
\text { Conidia }\end{array}$ & $\begin{array}{c}\text { Per Cent } \\
\text { of } \\
\text { Conidia } \\
\text { Viable }\end{array}$ \\
\hline $\begin{array}{l}\text { March.... . } \\
\text { April. . . . . } \\
\text { May ... . . }\end{array}$ & $\begin{array}{r}2 \\
16 \\
6\end{array}$ & $\begin{array}{r}480,000 \\
279,000 \\
72,000\end{array}$ & $\begin{array}{r}35 \\
34 \\
9\end{array}$ & $\begin{array}{r}4 \\
13 \\
-\end{array}$ & $\begin{array}{r}256,000 \\
38,500 \\
-\end{array}$ & $\begin{array}{l}56 \\
17 \\
-\end{array}$ \\
\hline
\end{tabular}

Table 19.-Perithecium-bearing mycelial mats of Endoconidiophora fagacearum in four condition classes* found on wilt-killed oaks in the 10-month period October, 1952, through July, 1953.

\begin{tabular}{|c|c|c|c|c|c|c|c|c|c|}
\hline \multirow[b]{2}{*}{ Month } & \multicolumn{2}{|c|}{ Class II } & \multicolumn{2}{|c|}{ Class $11 \mathrm{I}$} & \multicolumn{2}{|c|}{ Class IV } & \multicolumn{2}{|c|}{ Class $V$} & \multirow[b]{2}{*}{ 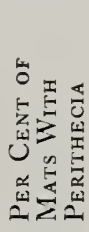 } \\
\hline & 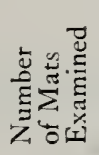 & 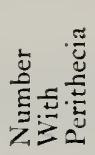 & 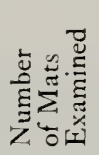 & 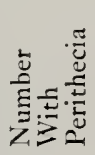 & 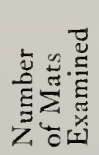 & 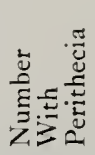 & 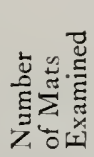 & 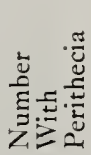 & \\
\hline 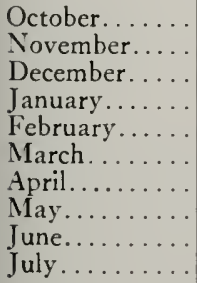 & $\begin{array}{r}2 \\
4 \\
6 \\
6 \\
5 \\
12 \\
11 \\
10 \\
5 \\
2\end{array}$ & $\begin{array}{l}2 \\
1 \\
3 \\
0 \\
1 \\
0 \\
1 \\
3 \\
2 \\
0\end{array}$ & $\begin{array}{r}1 \\
1 \\
1 \\
1 \\
10 \\
12 \\
11 \\
30 \\
12 \\
1\end{array}$ & $\begin{array}{r}0 \\
0 \\
1 \\
1 \\
1 \\
0 \\
2 \\
21 \\
3 \\
0\end{array}$ & $\begin{array}{r}3 \\
8 \\
1 \\
5 \\
19 \\
25 \\
12 \\
33 \\
14 \\
3\end{array}$ & $\begin{array}{r}0 \\
1 \\
0 \\
4 \\
7 \\
2 \\
1 \\
18 \\
8 \\
0\end{array}$ & $\begin{array}{r}1 \\
3 \\
0 \\
2 \\
4 \\
17 \\
13 \\
23 \\
55 \\
9\end{array}$ & $\begin{array}{l}0 \\
0 \\
0 \\
0 \\
1 \\
2 \\
0 \\
0 \\
4 \\
0\end{array}$ & $\begin{array}{r}29 \\
13 \\
50 \\
36 \\
26 \\
6 \\
9 \\
44 \\
20 \\
0\end{array}$ \\
\hline
\end{tabular}


The average number of perithecia on a $6 \mathrm{~mm}$. square area of mat surface and the average germinability of ascospores are presented by months and by mat classes in table 20. Some mature mats had many young perithecia not exuding ascopores,

Table 20.-Average numbers of perithecia on $6 \cdot \mathrm{mm}$. square areas of surface on perithecium-bearing mats of Endoconidiophora fagacearum in four condition classes* and per cent germination of ascospores in the 9-month period Oetober, 1952, through June, 1953.

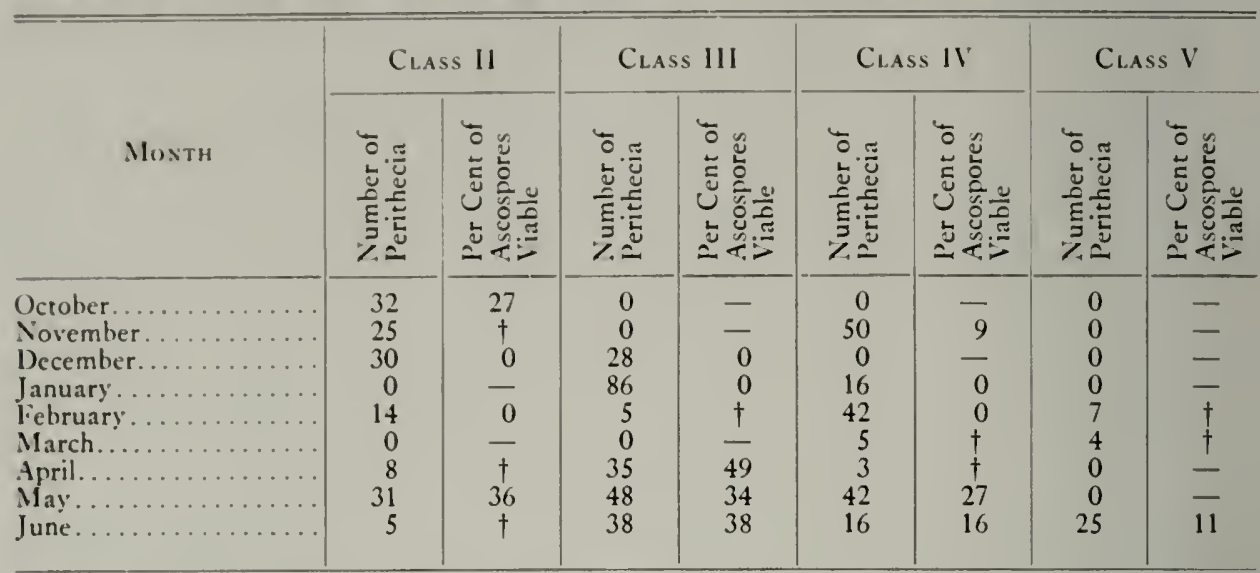

- Condition class 11, mature; III, aging; IV, declining: V, deteriorating.

t Because the surface was infested with nematodes, bacteria, and Graphium sp., it could not be told with certainty whether the ascospores had germinated.
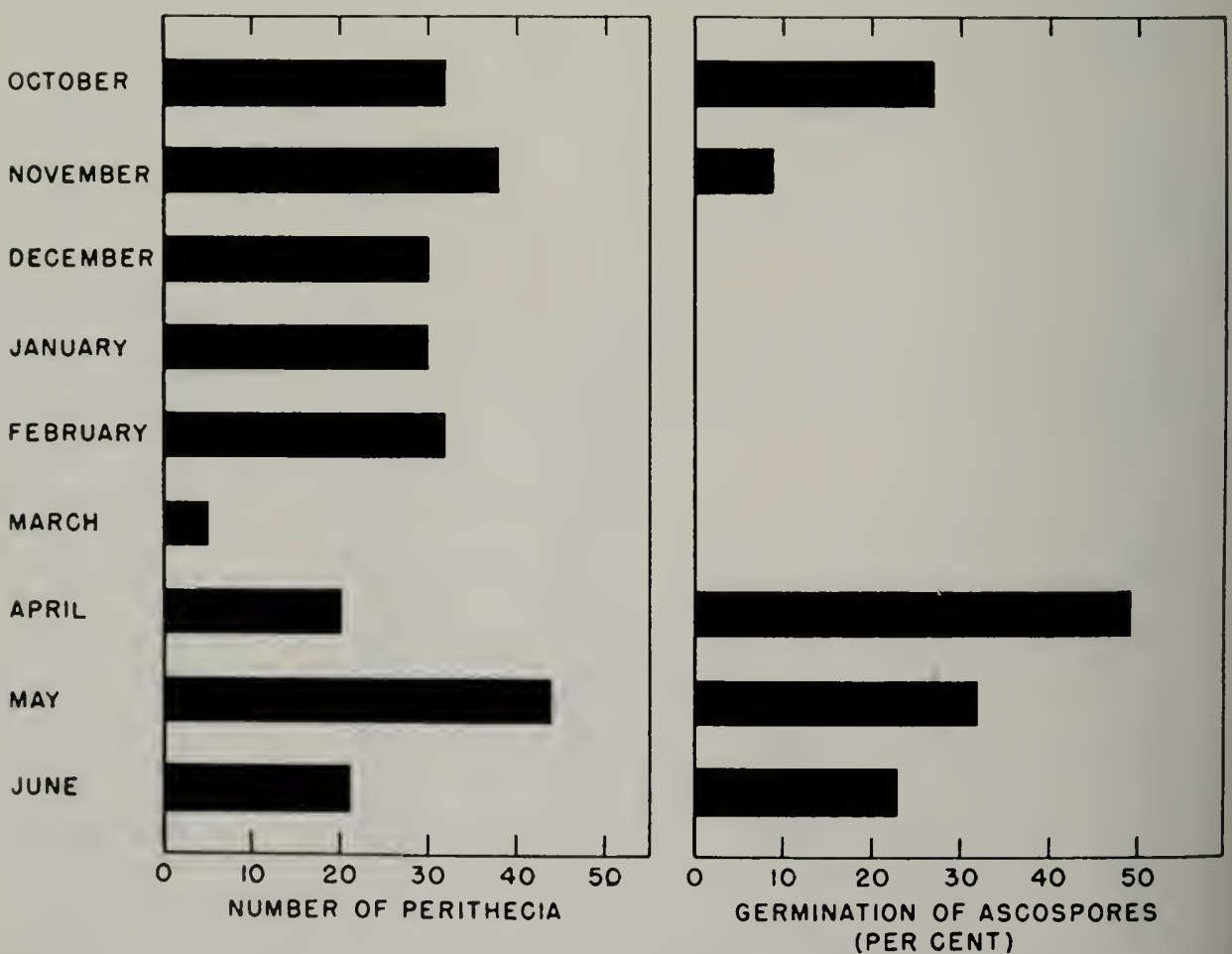

Fig. 22.-Average number of perithecia on a $6-\mathrm{mm}$. square area of mat surface and average per cent germination of ascospores taken from mycelial mats of Endoconidiophora fagacearum, October, 1952, through June, 1953. 
Table 21.-Per cent of mats of Endoconidiophora fagacearum with perithecia, average number of perithecia on a $6-\mathrm{mm}$. square area of mat surface, and average per cent germination of ascospores ( 465 mat samplings in five condition classes*).

\begin{tabular}{|c|c|c|c|}
\hline $\begin{array}{l}\text { Condi- } \\
\text { TION } \\
\text { Class }\end{array}$ & $\begin{array}{c}\text { PER CENT } \\
\text { OF MATS } \\
\text { IVITH } \\
\text { PER- } \\
\text { ITHECIA }\end{array}$ & $\begin{array}{l}\text { NUMBER } \\
\text { OF PER- } \\
\text { ITHECIA ON } \\
\text { 6-MM. } \\
\text { SQUARE } \\
\text { AREA OF } \\
\text { MAT } \\
\text { SURFACE }\end{array}$ & $\begin{array}{c}\text { PER } \\
\text { CENT } \\
\text { GERMI- } \\
\text { NATION OF } \\
\text { ASCO- } \\
\text { SPORES }\end{array}$ \\
\hline $\begin{array}{l}\text { Class I. . . } \\
\text { Class II . . } \\
\text { Class III . } \\
\text { Class IV... } \\
\text { Class V.... }\end{array}$ & $\begin{array}{r}0 \\
21 \\
36 \\
33 \\
6\end{array}$ & $\begin{array}{r}0 \\
23 \\
45 \\
32 \\
16\end{array}$ & $\begin{array}{r}0 \\
16 \\
33 \\
17 \\
11\end{array}$ \\
\hline
\end{tabular}

* Condition class I, immature; II, mature; III, aging; IV, declining; $\mathrm{V}$, deteriorating.

Table 22.-Numbers and per cents of positive cultures obtained by mass transfers of pad cells from mycelial mats of Endoconidiophora fagacearum in five condition classes* over the 10 -month period October, 1952, through July, 1953.

\begin{tabular}{c|c|c|c}
\hline \hline $\begin{array}{c}\text { Condi- } \\
\text { tion } \\
\text { Class }\end{array}$ & $\begin{array}{c}\text { Number } \\
\text { Of Pads } \\
\text { Sampled }\end{array}$ & $\begin{array}{c}\text { Number } \\
\text { Giving } \\
\text { Positive } \\
\text { Cultures }\end{array}$ & $\begin{array}{c}\text { Per Cent } \\
\text { Giving } \\
\text { Positive } \\
\text { Cultures }\end{array}$ \\
\hline Class I ...... & 68 & 56 & 82 \\
Class II ..... & 57 & 24 & 42 \\
Class III.... & 64 & 16 & 25 \\
Class IV ..... & 112 & 0 & 0 \\
Class V...... & 122 & 0 & 0 \\
& & & \\
\hline
\end{tabular}

* Condition class I, immature; II, mature; III, aging; $\mathrm{IV}$, declining; $\mathrm{V}$, deteriorating.

and many old mats had masses of ascospores infested by nematodes, bacteria, and spores of fungi other than Endoconidiophora fagacearum. In neither of these types of mats were ascospore germination tests possible.

The average number of perithecia per mat sample and the average percentage of ascospores germinating in four mat classes are treated graphically by months in fig. 22. Perithecia were found in all months except July; the largest average number per mat sample, 44 , was found in May. However, germination of ascospores was obtained only in October, November, April, May, and June. The best average germination rate was 49 pcr cent, obtained with ascospores collected in
April; 32 per cent germination was obtained with ascospores collected in May. In some cases, as high as 83 per cent of the ascospores germinated.

Like conidia, perithecia and ascospores were strikingly influenced by the extent of mat development or decline, table 21. Of 465 mat samplings in all areas and all months of the study period, class III, aging mats, had the highest percentage with perithecia, 36 per cent. Mats of this class contained the greatest number of perithecia, an average of 45 on a $6 \mathrm{~mm}$. square area of mat surface, and they had the highest rate of germinating ascospores, 33 per cent. Mats frequently had as many as 90 perithecia on a sample 6 mm. square.

\section{Mycelial Pads}

A potential source of oak wilt inoculum which should not be overlooked is that afforded by the highly germinable cells that comprise the central pads of mycelial mats. The ability of these cells to germinate and produce large numbers of conidia was shown in laboratory studies.

From October, 1952, through July, 1953, 423 mycelial pads on mats of all five condition classes were sampled in the field. The results of mass transfers from the interiors of these pads to potato dextrose agar are given in table 22. Eightytwo per cent of the pads from class I mats, 42 per cent of the pads from class II mats, and 25 per cent of the pads from class III mats gave positive cultures of Endoconidiophora fagacearum. The living fungus was never isolated from pads of class IV and class $V$ mats.

\section{DISCUSSION}

The present study has shown that three potential oak wilt inocula are present in nature in Illinois. These are conidia, ascospores, and mycelial pad cells, all of which are furnished by the macroscopic subcortical fruiting mats of Endoconidiophora fagacearum on wilt-killed oaks. The mats on which conidia and perithecia form develop readily on both standing diseased trees and trees felled after symptoms have appeared. Additional conidium inoculum may be created by the formation of padless mycelial mats adjacent to 
wounds on mat-producing trees and on the inner sides of pieces of bark from diseased trees while these pieces lie on the moist forest floor. Perithecia were never found on such mats.

It was well known before the present study was undertaken that the injection of either conidia or ascospores of Endoconidiophora fagacearum into healthy oaks would result in diseased trees. However, it was not realized that the irregularly shaped cells that constitute the pseudoparenchymatous interiors of mycelial pads are capable of rapid germination and abundant sporulation comparable to that of conidia and ascospores. Like conidia and ascospores, the pad cells germinate well on plain water agar, but whether they will germinate and produce oak wilt symptoms when injected into healthy oak trees has not been determined. It has been shown that cultures obtained from pad cells are pathogenic. Pad cells do not seem to be adapted for insect transmission, but the possibility of their spread by squirrels or woodpeckers is not remote. While woodpecker damage to mycelial mats has not been observed in Illinois, damage caused by the feeding of squirrels is common. The spread of fungus diseases by these and other unusual agents has been reported by Gravatt \& Marshall (1917), Heald \& Studhalter (1914), and Talbot (1952).

The decline of diseased oak trees and the development and decline of the resulting mycelial mats seem to follow a pattern. "The brown streaks that are normally found in diseased trees of the red oak group first become more pronounced, usually on one side of the tree; then they increase in width and length until a large area of wood is brown. During this process the bark loses its tight grip on the wood, which begins to emit the characteristic amyl acetate or ripe fruit odor of the fungus. Now having "room" to grow, the fungus appears in a macroscopic form, in most cases in a few days. The time required for the conditioning process to occur before mats appear is dependent on the season of the year. In lllinois the first wilt symptoms of the year are seen on trees early in June. 'Trees wilting at this time decline rapidly and may produce mats late in August or in September. The decline of trees that wilt in the last part of July or in August is retarded by low winter temperatures, and these trees may not produce mats until the following spring or summer, unless the winter is unusually mild. Mycelial mats of Endoconidiophora fagacearum have not been reported on trees of the white oak group in Illinois. 'The bark on diseased white oaks is thin and adheres to the wood, even after the trees have reached an advanced stage of decline. No ripe fruit odor was detected in the white oaks studied.

In the period of this studs, more mats were found during April, May, and June than in other months. These months were the ones during which large numbers of bark beetles (Scolytidae) were boring hundreds of tiny holes through the bark and wood of wilt-killed trees. Such perforating of the bark mav have been instrumental in bringing about a subcortical aeration that resulted in a condition favorable for rapid mat development. The inducement of mat formation by intentional wounding of trees that were nearing the mat-producing condition indicated that a supply of air from outside may hasten mat initiation. When the wood surface of mat-producing trees was covered with plastic, the fungus did not grow, at least to a visible form, on the wood but grew abundantly on the uncovered inner bark surface and on other areas of uncovered wood.

Several factors seemed to be influential in determining the occurrence of mycelial mats and the longevity of inocula in nature. Weather conditions affected hoth the development and decline of the fungus. Mat production on individual trees seemed to be accelerated following periods of cool, rainy weather. Macroscopic growth of the fungus continued over a longer period of time during the winter months than during the summer, and apparently low winter temperatures, along with a minimum of insect activity, increased the longevity of the fungus mats. That the occurrence of new mats in July was rare was due probably to high temperatures plus the fact that wilt-killed trees were, by that time, nearing a state of deterioration which favored the growth of various wood-rotting fungi other than Endoconidiophora fagacearum. Observations have shown that new mats are seldom found during August in Illinois. 
Apparent ${ }^{1} y$ the freezing of mats during the winter does not in itself have a marked deteriorating effect on the fungus in nature. Laboratory tests showed that a temperature of 0 degrees $C$. favored longevity of the fungus in both humid and dry atmospheres; a continuous dry atmosphere was more favorable to the fungus than a continuous humid atmosphere. In the field, the fluctuating temperature and moisture conditions, combined with the effects of mat-invading microorganisms, may account in part for the fact that the germinability of spores collected during the winter months was lower than that of spores collected in spring and early summer. Also, during the winter months, fewer new mats form than in spring and early summer, and it was found that spores from new or immature mats were more highly viable than those from older mats. Perithecia occurred most abundantly on aging mats at temperatures of about 16 degrees $\mathrm{C}$. This was the average temperature for the five study areas in May, 1953, the month during which the greatest number of perithecia occurred.

The data obtained in this study indicate that the greatest inoculum potential of the oak wilt disease may be expected to occur in Illinois during April, May, and June. This indication is made clear by the following facts: (1) The greatest number of mats was found in May and June, (2) more viable conidia were present on mat samples taken in April than in other months, (3) the average size of mats that developed was greater in May and June than in other months, (4) the largest number of perithecia occurred on mats in May, (5) ascospores were most highly viable in April and May, (6) pad cells from immature mats were most highly viable and more mats of this class were found in March, April, and May than in other months. It is also interesting to note, from the standpoint of possible transmission, that insect activity was greatest on mats during April, May, and June.

Insects, particularly the Nitidulidae, in addition to being possible disease vectors and spermatizers of mycelial inats, are probably the most potent destroyers of naturally occurring oak wilt inocula. The feeding of squirrels on mycelial pads appears to be of minor significance in reduc- ing the amount of inoculum on trees, but the possibility of their spreading conidia, ascospores, or pad cells to healthy trees is evident.

The perpetuation of the oak wilt disease seems to be dependent not on the ability of the fruiting mats of the fungus to survive long periods of adverse conditions but rather on the continued existence of the fungus in an oak wilt area where new inocula are produced from time to time. As some trees cease to produce mycelial mats, other trees, more recently wilted, continue the process. Thus, an almost constant supply of fresh inoculum is present. To control the spread of such a disease beyond root-graft distances, it would seem necessary either to prevent the macroscopic fruiting of the fungus, particularly during March, April, May, and June, or to prevent the feeding of insects and other possible vectors on the mycelial mats on both standing and felled trees. The possibility of the extensive spread of the oak wilt disease from fungus development on bark or wood chips on the forest floor seems negligible and might be eliminated altogether by placing the pieces so that they dry rapidly.

\section{SUMMARY}

Need for information that wou!d be useful in explaining the spread of oak wilt prompted an intensive study of the availability of oak wilt inocula. This study was made in five major wilt areas in Illinois and covered the 10 -month period from October, 1952, through July, 1953.

Results of preliminary laboratory tests showed that a 2 per cent water agar medium and an incubation temperature of 28 degrees $\mathrm{C}$. for 36 hours were best for determining the germinability of both conidia and ascospores of the oak wilt fungus, Endoconidiophora fagacearum.

Good germination was obtained with cells from the interiors of pads of Endoconidiophora fagacearum mycelial mats that had not started to decline. Mycelial pad cells were found to have a slightly lower optimum temperature for germination than have conidia and ascospores. Germinated pad cells sporulated abundantly on water agar.

Formation of Endoconidiophora fagacearum perithecia on a wheat bran-agar 
medium was favored by temperatures of 16 and of 25 degrees $C$.

Tests in ritro showed that longevity of conidia of Endoconidiophora fagacearum was favored by low temperatures and a dry a tmosphere. Under conditions of high humidity, conidia on artificially grown mats remained viable for 102 days at 0 and at 12 degrees $\mathrm{C}$. Under conditions of low humidity, conidia on similar mats were still viable after 250 day's at 0 , at 12. and at 16 degrees. Conidia on a mat taken from nature and subjected to dry storage at 16 degrees were still viable after 330 days.

Laboratory feeding tests revealed that insects of the family Nitidulidae were effective destroyers of mats of the oak wilt fungus.

The rate at which wilt-infected oaks declined and the length of time required for trees to reach a condition favorable for the development of mycelial mats were found to be closely related to the time of incipient wilt.

The influence of monthly temperature and precipitation on formation of mats of the oak wilt fungus was suggested by accelerated mat development during April, May, and June. The average temperatures for May and June were near the optimum temperature for growth of the fungus.

The development of macroscopic mycelial growth of Endoconidiophora fagacearum was readily induced during March, April, and May simply by making cuts through the bark of trees that were nearing the mat-producing stage. This experience suggests a strong air relationship in mat formation.

In March and April, padless mats of the oak wilt fungus formed and grew on 17 of 213 pieces of bark that were taken from diseased oaks and placed on the forest floor. No macroscopic growth formed on any of 128 wood pieces that were treated in the same manner.

The time required for fungus mats on trees to progress from an immature stage to a deteriorated condition varied according to the season in which the mats first appeared. Mats that first appeared during the spring and summer declined rapidly as compared with mats that first appeared during the autumn and winter.
Insect activity on mats in nature was greatest during April, May, and June, when more species of insects were found than in other months. Members of the families Nitidulidae, Staphylinidae, and Histeridae, and of the order Collembola were more abundant than others. Among other agents commonly associated with mycelial mats were nematodes, mites, bacteria, fungi of various kinds, and crustaceans.

A total of $6+9$ typical mycelial mats, each with a pad in the center, were found on 31 selected trees, some of the mats in each month of the 10 -month study period. Spore counts from mat samples indicated that the highest concentration of conidia on mats was reached in December, after which there was a steady decrease during a period of low winter and spring temperatures until April, when a sharp rise occurred with the rise in temperature. After April the number of conidia decreased rapidly until, in July, no conidia could be found on mats. In the laboratory, best germination was obtained from conidia that were collected in April and good germination from those collected in October, November, and March. The highest average number of conidia was obtained from mature mats but the highest germination rate of conidia was obtained from immature mats.

The significance of mat size, as well as numbers of mats, in accounting for the concentration of conidia in an oak wilt area was demonstrated from sample data. A mat that measured 24 by $10 \mathrm{~cm}$. was estimated to contain $1,650,000,000 \mathrm{co}$ nidia.

Twenty-three per cent of 393 mats (which were presumed to be old enough to have perithecia) contained perithecia. Mats with perithecia were found in all months of the study except July, and the highest average number of perithecia per mat sample was found on aging mats in May. The best germination rate was obtained with ascospores collected from aging mats in April.

Mass transfers of cells from the interior portions of 423 mycelial pads to potato dextrose agar showed that cells from immature, mature, and aging mats were viable; 82 per cent of the pads from immature mats gave positive cultures. 


\section{$L I T E R A T U R E$ CI T E D}

Anderson, A. L., B. W. Henry, and T. L. Morgan

1948. The effect of temperature and relative humidity upon the viability of the conidia of Piricularia oryzae. (Abs.) Phytopathology $38(7): 574$.

Anderson, P. J., and W. H. Rankin

1914. Endothia canker of chestnut. Cornell Univ. Ag. Exp. Sta. Bul. 347:531-619.

Anonymous

1942. Oak wilt a fungus disease. Wis. Ag. Exp. Sta. Bul. 455. Pt. II. 58th Ann. Rep. 75-6.

1950. Industry fights oak wilt. Am. Forests 56(5):39.

Barnett, H. L., and V. G. Lilly

1952. Physiological factors affecting growth and sporulation of Chalara quercina in culture. (Abs.) Phytopathology $42(1): 2$.

Barnett, H. L., John M. Staley, and R. P. True

1952. Mycelial mats of Chalara quercina on killed oak trees as a potential source of perithecia in nature. Phytopathology 42(10):531-2.

Bretz, T. W.

1949. The present known distribution of oak wilt in Missouri. U. S. Dept. Ag. Plant Dis. Reptr. 33(11):437-8.

1951. A preliminary report on the perithecial stage of Chalara quercina Henry. U. S. Dept. Ag. Plant Dis. Reptr. $35(7): 298-9$.

1952a. New hosts for the oak wilt fungus, Chalara quercina Henry. (Abs.) Phytopathology $42(1): 3$.

$1952 b$. The ascigerous stage of the oak wilt fungus. Phytopathology $42(8): 435-7$.

Bretz, T. W., and W. G. Long

1950. Oak wilt fungus isolated from Chinese chestnut. U. S. Dept. Ag. Plant Dis. Reptr. $34(10): 291$.

Bretz, T. W., and David W. Morison

1953. Effect of time and temperature on isolation of the oak wilt fungus from infected twig samples. U. S. Dept. Ag. Plant Dis. Reptr. 37(3):162.

Campbell, R. N., and D. W. French

1953. Mycelial mats of oak wilt found in Minnesota during dry weather. U. S. Dept. Ag. Plant Dis. Reptr. $37(4): 243$.

Carter, J. C.

1950a. Oak wilt in Illinois. U. S. Dept. Ag. Plant Dis. Reptr. 34(3):81-2.

$1950 \mathrm{~b}$. Status of oak wilt and elm phloem necrosis in the Midwest. Arborist's News $15(5): 45-51$.

1952. Distribution and spread of oak wilt in Illinois. U. S. Dept. Ag. Plant Dis. Reptr. $36(1): 26-7$.

Craighead, Frank C., and Caleb L. Morris

1952. A progress report-: Possible importance of insects in transmission of oak wilt. Pa. Forests and Waters $4(6): 126-9$.

Cummins, George B.

1949. Oak wilt in Indiana. U. S. Dept. Ag. Plant Dis. Reptr. 33(8):332.

Curl, E. A.

1953. Studies on the availability of oak wilt inoculum in Illinois. (Abs.) Phytopathology $43(9): 469$.

Curl, E. A., G. J. Stessel, and Bert M. Zuckerman

1952. Macroscopic growth of the oak wilt fungus in nature. (Abs.) Phytopathology $42(1): 6$.

1953. Subcortical mycelial mats and perithecia of the oak wilt fungus in nature. Phytopathology $43(2): 61-4$.

Dietz, S. M., and J. W. Barrett

1946. Spread and control of oak wilt. (Abs.) Phytopathology 36(5):397.

Dietz, S. M., and Roy A. Young

1948. Oak wilt-a serious disease in Iowa. Iowa Ag. Exp. Sta. Bul. P91. 20 pp.

Dorsey, C. K., F. F. Jewell, J. G. Leach, and R. P. True

1953. Experimental transmission of oak wilt by four species of Nitidulidae. U. S. Dept. Ag. Plant Dis. Reptr. 37(8):419-20.

Elmer, O. H., I. J. Shields, and C. T. Rogerson

1953. Oak wilt in seven Kansas counties. U. S. Dept. Ag. Plant Dis. Reptr. 37(1):44.

Ernst, Raymond A., and T. W. Bretz

1953. American chestnut susceptible to oak wilt fungus. U. S. Dept. Ag. Plant Dis. Reptr. $37(3): 163$

Fergus, Charles L.

1953. Mycelial mats of the oak wilt fungus. Pa. State Col. Ag. Exp. Sta. Prog. Rep. 100. 7 pp. 
Fergus, Charles L., and C. 1. Morris

1950. Oak wilt in Pennsylvania. U. S. Dept. Ag. Plant Dis. Reptr. 34(10):291.

Finlay, Margaret Curtin

1950. The inighty oaks. Am. Forests $56(4): 7-9$.

Fowler, Marvin E.

1951. Surveys for oak wilt. U. S. Dept. Ag. Plant Dis. Reptr. 35(2) :112-8.

1952. Oak wilt surveys in 1951. U. S. Dept. Ag. Plant Dis. Reptr. 36(4):162-5.

1953. Oak wilt: its destruction and control. U. S. Dept. Ag. Plant Dis. Reptr. 37(2):10t-9.

French, David W., and Clyde M. Christensen

1950. Oak wilt in Minnesota. U. S. Dept. Ag. Plant Dis. Reptr. 34(3):82.

Gottlieb, David

1950. The physiology of spore germination in fungi. Bot. Rev. 16(5):229-57.

Gravatt, G. F., and R. P. Marshall

1917. Arthropods and gastropods as carriers of Cronartium ribicola in greenhouses. Phytopathology $7(5): 368-73$.

Griswald, C. L., and R. B. Neiswander

1953. Possible insect vectors of oak wilt. Trees $13(t): 18,22$.

Hawker, L. E.

1950. Physiology of fungi. University of London Press, Ltd., Bickley, Kent, England. 360 pp.

Heald, F. D., and M. W. Gardner

1914. Longevity of pycnospores of the chestnut blight fungus in soil. Jour. Ag. Res. $2: 67-75$.

Heald. F. D., and R. A. Studhalter

1914. Birds as carriers of the chestnut blight fungus. Jour. Ag. Res. 2:405-22.

1915. Longevity of pycnospores and ascospores of Endothia parasitica under artificial conditions. Phytopathology $5(1): 35-45$.

Henry, Berch W.

19tt. Chalara quercina n. sp., the cause of oak wilt. Phytopathology 34(7):631-5.

Henry, Berch W., and C. S. Moses

1943. An undescribed disease causing rapid dying of oak trees. Arborist's News $8(6):+6$.

Henry, Berch W., C. S. Moses, C. Audrey Richards, and A. J. Riker

194t. Oak wilt: Its significance, symptoms, and cause. Phytopathology 34(7):636-47.

Henry, Berch W., and A. J. Riker

1947. Wound infection of oak trees with Chalara quercina and its distribution within the host. Phytopathology $37(10): 735-43$.

Himelick, Eugene B., Richard D. Schein, and E. A. Curl

1953. Rodent feeding on mycelial pads of the oak wilt fungus. U. S. Dept. Ag. Plant Dis. Reptr. $37(2): 101-3$.

Hoffman, Paul

1952. Early trials in oak wilt chemotherapy. (Abs.) Phytopathology 42(1):11.

Jewell, Frederick F.

1953. Ascospore longevity of the oak wilt fungus as affected by temperature and humidity. (Abs.) Phytopathology $43(9): 476$.

King, D. B., and R. K. Winters

1952. Forest resources and industries of Illinois. Ill. Ag. Exp. Sta. Bul. 562. 95 pp.

Kuntz, J. E., and A. J. Riker

1950a. Root grafts as a possible means for local transmission of oak wilt. (Abs.) Phytopathology $40(1): 16-7$. 1950b. Oak wilt in Wisconsin. Wis. Ag. Exp. Sta. Stencil Bul. 9:1-9.

Leach. J. G., R. P. True, and C. K. Dorsey

1952. A mechanism for liberation of spores from beneath the bark and for diploidization of Chalara quercina. Phytopathology $42(10): 537-40$.

Lilly, Virgil Greene, and Horace L. Barnett

1951. Physiology of the fungi. McGraw-Hill Book Company, Inc., New York. +64 pp.

Ling, Lee

1945. Epidemiology studies on stripe rust of wheat in Chengtu Plain, China. Phytopathology $35(10): 885-94$.

McCrea, Adelia

1931. Longevity of conidia of common fungi under laboratory conditions. Mich. Acad. Sci., Arts, and Letters Papers 13:165-7.

Mclaughlin, W. D., and R. P. True

1952. The effects of temperature and humidity on the longevity of conidia of Chalara quercina. (Abs.) Phytopathology $42(9):+70$.

McNew, George I.. and Roy A. Young

1948. The nature and control of oak wilt. Natl. Shade Tree Conf. Proc. 24:123-30. 
Morris, C. L., and C. L. Fergus

1952. Observations on the production of mycelial mats of the oak wilt fungus in Pennsylvania. Phytopathology $42(12): 681-2$.

Norris, Dale M.

1953. Insect transmission of oak wilt in Iowa. U. S. Dept. Ag. Plant. Dis. Reptr. $37(8):+17-8$.

Riker, A. J.

1948. The menace of oak wilt. Arborist's News $13(7): 53-5$.

Rosen. H. R., and L. M. Weetman

19+0. Longevity of urediospores of crown rust of oats. Ark. Ag. Exp. Sta. Bul. 391.20 pp.

Staley, J. M., and R. P. True

1952. The formation of perithecia of Chalara quercina in nature in West Virginia. Phytopathology $42(12): 691-3$.

Stessel, G. J., and Bert M. Zuckerman

1953. The perithecial stage of Chalara quercina in nature. Phytopathology $43(2): 65-70$.

Strong, F. C.

1951. Oak wilt found in Michigan. U. S. Dept. Ag. Plant Dis. Reptr. 35(8):383.

Talbot, P. H. B.

1952. Dispersal of fungus spores by small animals inhabiting wood and bark. British Mycological Society Transactions $35: 123$.

True, R. P., J. M. Staley, J. G. Leach, H. L. Barnett, and C. K. Dorsey

1952. Liberation of spores from natural reservoirs facilitates overland spread of oak wilt. (Abs.) Phytopathology $42(9):+76$.

Wilkins, W. H.

1938. Studies in the genus Ustulina with special reference to parasitism. III. Spores-germination and infection. British Mycological Society Transactions 22:+7-83.

Wolf, Frederick A., and Frederick T. Wolf

19+7. The fungi. Vol. II. John Wiley and Sons, Inc., New York. 538 pp.

Wysong, Noel B.

1949. Rapid spread of oak wilt in the Midwest. Am. Nurseryman $90(10): 14,17,55-7$.

Young, Roy A.

1949. Studies on oak wilt, caused by Chalara quercina. Phytopathology $39(6): 425-41$.

Young, H. C., and G. J. Bart

1951. Oak wilt in Ohio. Aerial survey shows general infection in state's timber area. Ohio Farm and Home Res. 36(272):67-8, 71 .

Young, H. C., and Oren Spilker

1952. Longevity of disease organism getting attention in oak wilt project. Ohio Farm and Home Res. $37(279): 97-8$.

Young, H. C., G. J. Bart, Oren Spilker, W. H. Brandt, and R. B. Redet

1953. Progress of oak wilt investigations in Ohio. U. S. Dept. Ag. Plant Dis. Reptr. $37(4): 2+4$.

Zuckerman, Bert M., and E. A. Curl

1953. Proof that the fungus pads on oak-wilt killed trees are a growth form of Endoconidiophora fagacearum. Phytopathology 43(5):287-8. 




\section{SOME RECENT PUBLICATIONS}

\section{A.-ILLINOIS NATURAL HISTORY SURVEY BULLETIN.}

Volume 25, Article 1.-Characteristics of Residual Insecticides Toxic to the House Fly. Di IVillis N. Bruce. July, 1949. 32 pp., frontis. + 14 figs., bibliog.

Volume 25, Art cle 2.-Effect of Permanent Flooding in a River-Bottom Timber Area. B L L E. Yeager. August, 19+9. 34 pp., frontis. + 21 figs., bibliog.

Volume 25, Article 3.-Canada Geese of the Mississippi Flyway, with special reference to at Illinois flock. By Harold C. Hanson and Robert H. Smith. March, 1950. 14t pp., fralle + 82 figs., bibliog.

Volume 25, Article 4.-Biology of the White Crappie in Illinois. By Donald F. Hon-m August, 1951. 56 pp., frontis. + 13 figs., bibliog.

Volume 25, Article 5.-Commercial and Sport Fishes of the Mississippi River Between $\mathrm{A}$ ruthersville, Missouri, and Dubuque, lowa. By Paul G. Barnickol and William C. Stromit September, 1951. 84 pp., frontis. + 10 figs., bibliog.

Volume 25, Article 6.-Tularemia, Weather, and Rabbit Populations. By Ralph E. Yater and David H. Thompson. June, 1952. 32 pp., frontis. + 29 figs., bibliog.

Volume 26, Article 1.-The Mayflies, or Ephemeroptera, of Illinois. By B. D. Burks, Ma 1953. 216 pp., frontis. + 395 figs, bibliog. \$1.25.

Volume 26, Article 2.-Largemouth Bass in Ridge Lake, Coles County, Illinois. By Geuner W. Bennett. November, 1954. 60 pp., frontis. + 15 figs., bibliog.

\section{B.-ILLINOIS NATURAL HISTORY SURVEY CIRCULAR.}

32.-Pleasure With Plants. By L. R. Tehon. February, 1952. (Fourth printing, witb ovisions.) 32 pp., frontis. +9 figs.

38. -Windbreaks for Illinois Farmsteads. By J. E. Davis. February, 1954. (Fifth príti-i with revisions by L. B. Culver.) 34 pp., frontis. +27 figs.

39.- How to Collect and Preserve Insects. By H. H. Ross. June, 1953. (Fourth printiny, nul. alterations.) 59 pp., frontis. + 65 figs.

41.-How to Recognize and Control Termites in Illinois. By B. G. Berger. February, 14 if (Reprinted without text revision, April, 1950.) 44 pp., frontis. + 32 figs.

42.-Bird Dogs in Sport and Conservation. By Ralph E. Yeatter. December, 1948. $64 \mathrm{\sigma}$ frontis. +40 figs.

43.-Peach Insects of Illinois and Their Control. By Stewart C. Chandler. December, 15s 63 pp., frontis. +39 figs.

44.- The Drug Plants of Illinois. By Leo R. Tehon. July, 1951. 135 pp., frontis. +20 fe

45.-Housing for Wood Ducks. By Frank C. Bellrose. February, 1955. (Second primith with revisions.) 47 pp., illus., bibliog.

\section{C.-ILLINOIS NATURAL HISTORY SURVEY MANUAL.}

2.-Fieldbook of Illinois Land Snails. By Frank Collins Baker. August, 1939. 166 pp rviur frontis. +170 figs., 8 pls. $\$ 1.00$.

3.-Fieldbook of Native Illimois Shrubs. By Leo R. Tehon. December, 1942. 307 pp., 4 winr pls. +72 figs., glossary, index. $\$ 1.25$.

\section{List of arailable publications, about 101 titles, mailed on requeat.}

Single copies of Illinots Naturat. History SURvey publications for which no price is llanwill be furnished free of charge to individuals until the supply becomes low, after whit nominal charge may be made. More than one copy of any free publication may be otrin withnut cost by educational institutions and official organizations within the State of Ill prices to others on quantity orders of these publications will be quoted upon request.

\section{Address orders and correspondence to the Chief Illinois Natural. History Survey Natural Resources Building, Urbana, Illinois}

Payment in the form of money order or check made out to State Treasurer of Iilon Springfield, Illinois, must accompany requests for those publications on which a prick 